\title{
Incentives and behavior in markets
}

Citation for published version (APA):

Wolk, K. L. (2012). Incentives and behavior in markets. [Doctoral Thesis, Maastricht University]. Maastricht University. https://doi.org/10.26481/dis.20121114kw

Document status and date:

Published: 01/01/2012

DOI:

$10.26481 / \mathrm{dis} .20121114 \mathrm{kw}$

Document Version:

Publisher's PDF, also known as Version of record

\section{Please check the document version of this publication:}

- A submitted manuscript is the version of the article upon submission and before peer-review. There can be important differences between the submitted version and the official published version of record.

People interested in the research are advised to contact the author for the final version of the publication, or visit the DOI to the publisher's website.

- The final author version and the galley proof are versions of the publication after peer review.

- The final published version features the final layout of the paper including the volume, issue and page numbers.

Link to publication

\footnotetext{
General rights rights.

- You may freely distribute the URL identifying the publication in the public portal. please follow below link for the End User Agreement:

www.umlib.nl/taverne-license

Take down policy

If you believe that this document breaches copyright please contact us at:

repository@maastrichtuniversity.nl

providing details and we will investigate your claim.
}

Copyright and moral rights for the publications made accessible in the public portal are retained by the authors and/or other copyright owners and it is a condition of accessing publications that users recognise and abide by the legal requirements associated with these

- Users may download and print one copy of any publication from the public portal for the purpose of private study or research.

- You may not further distribute the material or use it for any profit-making activity or commercial gain

If the publication is distributed under the terms of Article $25 \mathrm{fa}$ of the Dutch Copyright Act, indicated by the "Taverne" license above, 


\section{Incentives and Behavior in Markets}


Incentives and Behavior in Markets

(C) 2012 Leonard Wolk

All rights reserved. No part of this publication may be reproduced, stored in a retrieval system, or transmitted, in any form, or by any means, electronic, mechanical, photocopying, recording or otherwise, without the prior permission in writing from the author.

ISBN 978-90-9027140-8 


\section{Incentives and Behavior in Markets}

\section{Proefschrift}

ter verkrijging van de graad van doctor

aan de Universiteit Maastricht, op gezag van Rector Magnificus,

Prof. dr. L.L.G. Soete,

volgens het besluit van het College van Decanen, in het openbaar te verdedigen

op woensdag 14 november 2012 om 12:00 uur

door

Kjell Leonard Wolk 


\section{Promotor}

Prof. dr. R. Bauer

\section{Copromotor}

Dr. R. A. J. Pownall

\section{Beoordelingscommissie}

Prof. dr. P. M. A. Eichholtz (vorzitter)

Prof. dr. C. N. Noussair (Tilburg University)

Prof. dr. A. Riedl

Dit onderzoek werd financieel mogelijk gemaakt door Maastricht Research School of Economics of Technology and Organizations (METEOR). 


\section{Contents}

Contents

$\begin{array}{ll}\text { Preface } & \text { iii }\end{array}$

1 Introduction 1

2 The charity as a firm 5

2.1 Introduction . . . . . . . . . . . . . . . 5

2.2 Data . . . . . . . . . . . . . . . . 10

2.3 Empirical study . . . . . . . . . . . . . . . . 11

2.4 Discussion and conclusion . . . . . . . . . . . . . . 21

2.5 Appendix: Classes and categories ............ . 23

3 Learning in internet auctions 25

3.1 Introduction . . . . . . . . . . . . . . 25

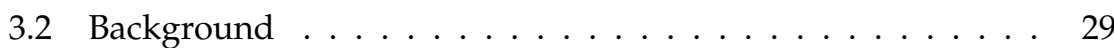

3.3 Empirical study . . . . . . . . . . . . . . . . . . . . 31

3.4 Discussion and conclusion . . . . . . . . . . . . . . 42

3.5 Appendix ...................... 44

4 Private and common values in art auctions 45

4.1 Introduction . . . . . . . . . . . . . . . . . . . 45

4.2 The value of art . . . . . . . . . . . . . . . . . . . 47

4.3 Data ......................... 51

4.4 Results ...................... 56

4.5 Discussion ..................... 60

4.6 Appendix: Artists . . . . . . . . . . . . . . . . . . 64

4.7 Appendix: Construction of variables . . . . . . . . . . . . 64

5 Incentives in prediction markets $\quad 67$

5.1 Introduction . . . . . . . . . . . . . . . 67

5.2 Data . . . . . . . . . . . . . . . . . . 69

5.3 Empirical study . . . . . . . . . . . . . . . 72

5.4 Discussion and conclusion . . . . . . . . . . . . 74 
$\begin{array}{lll}6 & \text { Conclusion } & 77\end{array}$

$\begin{array}{ll}\text { References } & 79\end{array}$

$\begin{array}{lr}\text { Nederlandse samenvatting } & 87\end{array}$

$\begin{array}{lr}\text { Biography } & 89\end{array}$ 


\section{Preface}

Often, I am asked to describe what I am working on. This question has become more and more difficult to answer as I got closer to finishing this dissertation. Most graduate students spend their time digging into the details of a predefined topic. As I often do, I did the reverse and the following quote from Paul Graham (2004, p. 26) describes it better than I can.

Scientists start out doing work that's perfect [...]. Eventually, they get to the point where they can do original work. Whereas hackers, from the start, are doing original work; it's just very bad. So hackers start original, and get good, and scientists start good, and get original.

For good and bad, I start original. I began this work by studying art markets, which soon became internet auctions and after that, I spent considerable time studying the charity sector. I am therefore deeply in debt to my supervisor, Rachel Pownall. You had to put up with my sometimes endless new ideas that I often spent considerable mental capacity thinking about. I do not think I could have finished this dissertation without your flexibility and your guidance which kept me on track.

Neither would I have written this thesis had it not been for Ronald Peeters, who toward the end of my master's recommended me to pursue a doctorate degree when I merely suggested to stay on as a student. I am very glad that I pursued this path. Thank you for your invaluable advice throughout the process.

While not directly involved in my thesis, Rob Bauer provided supporting advice and guidance throughout the process of writing this dissertation. I also learned a lot through our collaboration on the individual investor project together with Paul Smeets. I am especially grateful to Paul for our 
scientific discussions both at, and outside of, work. They were of great value and I hope we will sustain these over the coming years in Maastricht.

I also had the opportunity to work together with Dakshina G. De Silva. You have taught me invaluable lessons about academia and research. I truly enjoyed visiting you in Texas and I am looking forward to our continued collaboration.

I would like to thank Arno Riedl, Piet Eichholtz and Charles Noussair for serving on my evaluation committee. You provided me with very helpful feedback on my dissertation.

I also thank John Quigley for inviting me to spend a semester at the University of California, Berkeley, during which I benefited from many discussions both at and outside of the university. I am especially grateful to Karl Persson and Bryan Cockrell for all our discussions and our shared interest in movies and culture.

My most valuable experiences came from my frequent talks with Sajid, Aleksandar, Gildas, and Matteo with whom I at different points in time shared office. Sajid and Aleksandar, our discussions led to many valuable insights for life. Gildas, our many late evening talks were invaluable. Matteo, your idealism taught me some realism! Thank you all for the time we spent working and procrastinating in and around 'the office'.

I also thank all my colleagues with whom I have enjoyed the last years. In specific, and in (almost) random order: Oana, Andrea, Lei, Rogier, Gaby, Michael, Katie, Mukul, Sally, Paulo and Erkan.

The remainder of this book is the result of four invaluable years during which I forged many unique friendships and took part in discussions that reshaped my beliefs about our society and the world. I am deeply indebted to all of you for this. 


\section{Chapter 1}

\section{Introduction}

Incentives shape behavior in society and are used to align interests between different market participants. By designing proper contracts or setting up market institutions to induce a certain behavior, operators of markets can steer participants' behavior. A well known illustration of this principle is the relationship between an employer and an employee. Formally, this relationship is known as a principal-agent problem in the presence of moral hazard. Holmstrom (1979) shows that by properly designing wage contracts using a variable pay scheme, an employer can increase the productivity of an employee.

However, incentives do not only induce individuals to act in a desired way. They can also have adverse effects on behavior, and thereby markets, by for instance crowding out intrinsic motivation for otherwise welfare enhancing actions. For instance, Frey and Oberholzer-Gee (1997) show that, by offering a reward for having a nuclear waste repository built in the community of the respondents, the proportion of positive responses reduces by half compared to the situation when no reward is offered for it. The argument laid forward is that introducing an extrinsic incentive may crowd out intrinsic motivation for participation. These two effects thus have opposite influences on the overall participation rate.

Not only can incentives crowd out intrinsic motivation, but they can actually encourage negative actions. For instance, Gneezy and Rustichini (2000) show that when assigning a fine to an otherwise immoral action, this action becomes priced and is no longer judged as immoral to the same extent. The price thereby induces the opposite behavior one would expect following the introduction of an incentive. Similarly, during the re- 
cent financial crisis it has been questioned whether managerial incentives correctly align behavior with the interests of shareholders. For instance, Fahlenbrach and Stulz (2011) show that banks with CEO incentives that are better aligned do not perform better than banks with less well aligned incentives. This casts doubt on the effectiveness of economic incentives.

Overall, it is not enough to design incentives in order to create well functioning markets. We also need to study market participants' behavior in order to understand how markets function in conjunction with incentives. In this dissertation, we therefore ask the following questions: How do incentives affect behavior?, How is behavior shaped over time?, and How do external factors, independent of incentives, affect market behavior? To answer these questions, we present four empirical studies which are summarized below. The first and last study of the dissertation deal primarily with incentives, whereas the second and third study investigate auction participants' behavior.

The first study, chapter two, studies the effects of charity characteristics and underlying incentives on their cost-effectiveness using a panel of UK charities. Specifically, we study how the funding structure, representing incentives, of a charity influences its fundraising behavior. We disentangle the different types of funds and identify them as either restricted or unrestricted. Unrestricted funds can be spent freely by the charity, in contrast to restricted funds, which can only be spent on projects that fulfill specific requirements. If funds are largely restricted in their use, it is unlikely that the charity can spend the funds on risky projects or on projects to their own benefit.

We show that changes in the funding structure significantly alter charity behavior. This result lends partial support to the existence of asymmetric information between the charity and the donor and, in turn, implies that the decision whether or not to restrict the funds has important consequences for charity operations. It is crucial to understand these dynamics in order to determine how to efficiently regulate and govern the non-profit industry.

Chapter three looks at individual behavior in internet auctions. Specifically, we study the role of experience in internet art auctions by analyzing repeated bidding by the same bidder in a unique longitudinal field dataset. If experience plays a significant role in shaping bidding behavior, it can have a large impact on the design of auction markets. For instance, DellaV- 
igna and Malmendier (2004) show that firms need to respond to consumers making biased decisions in order to maximize revenues. Similarly, Simonsohn and Ariely (2008) show that eBay bidders herd into auctions that have already attracted existing bids and thereby pay higher prices than if they entered auctions with fewer existing bids. We find that bidders adapt their bidding strategies over time. Our evidence is consistent with bidders learning to take the value of participating in future auctions into account when submitting bids.

Chapter four examines the valuation and hence auction prices for art in London. The value of art is determined, on the one hand, by its future resale value and, on the other hand, by the emotional utility derived from owning the object. For art traded at an auction both components play important roles. Interestingly, these two components have very different characteristics from an auction theory point of view. The investment value will at any point in time and for a fixed horizon, be identical for all bidders, even though they have different information about it. This resembles a common value good, where every bidder only receives a noisy signal of the true value of the good. In contrast, emotional utility is strictly personal. The value someone derives from viewing a painting is independent from that of all other bidders. Thus, emotional value represents a private value good. We proxy for the variation in emotional value using the variation in mood that arises due to changes in the amount of sunshine and rainfall.

Our research suggests that there are important insights from understanding the role of emotions in auctions. The implications of our results are important to art auction participants. By inferring the nature of the good being sold, bidders can make informed judgments about the value that they attach to an item. Our findings highlight this fact and suggests that it may play an important role in assessing the investment value of paintings.

In chapter five we study the importance of monetary incentives in prediction markets. Prediction markets enable market based forecasting of future events. With the use of a double auction, public information is absorbed into market prices that directly translate into probabilities of future events occurring. The importance of monetary incentives on the aggregation of the traders' beliefs is not yet well understood. In particular, we study the co-movement between prediction markets based on real- and play-money that were run simultaneously. We exploit the fact that the play- 
money market was set up to constantly mimic the price of the real-money market and test whether or not, despite the imposed price reversion toward the real-money market, the markets co-move.

We find that $20 \%$ of the contract pairs with non-stationary price series do not co-move. This means that for these contracts the play-money market absorbs information from the public systematically differently in comparison to the real-money market. This evidence is significant in the light of the price manipulation scheme set up to synchronize the two markets. For the remaining $80 \%$ of the contract pairs, we cannot reject the hypothesis that the price series co-move.

In chapter six, we conclude the dissertation and provide an overview of insights and implications of the research presented herein. 


\section{Chapter 2}

\section{The charity as a firm}

\subsection{Introduction ${ }^{1}$}

Charitable organizations play a significant role in facilitating wealth redistribution. In 2011, 58\% of all individuals in the United Kingdom gave in total $£ 11$ billion to charity (Charities Aid Foundation, 2011). ${ }^{2}$ The total size of the UK charitable sector in 2010 amounted to $£ 30$ billion that was collected by in total 162,415 charities. While the amount donated on the aggregate is large, the median individual gave $£ 11$ in the year 2010/2011 and only $7 \%$ of all individual donors give at least $£ 100$ per month. Overall, six out of every ten adults in the UK donate to charity and the time trend shows a slight but steady increase over time. Most donors donate using cash, but there is a steady increase in donations collected over the internet and almost $7 \%$ of all donors donate online (Charities Aid Foundation, 2011).

Most charities are small and only 883 charities report income above $£ 10$ million (Charity Commission, 2012). The charities operate with a wide variety of target groups, ranging from poverty relief to community development (see the appendix for a detailed list). Given the size and importance of the sector it is surprising that little is known about how charities are operated. In this paper, we try to bridge this gap. Understanding how a charity oper-

\footnotetext{
${ }^{1}$ We would like to thank the audience at EEA 2012 in Malaga, as well as Jim Andreoni, Rob Bauer, Piet Eichholtz, Dakshina De Silva, Charles Noussair, Ronald Peeters, Rachel Pownall, Arno Riedl, Nora Silver, and Kaj Thomsson for insightful discussions and helpful comments. Parts of this paper were written while the author was visiting UC Berkeley, whose hospitality is gratefully acknowledged.

${ }^{2}$ To put the amount of individual donations in the UK in perspective, individuals in the United States donated in total $\$ 212$ billion in 2010 (Giving USA, 2011). Scaling the figures by the number of inhabitants, it amounts to approximately $£ 177$ and $\$ 677$ per capita respectively.
} 
ates in relation to its environment can help enhance social welfare through improved management and regulation.

In specific, we study charity cost-effectiveness as the ratio between fund in and outflows. The proxy can be interpreted as the return on every British Pound (GBP) spent by the charity. We measure the funding structure of a charity as the ratio of unrestricted funds to the total amount of funds available to be spent by the charity. Unrestricted funds can be spent freely, in contrast to restricted funds, which can only be spent on projects that fulfill specific requirements as set out by a donor. These restrictions can vary substantially between different funds even within a charity. However, if funds are largely restricted in their use, it is unlikely that trustees can spend the funds on risky projects or on projects to their own benefit.

The charity accounting regulation in the UK defines restricted funds as follows Charity Commission (2005, p. 95),

"Restricted funds are funds subject to specific trusts, which may be declared by the donor(s) or with their authority (eg in a public appeal) or created through legal process, but still within the wider objects of the charity. Restricted funds may be restricted income funds, which are expendable at the discretion of the trustees in furtherance of some particular aspect(s) of the objects of the charity. Or they may be capital (ie. endowment) funds, where the assets are required to be invested, or retained for actual use, rather than expended."

In contrast, unrestricted funds can be disposed at the discretion of the trustees, as the following extract from Charity Commission (2005, p. 95) shows,

"Unrestricted funds are expendable at the discretion of the trustees in furtherance of the charity's objects. If part of an unrestricted fund is earmarked for a particular project it may be designated as a separate fund, but the designation has an administrative purpose only, and does not legally restrict the trustees' discretion to apply the fund."

A potential donor faces the decision to either invest time and resources in specifying proper restrictions or donate resources unrestricted to a charity that he believes will spend these resources well. For the donor to make 
an informed decision he thus needs to understand how his decision affects the cost-effectiveness of the charity. In the absence of traditional tools to alleviate moral hazard, such as variable pay, the donor only has one possibility to align the interests of the charity with his own. By restricting the funds he donates to the charity so that they only can be used for a specific purpose, he can impose control on the behavior of the charity. In this study, we empirically estimate the impact of such control measures on charity cost-effectiveness.

In particular, we investigate the relationship between the aggregate donor decision regarding the the charity's funding structure and its cost-effectiveness in a panel of charities between the fiscal years 2007 and 2009 in the United Kingdom (UK). In Figure 2.1, the proportion of unrestricted funds is plotted on the horizontal axis against the cumulative distribution of charities on the vertical axis. Even though almost $40 \%$ of all charities consists of unrestricted funds only, the plot shows significant variation across the whole range of possible structures. This suggests that charities do not strive for a single optimal structure, but that the desired structure varies by charity.

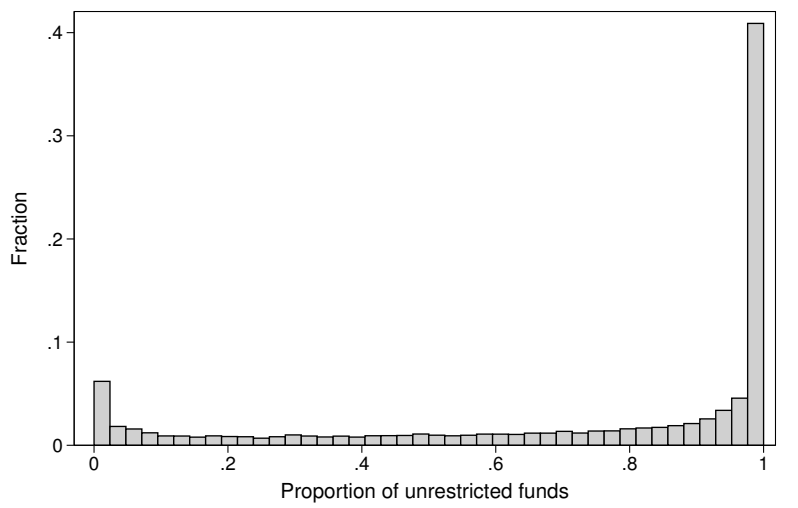

Figure 2.1: The cumulative distribution of funds of the charities in our sample. The horizontal axis represents the unrestricted funds as a proportion of total funds available to the charity. The vertical axis represent the frequency of charity-year observations of the pooled sample. It is clear from the figure that the majority of all charities consist of unrestricted funds only and only a small fraction is fully restricted by their donors.

We show that changes in the funding structure significantly affect changes in charity cost-effectiveness. An increase in the proportion of unrestricted funds contemporaneously reduces charity effectiveness. However, a lagged increase in this proportion improves effectiveness, suggesting that, in order 
to fully understand the response dynamics, it is necessary to study the time dimension of charity operations and we provide dynamic results for 2007 to 2009. Further, our study shows that several charity characteristics are correlated with cost-effectiveness, implying that the charity industry as a whole is highly heterogeneous. Our approach also addresses a frequently noted problem related to the study of charity operations: ${ }^{3}$ different programs, activities, and target areas require different expenses and thus, even though a charity would rank low due to high expenses, measuring its unobserved but 'true' impact instead might lead to a reversed ranking. As a partial solution to this problem, we look at charity cost-effectiveness and not cost alone.

Prior research on the management and operation of charities focuses on whether or not the managerial objectives of charities coincide with a net revenue maximizing strategy. Weisbrod and Dominguez (1986) introduce a measure for the price of giving, and relate this to the level of donations received. The price of giving measures the cost, in terms of administrative and fundraising expenditures, to every GBP donated to a charity. The authors show that charities are neither maximizing revenues (size), nor net revenues (output per GBP received). Further research confirms these findings on US data (Okten and Weisbrod, 2000; Tinkelman, 2004) as well as UK data (Posnett and Sandler, 1989; Khanna et al., 1995). This evidence sheds light on the problem that a donor faces when donating to a charity. If a charity does not act in the best interest of their donors and does not maximize the final output per GBP received, potential donors may refrain from donating and thus lower the overall influence of charity on society.

Apart from the literature on managerial fundraising strategies, research on charities mainly focuses on the following two research questions. The first stream of literature studies the reason behind charitable giving. Warr (1982) establishes a theoretical model of charitable giving as a public good, showing that the there is a complete crowding-out of individual giving under fiscal redistribution. Anderoni (1988) criticizes this approach and Ribar and Wilhelm (2002) show that preferences such as joy-of-giving appear to only have limited effectiveness. Instead, warm-glow giving is proposed as an alternative explanation (Anderoni, 1990). It motivates giving by assign-

\footnotetext{
${ }^{3}$ For example, see Dean Karlan's blog post "Why Ranking Charities by Administrative Expenses is a Bad Idea" at http://www.freakonomics.com/2011/06/09/why-ranking-charitiesby-administrative-expenses-is-a-bad-idea/ for a discussion of this issue. Also Andreoni and Payne (2011) briefly discuss this issue.
} 
ing utility to the act of giving itself. This can explain why, as the population grows, individuals still contribute to the social welfare by charitable giving. Warm-glow giving is also shown to work well experimentally (Palfrey and Prisbrey, 1997).

Second, a large stream of literature looks specifically at the role of the charity in charitable giving and how different ways to organize fundraising affect the level of donations. Following the theoretical foundations laid out in Andreoni (1998), several papers study different fundraising mechanisms. Landry et al. (2006) conduct a field study to compare the use of a lottery to voluntary contributions. In line with theoretical predictions, the authors find evidence that lotteries maximize contributions. Charity auctions have also received widespread attention, Carpenter et al. (2008) conduct a field study on using different auction formats for fundraising. The authors find that the first-price auction dominates both the second-price and the allpay auction. Karlan and List (2007) conduct a field experiment to study the price of giving by grant matching. The results show that once grants are matched, regardless of the matching ratio, the amount donated rises significantly. Interestingly, grant matching also increases the participation rate.

Anderoni and Payne (2003) and Andreoni and Payne (2011) deviate from the focus on donors and study behavioral changes due to variation in government grants. The authors show that charities respond to increases in government grants by reducing money spent on fundraising. Giving an additional dollar in grants, reduces the fundraising expenditures by 77 cents (Andreoni and Payne, 2011). This shows that charities respond to incentives that are externally imposed and suggests that it is important to understand how the regulatory environment of charities shapes their behavior.

This paper contributes to several streams of literature. First, it contributes to the growing literature that seeks to enhance our understanding the behavior of charities, pioneered by Anderoni and Payne (2003). Second, we contribute to the growing literature on moral hazard and executive compensation. This literature mainly focuses on managerial discretion, as proxied by managerial characteristics such as the share of ownership and years in office, (Berger et al., 1997), or on compensation structure (Agarwal et al., 2009). The share of unrestricted funds provides a different proxy for the level of managerial discretion and directly measures exogenous restric- 
tions on managerial behavior. However, there is one caveat to this analogy. If donors can screen charities and infer whether it is well or poorly governed, then it means that the funding structure is a response to the quality of trustees rather than a control mechanism of donors. Consequently, in equilibrium, there would be no, or only little, variation in cost-effectiveness.

The paper is structured as follows. Section two introduces the data and section three presents our empirical findings. Finally, section four discusses the results and concludes.

\subsection{Data}

We collect data from the Charity Commission in the UK. The data covers the fiscal years 2007 to 2009. The data includes a full set of accounting measures as well as several charity specific characteristics. We exclude all organizations representing consolidated accounts, and study individual charities only. As a limitation imposed by the UK Charity Commission, each charity is only observed if it has at least $£ 500000$ in income or total assets amounting to at least $£ 2.8$ million. Table 2.1 shows summary statistics of total assets, income, expenses and the different types of funds available to the charity per year. Over the sample period, the charities appear, on average, to shrink in size (measured by total assets). The average total income also shrinks, while expenses are stable over time. There is a small jump in the number of charities that fulfill the requirements between 2007 and 2008. From 2008 to 2009, the difference is smaller.

In this paper we focus on charitable income and expenses. There are two major accounts through which income is generated and through which costs are expended (Charity Commission, 2005):

\section{Charitable activities:}

Charitable activities include all activities that the charity performs in order to fulfill its objectives as a charity. On the expenditure side, it includes direct and indirect costs related to reaching its aim (Charity Commission, 2005, p. 28). This includes grants made, as well as costs and income associated with the activity.

\section{Generating funds:}

This category includes all income and expenditures that are not directly linked to the objectives of the charity. It accounts for the costs 


\begin{tabular}{|c|c|c|c|c|}
\hline & Total Assets & Total Inc. & Total exp. & $\begin{array}{r}\% \text { unrestr. } \\
\text { funds }\end{array}$ \\
\hline \multicolumn{5}{|l|}{2007 (5,983 obs) } \\
\hline $\max$ & $3,668,972,000$ & $540,950,000$ & $637,189,018$ & 1.000 \\
\hline mean & $8,136,833$ & $3,239,533$ & $2,889,182$ & 0.717 \\
\hline median & 723,069 & $1,191,377$ & $1,049,000$ & 0.913 \\
\hline $\min$ & 0 & 484,624 & 880 & 0.000 \\
\hline sd & $60,568,219$ & $12,530,803$ & $12,522,482$ & 0.348 \\
\hline \multicolumn{5}{|l|}{2008 (6,243 obs) } \\
\hline $\max$ & $3,575,325,290$ & $312,403,475$ & $323,689,189$ & 1.000 \\
\hline mean & $7,202,459$ & $3,013,251$ & $2,759,445$ & 0.723 \\
\hline median & 620,171 & $1,138,839$ & $1,016,347$ & 0.922 \\
\hline $\min$ & 0 & 561 & 440 & 0.000 \\
\hline sd & $55,819,209$ & $8,407,349$ & $8,371,481$ & 0.348 \\
\hline \multicolumn{5}{|l|}{$2009(6,378 \mathrm{obs})$} \\
\hline $\max$ & $2,707,456,522$ & $433,582,179$ & $452,251,346$ & 1.000 \\
\hline mean & $6,802,903$ & $2,980,775$ & $2,821,156$ & 0.725 \\
\hline median & 565,298 & $1,103,199$ & $1,016,609$ & 0.920 \\
\hline $\min$ & 0 & 28,636 & 656 & 0.000 \\
\hline sd & $47,665,036$ & $8,624,206$ & $9,606,808$ & 0.346 \\
\hline
\end{tabular}

Table 2.1: Summary statistics in British pounds by year (deflated to 2007 values). The statistics show that there is an increasing number of charities passing the sample threshold each year but that the mean and median size of the charities appear to shrink slightly.

and income related to voluntary contributions, as long as those are outside the scope of the main objective of the charity.

In Figure 2.2a, we plot the income over the different categories. There are additional sources of income that make up a small fraction of total income. We group those sources into 'other income'. It is clearly visible that income from charitable activities dominates, with income from generating activities being the second largest source. Other income appears to be only a minor source of income. We can compare these figures to the expenses incurred by the average charity. The division between the different costs is plotted in Figure 2.2b. Similarly to the division of income, charitable activities represent the biggest share of costs to running a charity, with fundraising, governance and other costs being much smaller.

\subsection{Empirical study}

\subsubsection{Charity characteristics}

Our main goal is to study how the funding structure of charities affects their cost-effectiveness. Prior studies on the role of fundraising on the amount of 
(a)

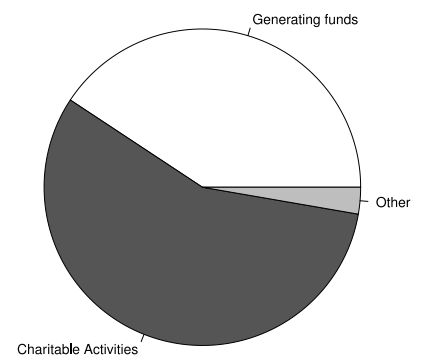

(b)

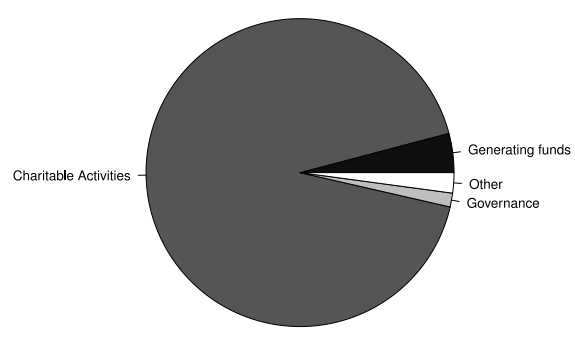

Figure 2.2: Categorical average shares of charity (a) income; and (b) expenditures. The income is split more evenly between generating funds and charitable activities than expenditures. This is mechanical since charitable activities carry a much larger cost of fundraising than the cost of generating funds which by definition consist to a large extent of voluntary contributions and similar sources of funds.

donations have constructed a price of giving as a measure of the fundraising elasticity. The measure denotes the cost to a donor of generating an additional GBP in output and Weisbrod and Dominguez (1986) define it as follows,

$$
P=\frac{1-T}{1-\frac{C_{F R}+C_{A}}{I_{D}}}
$$

where $T$ is the marginal tax rate. $C_{F R}$ and $C_{A d}$ denote the expenditures on fundraising and administration respectively. $I_{D}$ denotes the income from the associated donations. Variations on this measure have become the de facto standard in the literature (see for instance Tinkelman, 2004; Khanna et al., 1995; Okten and Weisbrod, 2000). In this paper we do not disentangle grants and the costs of making grants and therefore we adapt the price measure in Equation 2.1 to construct an overall cost-effectiveness measure as a ratio between income and costs. Our measure therefore captures the extent to which a charity withholds funds, either for later expeditures or for investing in assets. After aggregating different sources of income and 
expenditures the procedure results in the following measure,

$$
R=\frac{I}{C} \text {. }
$$

$I$ is the income from voluntary contributions, charitable activities and fundraising trading activities. $C$ are the associated costs with the addition of governance expenditures. While we observe several different accounts of income and expenditures, the reporting practice differs among different charities and, for instance, $1 \%$ of all charity-years in our sample report no expenditures on charitable activities, while as many as $52 \%$ charity-years report no costs to generating funds. On the income side, a significant portion of charity-years are reported without income due to charitable activities (28\%) or without including generating funds $(12 \%) .{ }^{4}$ To exclude the possibility that reporting practices drive our results, we study the aggregate level only.

There is significant variation in cost-effectiveness across different funding structures, which we show in a local regression using a weighting function to allow for a non-linear relationship in Figure 2.3. It is readily apparent that the higher and lower end of the proportion of unrestricted funds is associated with higher cost-effectiveness than those charities that have mixed funding structures. This suggests that several different 'types' of charities exist within the sample. The existence of different 'types' shows that there are low and high performing charities which indicates that there is heterogeneity in the effort exerted by the charities.

As frequently noted in the literature on charities (see, for instance Posnett and Sandler, 1989; Khanna et al., 1995; Okten and Weisbrod, 2000), the age of a charity serves as an important proxy for the quality of that charity. Consequently, in Figure 2.4, we plot the age against the proportion of unrestricted funds. We then divide the area into hexagonal bins and count the number of observations in each bin. The bins are colored according to the number of observations in each hexagon. Two immediate patterns appear in the figure. On the one hand, we see that as charities age there are less charities with a balanced funding structure as indicated by the large white area in the upper part of the figure. On the other hand, most charities move toward a fully unrestricted funding structure, with only a few moving to a fully restricted funding structure, as they age. One explanation for the pattern that we observe, is that when a charity is launched it relies primarily

\footnotetext{
${ }^{4}$ The variation in reporting practices is known in the literature, see for instance Tinkelman (2004).
} 
(a)

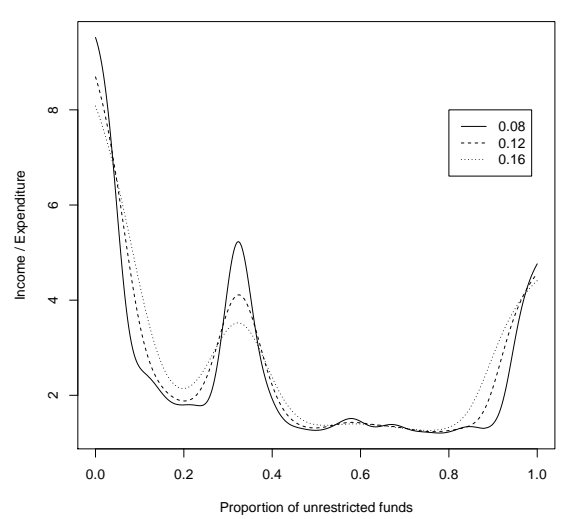

(b)

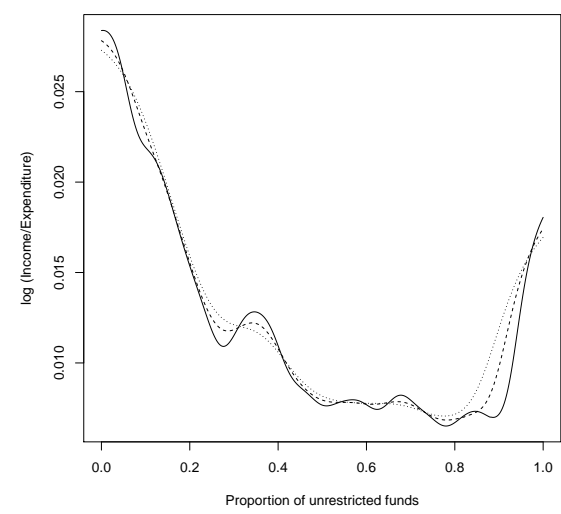

Figure 2.3: Charity cost-effectiveness compared to the proportion of unrestricted funds. In panel (a), cost-effectiveness is measured in levels, and in panel (b), We plot cost-effectiveness the same measure in logs. The panels show that there is a large heterogeneity in costeffectiveness between charities and it therefore appears as if donors are not able to screen charities on cost-effectiveness. This indicates that there are several different types of charities operating within the sample.

on restricted funding, and only as it ages it is able to attract unrestricted funds.

Given the descriptive evidence on the variation in cost-effectiveness with the proportion of unrestricted funds, as well as how age affects the funding structure, we estimate the following pooled regressions,

$$
R_{i}=\beta_{0}+\beta_{1} \text { Unrestricted }_{i}+\beta_{2} \text { Restricted }_{i}+\beta_{3} \text { Age }_{i}+X_{i}^{\prime} \gamma+\varepsilon_{i}
$$

where $R_{i}$, represents our cost-effectiveness proxy defined in this section. The dummy variable Unrestricted takes value one for all charities with a proportion of unrestricted funds equal to $100 \%$. Similarly, Restricted takes the value one when a charity consists of restricted funds only. Age is measured in years since the charities were founded until the beginning of 2011. The vector $X$ contains our control variables: age interacted with the funding structure dummies, total assets in million GBP as well as a set of type and class dummies that define the activity areas of the charities. The complete list of classes and types is presented in the appendix. The coefficients are estimated using a pooled OLS due to the fact that many of the covariates are time invariant. The standard errors are clustered on the charity level. 


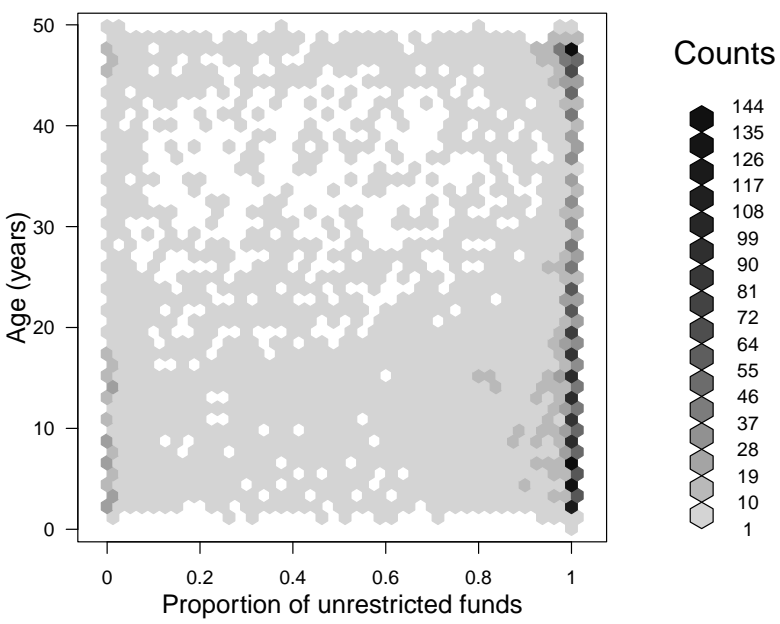

Figure 2.4: Charity age and funding structure. In this plot the color of each hexagon represents the number of charities that belong to it. The darker the color the more charities operate in a certain region of the plot. The plot shows that regardless of the age of the charity, most charities are unrestricted and it is only a few young charities that appear to be fully restricted. A few charities have mixed funding structures, but it appears that there is a convergence toward the extreme funding structures as charities age and only very few older charities operate with a mixed structure.

The regression results are presented in Table 2.2. In the first two columns we report results for the level of cost-effectiveness and in the remaining two columns we transform the proxy using the natural logarithm. The results show that unrestricted charities significantly outperform charities with mixed funding structures (the base category) by around nine pounds per pound spent. The fully restricted charities on the other hand do not significantly outperform the base category. Interestingly, when conducting an F-test for the difference between the coefficients of unrestricted and fully restricted, we cannot reject the null hypothesis of equality between the two. This suggests that charities at the extremes outperform those with mixed funding structures significantly.

The effect of age is similar throughout our different specifications and shows a significant negative effect, indicating that older charities are, on average, less productive. This is contrary to the literature (see for instance 


\begin{tabular}{|c|c|c|c|c|}
\hline & $\begin{array}{c}(1) \\
R\end{array}$ & $\begin{array}{c}(2) \\
R \\
\end{array}$ & $\begin{array}{c}(3) \\
\log R \\
\end{array}$ & $\begin{array}{c}(4) \\
\log R\end{array}$ \\
\hline Unrestricted & $\begin{array}{c}9.795^{* * *} \\
(2.698)\end{array}$ & $\begin{array}{c}8.508^{* * *} \\
(2.547)\end{array}$ & $\begin{array}{c}0.218^{* * *} \\
(0.037)\end{array}$ & $\begin{array}{c}0.204^{* * *} \\
(0.037)\end{array}$ \\
\hline Fully restricted & $\begin{array}{c}6.482 \\
(4.105)\end{array}$ & $\begin{array}{c}6.558 \\
(4.133)\end{array}$ & $\begin{array}{c}0.103 \\
(0.120)\end{array}$ & $\begin{array}{c}0.071 \\
(0.120)\end{array}$ \\
\hline Age & $\begin{array}{l}-0.089^{* * *} \\
(0.021)\end{array}$ & $\begin{array}{c}-0.095^{* * *} \\
(0.021)\end{array}$ & $\begin{array}{l}-0.008^{* * *} \\
(0.001)\end{array}$ & $\begin{array}{c}-0.008^{* * *} \\
(0.001)\end{array}$ \\
\hline Age $\times$ Unrestricted & $\begin{array}{c}-0.274^{* * *} \\
(0.082)\end{array}$ & $\begin{array}{c}-0.253^{* * *} \\
(0.079)\end{array}$ & $\begin{array}{c}-0.006^{* * *} \\
(0.002)\end{array}$ & $\begin{array}{c}-0.006^{* * *} \\
(0.002)\end{array}$ \\
\hline Age $\times$ Fully restricted & $\begin{array}{l}-0.201^{*} \\
(0.114)\end{array}$ & $\begin{array}{l}-0.234^{* *} \\
(0.118)\end{array}$ & $\begin{array}{l}-0.002 \\
(0.004)\end{array}$ & $\begin{array}{l}-0.001 \\
(0.004)\end{array}$ \\
\hline log Total assets (GBP million) & $\begin{array}{c}0.511^{* * *} \\
(0.109)\end{array}$ & $\begin{array}{l}0.202^{*} \\
(0.106)\end{array}$ & $\begin{array}{c}-0.012^{* * *} \\
(0.004)\end{array}$ & $\begin{array}{c}-0.018^{* * *} \\
(0.004)\end{array}$ \\
\hline Constant & $\begin{array}{c}5.625^{* * *} \\
(1.046)\end{array}$ & $\begin{array}{c}10.883^{* *} \\
(4.971)\end{array}$ & $\begin{array}{c}0.230^{* * *} \\
(0.026)\end{array}$ & $\begin{array}{l}0.306^{*} \\
(0.184)\end{array}$ \\
\hline Observations & 18,549 & 18,574 & 17,981 & 18,006 \\
\hline R-squared & 0.006 & 0.011 & 0.031 & 0.042 \\
\hline Type dummies & - & Yes & - & Yes \\
\hline Class dummies & Yes & - & Yes & - \\
\hline $\begin{array}{l}\text { F Test: Unrestricted - Fully res } \\
\text { P-value }\end{array}$ & $\begin{array}{c}\text { icted }=0 \\
0.501\end{array}$ & 0.687 & 0.356 & 0.286 \\
\hline
\end{tabular}

Table 2.2: Pooled regression of charity characteristics on cost-effectiveness. The table shows four specifications, in the first two specifications $R$ serves as the dependent variable. The coefficients of these regressions can be interpreted as the GBP return. The last two specifications are specified with the natural logarithm of $R$ as the dependent variable, and the coefficients represent percentage changes. Restricted and Unrestricted represent the extreme funding structures of either $0 \%$ or $100 \%$ unrestricted funds and the coefficients of these variables are estimated relative to the left out category of a mixed funding structure. There are two sets of additional control variables. In specification one and three we include class dummies which represent how many different types within each class a charity belongs to. In specification two and four, we include dummy variables for each individual type. See the appendix of this chapter for a detailed list.

Posnett and Sandler, 1989), which argues that age serves as a quality signal and should therefore correlate positively with cost-effectiveness. Interacting age with the level of restrictions also shows a slight negative effect. However, one caveat with our finding is that our sample only consists of the largest charities operating in the United Kingdom. These charities may be able to signal quality by their size and familiarity rather than age. Therefore, age may negatively impact cost-effectiveness due to large overhead costs stemming from inefficient organizational structures.

In addition to directly observable characteristics of charities, inter-charity relationships may also affect behavior. Consequently, we map the relationships between charities by matching the names of trustees across charities. 
In Figure 2.5, we plot the network of charities as connected by their trustees. The most striking finding is that a large fraction of all charities is unconnected (4 145 charities), with a minority being connected to at least one other charity (2 233 charities). The analysis in this section should be interpreted with some caution due to the fact that trustees are matched only on names and official titles, resulting in the possibility that two trustees with a common name and title might falsely be identified as a single trustee. ${ }^{5}$

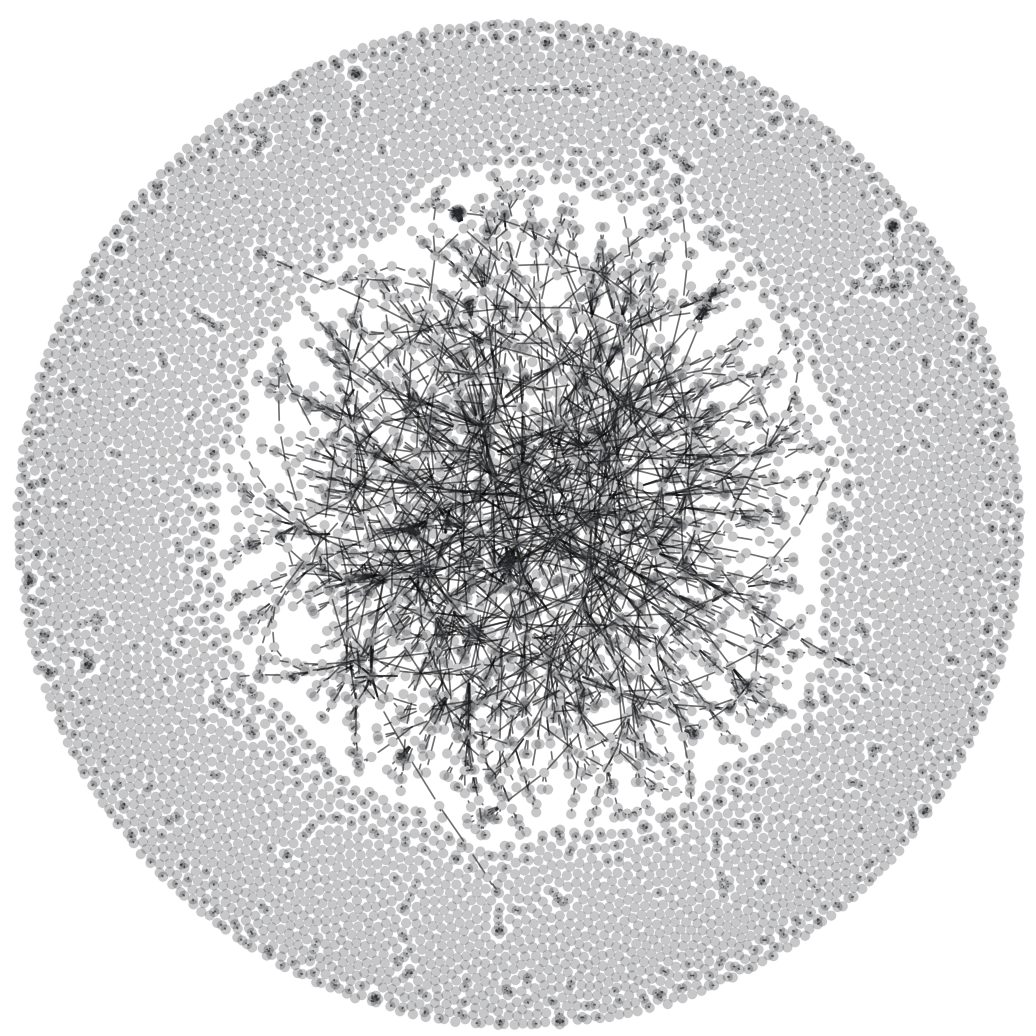

Figure 2.5: The network of charities for the financial year 2009. The large outer band of charities consist mainly of sparsely connected charities whereas those with most connections are plotted in the center.

\footnotetext{
${ }^{5}$ Titles specified in the data include among others Sir, Dr., and Hon.
} 
In Figure 2.6, we plot the degree distribution for the charities, which summarizes the connectivity of the charity network. The horizontal axis plots the log of the degree of connections and the vertical axis the log of the frequency for each degree. If the log-log plot reveals a linear relationship, the network follows a power law (Kolaczyk, 2009). A visual inspection of the plot reveals that it does not appear to fully follow a power law, which means that, as the size of the network grows, it will not retain its network properties.

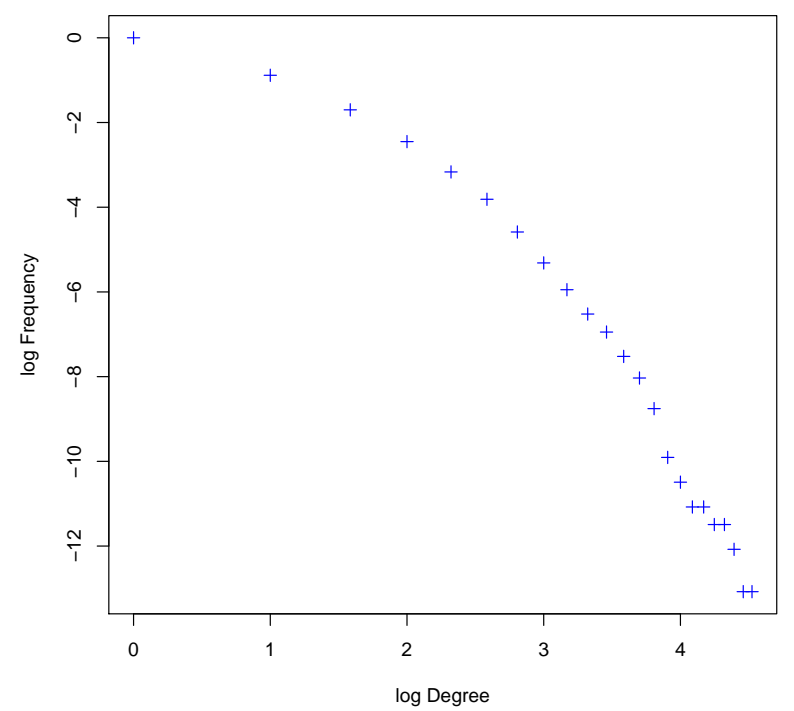

Figure 2.6: Degree distribution of the network of charities for the financial year 2009.

Next, we study charity connectedness and cost-effectiveness. Due to data limitations, we can only study the effect of connectedness on the crosssection from the year 2009. In order to partially correct for the possibility of overstating the number of connections, we use a binary indicator variable that captures whether the charity is connected to at least another charity via one or more of its trustees. The results are presented in Table 2.3. When we do not control for any charity characteristics, in specification (1), being connected negatively affects charity cost-effectiveness. This effect carries through also once we control for additional characteristics in specification (2) and (3). 


\begin{tabular}{|c|c|c|c|}
\hline & $\begin{array}{c}(1) \\
\log R\end{array}$ & $\begin{array}{c}(2) \\
\log R\end{array}$ & $\begin{array}{c}(3) \\
\log R\end{array}$ \\
\hline Connected & $\begin{array}{c}-0.166^{* * *} \\
(0.023)\end{array}$ & $\begin{array}{c}-0.091^{* * *} \\
(0.023)\end{array}$ & $\begin{array}{c}-0.074^{* * *} \\
(0.025)\end{array}$ \\
\hline Connected $\times$ Unrestricted & & & $\begin{array}{l}-0.055 \\
(0.054)\end{array}$ \\
\hline Connected $\times$ Fully restricted & & & $\begin{array}{c}-0.056 \\
(0.162)\end{array}$ \\
\hline Unrestricted & & & $\begin{array}{c}0.202^{* * *} \\
(0.055)\end{array}$ \\
\hline Fully restricted & & & $\begin{array}{c}0.221 \\
(0.154)\end{array}$ \\
\hline Age & & $\begin{array}{l}-0.009^{* * *} \\
(0.001)\end{array}$ & $\begin{array}{c}-0.006^{* * *} \\
(0.001)\end{array}$ \\
\hline Age $\times$ Unrestricted & & $\begin{array}{c}0.001 \\
(0.001)\end{array}$ & $\begin{array}{c}-0.005^{* *} \\
(0.002)\end{array}$ \\
\hline Age $\times$ Fully restricted & & $\begin{array}{l}-0.002 \\
(0.003)\end{array}$ & $\begin{array}{l}-0.008 \\
(0.006)\end{array}$ \\
\hline log Total assets (GBP million) & & $\begin{array}{c}-0.013^{* * *} \\
(0.005)\end{array}$ & $\begin{array}{c}-0.015^{* * *} \\
(0.005)\end{array}$ \\
\hline Constant & $\begin{array}{c}0.102^{* * *} \\
(0.014)\end{array}$ & $\begin{array}{c}0.296^{* * *} \\
(0.034)\end{array}$ & $\begin{array}{c}0.210^{* * *} \\
(0.034)\end{array}$ \\
\hline Observations & 6,188 & 6,181 & 6,181 \\
\hline R-squared & 0.008 & 0.032 & 0.035 \\
\hline Class dummies & - & Yes & Yes \\
\hline
\end{tabular}

Table 2.3: Pooled regression of charity connectedness on cost-effectiveness for the financial year 2009. The variable of interest is Connected which takes the value of one if at least one trustee of a charity is connected to at least one other charity. The results show that in all three specifications being connected to at least one other charity significantly lowers the charity effectiveness by between $7.4 \%$ and $16.6 \%$.

\subsubsection{Dynamic behavior}

We proceed by testing whether changes to the charity funding contract affect its behavior. Specifically, we test for incentive effects that arise from changes in the fund structure of a charity. We are particularly interested in the effect of $F_{i, t}$ on our cost-effectiveness ratio. $F_{i, t}$ defined as the proportion of unrestricted funds to the total amount of funds available and takes any value between, and including, zero and one. A change to the funding structure is equivalent to a change to the incentive contract in the charity. The individual donation decisions that together result in a fund structure for the charity are exogenous to the charity in the sense that there is no self-selection into a certain fund structure.

One problem often encountered in empirical studies of asymmetric in- 
formation is that one cannot disentangle unobserved heterogeneity from the incentive effects (Chiappori and Salanié, 2001). The problem is that the cross-sectional differences in cost-effectiveness identified previously could have been driven by agent heterogeneity or by differences in the contracts accepted by the agents. In order to distinguish between these two effects, we rely on repeated observations of each charity and can thus control for unobserved heterogeneity by estimating our model with charity fixed effects.

We follow the empirical literature that uses conditional correlations to test for moral hazard (Abbring et al., 2003; Chiappori and Salanié, 2001). This approach allows us to test the alternative hypothesis of moral hazard, with the drawback of not being able to distinguish between symmetric information and adverse selection under the null. The reason stems from the unobserved heterogeneity of the agents that could be correlated with the choice of funding structure, as studied in Section 2.3.1. If a change to the funding contract does not lead to an incentive effect, then it is possible that the trustees have self-selected into a particular charity due to their 'type', which is indistinguishable from symmetric information. Consequently, we analyze changes in the return to charity expenditures using the following fixed effects panel regressions,

$$
\begin{aligned}
& R_{i, t}=\beta_{0}+\beta_{1} F_{i, t}+X_{i, t}^{\prime} \gamma+c_{i}+\varepsilon_{i, t} \\
& R_{i, t}=\beta_{0}+\beta_{1} \text { Unrestricted }_{i, t}+\beta_{2} \text { Restricted }_{i, t}+X_{i, t}^{\prime} \gamma+c_{i}+\varepsilon_{i, t}
\end{aligned}
$$

where we are interested in the coefficient of $F_{i, t}$, the percentage change in the cost-effectiveness due to a $100 \%$ change in the proportion of unrestricted funds. The results are presented in Table 2.4. In all specifications we regress against the natural logarithm of our effectiveness proxy.

In Specifications (1) and (3), in Table 2.4, we look at the contemporaneous correlations. The first specification shows that a one unit change in the proportion of unrestricted funds leads to a $14.6 \%$ decrease in the return on charity expenditures. This shows that, when accounting for charity fixed effects, a shock to the funding structure in the direction of more unrestricted funds lowers the contemporaneous cost-effectiveness. This finding is confirmed by the results from specification (3), where we look at the cost-effectiveness of unrestricted as well as fully restricted charities relative to those with mixed funding structures. We see that those which are 
unrestricted show a slight negative significant effect on cost-effectiveness. Remarkably, those which are fully restricted show an even larger negative significant effect.

Next we study potential dynamic effects. It is plausible that a shock to the funding structure does not only affect the current effectiveness, but also effectiveness in the next period. Due to the short nature of our panel (three time periods), we can only study the one year lagged time effects. We show the results in Specifications (2) and (4) in Table 2.4. The negative contemporaneous effect of an increase in the proportion of unrestricted funds is associated with a positive lagged relationship. This shows that, while a positive shock to the proportion of unrestricted funds in the current period lowers effectiveness, it has a positive effect in the following year. Thus, the dynamic response to a shock in the funding structure is important in determining how trustees and charities respond to incentives.

\subsection{Discussion and conclusion}

This paper studies the effect of charity characteristics on charity performance. By first studying time invariant characteristics and the cross section of cost-effectiveness, we find that charities that are either unrestricted or fully restricted appear to perform significantly better than charities with mixed funding structures. This implies that when the underlying incentives are either completely defined or completely undefined the trustees do a better job. It hints at the possibility that a mixed funding structure harms a charity's effectiveness presumably because trustees have to balance their own interest with those from the outside. Further, we show that having trustees on the board who are connected to other charities has a negative impact. This suggests that having a connected trustee significantly changes the way charities behave in terms of charitable activities. Unfortunately, it is beyond the scope of this study to investigate potential causal relationships arising from the network structure.

Finally, to test for incentive effects and the presence of asymmetric information, we examine the relationship between changes in cost-effectiveness and changes to the funding structure. The results suggest that the contemporaneous relationship is negative and thus indicates the presence of moral hazard, since by less donor control over how funds are spent trustees are able to exert lower effort. The lagged relationship is positive and signif- 


\begin{tabular}{|c|c|c|c|c|}
\hline & $\begin{array}{c}(1) \\
\log R\end{array}$ & $\begin{array}{c}(2) \\
\log R\end{array}$ & $\begin{array}{c}(3) \\
\log R\end{array}$ & $\begin{array}{c}(4) \\
\log R\end{array}$ \\
\hline $\mathrm{F}$ & $\begin{array}{c}-0.146^{* *} \\
(0.059)\end{array}$ & & & \\
\hline $\mathrm{F}(-1)$ & & $\begin{array}{l}0.084^{*} \\
(0.050)\end{array}$ & & \\
\hline Unrestricted & & & $\begin{array}{c}-0.061^{* *} \\
(0.027)\end{array}$ & \\
\hline Fully restricted & & & $\begin{array}{c}-0.164^{* *} \\
(0.068)\end{array}$ & \\
\hline Unrestricted $(-1)$ & & & & $\begin{array}{c}0.031 \\
(0.022)\end{array}$ \\
\hline Fully restricted $(-1)$ & & & & $\begin{array}{c}0.026 \\
(0.060)\end{array}$ \\
\hline log Total assets (GBP million) & $\begin{array}{c}0.017 \\
(0.015)\end{array}$ & & $\begin{array}{c}0.003 \\
(0.005)\end{array}$ & \\
\hline $\log$ Total assets $\times \mathrm{F}$ & $\begin{array}{l}-0.020 \\
(0.016)\end{array}$ & & & \\
\hline $\log$ Total assets (GBP million) $(-1)$ & & $\begin{array}{l}-0.031^{*} \\
(0.016)\end{array}$ & & $\begin{array}{l}-0.008 \\
(0.006)\end{array}$ \\
\hline $\log$ Total assets $(-1) \times F(-1)$ & & $\begin{array}{l}0.030^{*} \\
(0.017)\end{array}$ & & \\
\hline Constant & $\begin{array}{c}0.161^{* * *} \\
(0.043)\end{array}$ & $\begin{array}{c}-0.120^{* * *} \\
(0.037)\end{array}$ & $\begin{array}{c}0.078^{* * *} \\
(0.010)\end{array}$ & $\begin{array}{c}-0.069^{* * *} \\
(0.008)\end{array}$ \\
\hline Observations & 18,006 & 9,223 & 18,006 & 9,223 \\
\hline R-squared & 0.002 & 0.002 & 0.002 & 0.001 \\
\hline
\end{tabular}

Table 2.4: Fixed effects regressions of the proportion of unrestricted funds, $F$, on costeffectiveness, $R$, with clustered standard errors. The results show that contemporaneously, cost-effectiveness is significantly hurt by an increase in unrestricted funds. The one year lagged relationship is reversed and significantly positive.

icant, suggesting that a lagged increase in the proportion of unrestricted funds increases cost-effectiveness. This would be consistent with a scenario where current investments pay off in later time periods. It thus suggests that studying one period changes may only provide partial insight into the mechanism at work.

Overall, our results lend partial support to the existence of asymmetric information. Regrettably, due to the short time dimension of the data, it is not possible to study longer term effects of changes in the funding structure of charities and its effect on cost-effectiveness. Studying the time dynamics over a longer horizon may yield additional insights into this behavior. 


\subsection{Appendix: Classes and categories}

\begin{tabular}{crl}
\hline Class & Type & Description \\
\hline 1 & 1 & General Charitable Purposes \\
1 & 2 & Education/Training \\
1 & 3 & The advancement of health or saving of lives \\
1 & 4 & Disability \\
1 & 5 & The Prevention or relief of Poverty \\
1 & 6 & Overseas aid/Famine relief \\
1 & 7 & Accommodation/Housing \\
1 & 8 & Religious activities \\
1 & 9 & Arts/culture/heritage/science \\
1 & 10 & Sport/recreation \\
1 & 11 & Animals \\
1 & 12 & Environment/Conservation/Heritage \\
1 & 13 & Economic/Community development/Employment \\
1 & 14 & Other charitable purposes \\
\hline 2 & 1 & Children/Young people \\
2 & 2 & Elderly/Old People \\
2 & 3 & People with disabilities \\
2 & 4 & People of a particular ethnic or racial origin \\
2 & 5 & Other charities/Voluntary bodies \\
2 & 6 & Other defined groups \\
2 & 7 & General public/Mankind \\
\hline 3 & 1 & Makes grants to individuals \\
3 & 2 & Makes grants to organizations \\
3 & 3 & Provides other finance \\
3 & 4 & Provides human resources \\
3 & 5 & Provides buildings/facilities/open space \\
3 & 6 & Provides services \\
3 & 7 & Provides advocacy/advice/information \\
3 & 8 & Sponsors or undertakes research \\
3 & 9 & Acts as umbrella or resource body \\
3 & 10 & Other charitable activities \\
\hline & &
\end{tabular}

Table 2.5: Classes and categories 



\section{Chapter 3}

\section{Experience and learning in internet auctions}

\subsection{Introduction ${ }^{1}$}

In several market institutions, experience significantly influences behavior. List (2003) conducts a field study investigating the role of experience by comparing the magnitude of the endowment effect between dealers and non-dealers of sports collectibles. Not surprisingly, increased experience eliminates the endowment effect and brings behavior closer to predictions of rational behavior. List (2004) extends these findings and shows that while behavior of inexperienced individuals can be predicted well by prospect theory, experience makes individuals act more in line with neoclassical predictions. In a study of learning on equity markets, Seru et al. (2010) show that individual investors learn in two ways: either they improve their performance or they exit the market. Conducting auction experiments, Kirchkamp and Reiß (2011) find that bids converge toward the risk neutral equilibrium strategy within less than ten rounds, suggesting that there is no persistence in overbidding. Although present in the experimental literature, there is little evidence of experience affecting overbidding studying auction field data. For instance, Lee and Malmendier (2010) show that all bidders overbid re-

\footnotetext{
${ }^{1}$ This chapter is based on 'Myopic bidders in internet auctions', co-authored with Rachel Pownall. We would like to thank Jonathan Batten, Dakshina G. De Silva, Piet Eichholtz, Doug Emery, Victor Ginsburgh, Tim Hubbard, Dan Levin, Charles Noussair, Ronald Peeters, Philipp Reiß, Arno Riedl, as well as the audiences at Maastricht University, Texas Tech University, FMA Asia 2011 in Queenstown, EEA 2011 in Oslo, SEA 2011 in Washington DC, the Art Markets Symposium 2010 in Paris, and the Art Markets Workshop 2011 at Universite libre de Bruxelles for valuable comments and suggestions.
} 
gardless of their experience level in internet auctions.

Auction experience instead of affecting valuations has been shown to affect the timing of bids. Wilcox (2000) suggests that more experienced bidders submit their bids later within an auction, whereas Borle et al. (2006) show that more experienced bidders appear to bid either at the start or at the end of the auction. Novice bidders on the other hand are active throughout the entire auction. The differences in bidding behavior can partly be traced back to differences in bidding strategies. Novice bidders are more likely to bid incrementally, whereas the behavior of more experienced bidders is closer to the (weakly) dominant strategy in sealed bid auctions (Zeithammer and Adams, 2010). Analyzing the time series of 131 eBay bidders, Wang and $\mathrm{Hu}$ (2009) confirm that more experienced bidders submit their bids later within the auction.

If experience plays a significant role in shaping bidding behavior, it can have a large impact on the design and operation of auction markets. DellaVigna and Malmendier (2004) show that firms need to respond to consumers making biased decisions in order to maximize revenues. Similarly, Simonsohn and Ariely (2008) show that eBay bidders herd into auctions that have already attracted existing bids and thereby pay higher prices than if they entered auctions with fewer existing bids. Consequently, profit maximizing auctioneers should observe bidding behavior and take behavioral bidders into account when designing their market institutions. In auctions, it is sufficient that a small fraction of the bidders overbid to drive up prices and delay purchase of a good by a non-overbidding consumer (Malmendier and Szeidl, 2008). Understanding the extent of overbidding can also help a potential bidder to make an inference about the expected behavior of his possible opponents and thereby improve his expected payoff.

In this paper we explore the relationship between bidding behavior and experience using a unique field dataset of internet art auctions. We rely on repeated observations for each bidder and can thereby analyze how behavior is affected over time. Due to the particular design of the auction platform that we study we are able to both follow bidders and compare bids across auctions. We collect auction records from 8000 internet art auctions, including individual bids as well as the associated bidder identities. The sample covers all internet art auctions conducted at a Scandinavian specialist auction house over a period of more than one year. The objects that 
are auctioned are in the lower price range of the art market.

Our findings show that experience significantly affects bidding behavior. We find that bidders learn to avoid myopia and incorporate the possibility to participate in future auctions into their bids. Our findings relate to the evidence presented by Zeithammer (2006). The author shows that transaction prices are reduced when similar objects are auctioned sequentially close in time. Our evidence partially deviates from the findings of Lee and Malmendier (2010). It is likely that learning disappears within a few rounds making it difficult to detect on eBay where the number of new entrants in each auction is relatively small compared to the existing pool of bidders. Since we can follow bidders from their first bid, we are able to capture the initial learning. We show that the bid reduction, when comparing the first auction to 11 or more auctions, ranges from $10 \%$ to $20 \%$.

Our study contributes to several fields of research. First, it contributes to the growing literature on bidding behavior in internet auctions. Starting with Bajari and Hortaçsu (2003), internet auctions have received widespread attention, and several behavioral phenomena have been studied (see Bajari and Hortaçsu (2004) for a survey). Within this field, our contribution is that we study heterogeneous goods for which an expert estimated value is available. This enables us to follow the same bidder through a series of auctions. Previous studies have been concerned with objects that are homogeneous, in the sense that there exists a book value in the form of a list price, such as Intel Pentium processors (Bajari and Hortaçsu, 2003), collectible coins (Hauser and Wooders, 2006) and golf clubs (Livingston, 2005). In these settings, it is difficult to observe the same bidder twice. A notable exception is Goes et al. (2010) who study sequential auctions of homogeneous goods sold to retailers online. The authors show that willingness-to-pay is affected more from winning than from the experience gained through participating in more auctions.

Second, auctions for art are also interesting venues to study. Research on art auctions and markets have so far mainly focused on the risk and return relationship from the perspective of an investor, showing moderate returns (Mei and Moses, 2002) and that owners must gain utility by owning an artwork to compensate for these lower returns (Mandel, 2009). On the seller side, Beggs and Graddy (1997a) show that, throughout an art auction sale, objects were sold in order from high to low presale estimates. In addi- 
tion, prices decline relative to presale estimates throughout the auction. The authors show that this behavior is in line with a revenue maximizing auctioneer. The effort to understand art auctions has also revealed some interesting anomalies. Beggs and Graddy (2009) show that there is strong buyer anchoring effects present in art auctions. The authors control for observed as well as unobserved painting characteristics by using a repeated sales method. Goetzmann and Spiegel (1995) decompose returns from paintings into a temporal and private value component. The authors argue that, since the number of potential bidders declines immediately after a sale, a winning bidder overpays, especially for short holding periods. Mei and Moses (2005) show that presale estimates for high-priced paintings have a systematic upward bias, which is persistent over time and which results in lower subsequent returns. Within this area, our study contributes by being the first study to consider bid-level data for art auctions, as well as art sold on the internet.

Finally, our study contributes to behavioral industrial organization that has emerged as a response to profit-maximizing firms who serve boundedly rational consumers (DellaVigna, 2009). On eBay, Brown et al. (2010) show that sellers with low shipping charges increase expected revenues by disclosing these costs, while at the same time by keeping costs hidden a seller can increase his revenues by increasing the shipping costs. More specifically, our study contributes by studying the repeated behavior of bidders in internet auctions, enabling auctioneers to understand better the behavior of bidders and thereby to improve their market institutions. Given the vast amount of historical data available to auctioneers, it could lead to significant improvements in revenues.

The remainder of the paper is structured as follows. In section two, we discuss the related literature and set out the approach to capture the presence of learning effects, in section three we introduce the dataset. Section four presents the empirical method by which we study bidding behavior and presents the results. The final section discusses the results and concludes. 


\subsection{Background}

\subsubsection{Outside options in auctions}

In a second-price private value auction, when studied in isolation, the equilibrium strategy for a bidder is to bid his valuation (Krishna, 2002). However, when substitute goods are auctioned sequentially this is no longer necessarily the case. Under such circumstances, a bidder can benefit from the outside option of acquiring the item in a later auction. Jofre-Bonet and Pesendorfer (2003) study the inter-temporal dynamics of such options in highway procurement auctions. The authors find that capacity constraints of bidders significantly alter their subsequent bidding and result in price inefficiencies that result in increased prices paid by the auctioneer to the winning bidder. Similarly, Zeithammer (2006) studies the presence and magnitude of forward-looking bidders on eBay. Internet auctions provide an ideal setting to study forward-looking behavior of bidders, since information about future supply is readily available through the bidding website.

The significance of outside options has also been studied experimentally. Kirchkamp et al. (2009) set up an auction market by allowing bidders to buy an outside option before, during, or after the auction has ended, conditional upon the bidder not winning the auction. The authors show through a series of experiments that bidders seem incapable of adjusting their bids to reflect the value of the outside option in first price auctions, while bidders appear to almost fully shade their bids in accordance with the outside option in second-price auctions. The setup is similar to our field auctions. However, internet auctions are run sequentially which enables information from previous auctions to be used in future auctions. We therefore investigate the dynamics of the inter-temporal setting in order to understand the bidding process.

Jeitscko (1998) analyzes learning in a two-period first price auction and shows that the dynamic environment creates an option value for participating in the second auction whilst bidding in the first auction. Said (2010) sets up a dynamic second price auction market with randomly arriving buyers. ${ }^{2}$ The market is set-up as an infinite discrete-time model with at least two bidders in each time period with unit demand. Every time period has at most

\footnotetext{
${ }^{2}$ As argued by Song (2004) bidders on eBay may not arrive randomly due to entry being dependent on the current bid. Therefore, only a subset of all potential bidders submits a bid. The auctions we study in this paper also potentially suffer from this problem.
} 
one seller. The objects that are sold are imperfectly substitutable, which induces variation in their valuation. This is similar to our setting and we adopt this model when we look at auctions for art. Said (2010) shows that in equilibrium a bidder will bid his valuation less the option value of participating in future auctions. For bidder $i$ this translates into the bid being a function of the valuation, discounted by the option value:

$$
b_{i}=v_{i}-\delta W
$$

where $b_{i}$ is the submitted bid, $v_{i}$ is his valuation for the object, $\delta$ is the discount rate, and $W$ is the option value. See Said (2010) for a full derivation of the equilibrium bid and the difference equations characterizing $W$. It is important to note that $W$ is a constant and it is also common to all bidders. A bidder has to correctly estimate $W$ in order to sufficiently shade his bid to account for future auctions. A rational bidder will do precisely that, but if a bidder is myopic or, in other words, if he ignores the value of the option, he will outbid the rational buyer since $W$ is always non-negative. Our definition of myopia follows that of Jeitscko (1998), who assumes that a bidder who disregards future auctions in a sequential setting is myopic.

Taken together with evidence that experience makes individuals behave more rationally (List, 2003,0), we hypothesize that inexperienced bidders will fail to account for the full option value. Only as bidders gain more experience will they learn to avoid myopic bidding strategies. Their bidding behavior will thereby converge to equilibrium. There is experimental evidence for this type of convergence happening in auction settings. Kirchkamp and Reiß (2011) conduct a series of first-price auction experiments to study out-of-equilibrium behavior and show that bids converge relatively quickly to the risk neutral Bayesian Nash Equilibrium of the game. Even though their experiment lasts for 12 rounds, most of the bid adjustment occurs in the first six sessions.

\subsubsection{Internet auctions}

There are several potential problems when studying auction field data. On the one hand, the objects are heterogeneous and on the other hand bidders may bid incrementally. The possibility to bid incrementally invalidates many of the predictions of standard auction theory. We approach these two problems separately. First, when studying heterogeneous objects, we cannot 
directly compare bids across auctions for different paintings. To compare bids across auctions, we would have to observe each bidder's valuation of the object he bids for. Since this is not possible with field data, we take the standard approach to homogenize the bids instead. This method was initially proposed by Haile et al. (2003) and allows us to effectively control for the heterogeneity present.

Second, it is possible to bid incrementally which means that we do not observe all bidders that potentially would enter the auction. Using a common value assumption, Bajari and Hortaçsu (2003) show that it is an equilibrium for all bidders to bid in the last minute. This makes it possible to analyze the auction, not as an ascending auction with incremental bidding but instead as a second price sealed bid auction with a stochastic number of bidders. Following these lines, Bajari and Hortaçsu (2003) derive equilibrium bids when the number of bidders is stochastic. Similarly, Ockenfels and Roth (2006) model an internet auction as a two-stage game where a second stage bid is lost during transmission with a positive probability. In such a game, bidding in the second stage sealed bid auction is a best response to incremental bidding.

Hossain (2008) approaches the problem from a different perspective. The author introduces one uninformed and one informed bidder in a dynamic private value auction. The uninformed bidder is not sure about his value for the object, and only knows whether or not he values it higher or lower than the current price. In this sense, Hossain (2008) shows that the unique equilibrium behavior by the informed bidder is to bid at the very end of the auction as a response to the incremental bidding by the uninformed bidder who learns from bidding.

\subsection{Empirical study}

\subsubsection{The auctions and the bidders}

We collect auction records from Auktionskompaniet.com, an internet auction house specialized on antiques and a subsidiary of Bukowskis Auktioner $\mathrm{AB}$ in Sweden. The auctions are designed in such a way that there are no reputational effects and quality cannot be misrepresented by the seller on purpose. This has the advantage that, when studying learning effects, the ex post risk, or the risk that a buyer faces after the good has been purchased, 
is very low. The objects are in the low end of the price distribution of the art market and mainly consist of Scandinavian artworks. The paintings sell with a mean price of 1608 SEK. $^{3}$ Our dataset contains 8000 paintings auctioned between April 7, 2008 and November 16, 2009.

The mechanics of the selling procedure are as follows. The seller sends his object to the auction house, which produces high resolution photos and detailed descriptions of physical characteristics, including any damages. In addition to that, the auction house values the object using an expert. Details are then published on the website and the auction can start. It is an ascending auction, comparable to eBay, where all bidders can observe past bids, and whether or not the bids are above the secret reserve price. We only observe actual bids, and do not have the possibility to observe the underlying valuations of bidders who refrain from bidding.

During the auction, the auction house keeps the object in one of their warehouses and, when the auction ends, the buyer can pick the object up in the appropriate warehouse or have the object delivered to his door. Unlike eBay, there is no possibility for a seller to enable a buy-it-now option. A seller might choose to set a secret reserve price or not. The secret reserve can be set to no less than 200 SEK and not more than $80 \%$ of the estimate. Sellers cannot not set a own minimum bid levels, the minimum bid is instead dictated by the auction site. We show the minimum increments in Table 3.1. Shipping costs vary with the size and location of the object, but it can always be picked up by the buyer at no charge directly from the warehouse where it is stored.

\begin{tabular}{l|lll}
\hline Current bid: & $200-999$ & $1.000-1.999$ & $2.000-9.999$ \\
Minimum increment: & 50 & 100 & 200 \\
& & & \\
Current bid: & $10.000-19.999$ & $20.000-39.999$ & $40.000-$ \\
Minimum increment: & 500 & 1.000 & 2.000 \\
\hline
\end{tabular}

Table 3.1: Minimum bid at current bid levels. All prices are reported in SEK.

Our data include individual bids, expert estimates of their values, as well as several other variables such as the length of the auction, timing of bids and bidder identities. The bidder identities allow us to uniquely track individual bidders across auctions. An overview of the descriptive statistics can be found in Table 3.2.

\footnotetext{
${ }^{3}$ At the time of the study $\$ 1 \approx 7.71$ SEK on June 30, 2009.
} 
The aim of our study is to determine how participants bid conditional on their experience. In our sample we have 5019 unique bidders, who participate on average in 5.95 auctions. A deeper look at the number of auctions that the different bidders participate in reveals that there is a heterogeneous bidder population. The maximum number of auctions a single bidder participated in is 741, while at the same time 2115 bidders only participate in a single auction. The different bidders and the number of auctions participated in are shown in Figure 3.1. The average bidder wins 33\% of the auctions he participates in.

We next look at the proportion of late bids. In our dataset, the proportion of bids arriving within the last ten minutes of the auction correspond to around $30 \%$ compared to $5 \%$ to $20 \%$ in Ockenfels and Roth (2006). The arrival of final bids is depicted in Figure 3.2. While a few bidders might refrain from bidding due to bids posted during the incremental bidding phase, our evidence suggests that a significant portion of bids are posted at the very end of the auction. ${ }^{4}$ This supports the argument of modeling the auction as a two-stage game where bidding occurs as in a second price sealed bid auction at the end.

The advantage of our study is that we are able to record the bidders from the first time they bid for an artwork on the auction site of this auction house. Potentially, bidders could have prior experience on the same platform from two sources. First, they may have participated in auctions for antiques on the same website. We do not record these auctions. Second, there was an earlier implementation of the auction site where bidders could have participated. We only record auctions from the present platform. Prior

\footnotetext{
${ }^{4}$ No bids arrive within the last minute of the auction, whereas approximately $10 \%$ of the final bids arrive in the second last minute. This probably is a result of how bids and transaction times are recorded on this particular platform.
}

\begin{tabular}{llllll}
\hline Variable & Mean & Median & Minimum & Maximum & S.d. \\
\hline Price & 1608 & 850 & 0 & 94000 & 2681 \\
Bid & 1366 & 702 & 200 & 94000 & 2254 \\
Estimate & 1568 & 1000 & 200 & 35000 & 1709 \\
Length (days) & 41.52 & 27.00 & 7 & 387 & 37.88 \\
\# Bids & 6.68 & 5 & 0 & 44 & 5.34 \\
\# Bidders & 3.72 & 3 & 0 & 13 & 2.10 \\
\% Sold & 97.2 & - & - & - & - \\
\% Damaged & 66.3 & - & - & - & - \\
\hline
\end{tabular}

Table 3.2: Descriptive statistics of all observed auctions. Prices and estimates are in SEK. 


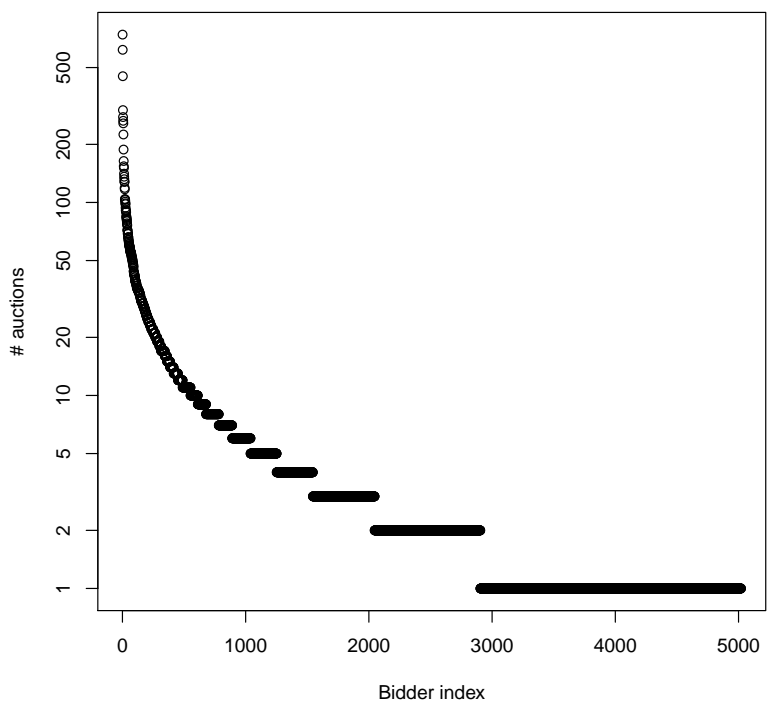

Figure 3.1: Number of auctions participated in, sorted from high to low. The figure shows that the vast majority of bidders only participate in one auction and that only a few participate in more than 100 auctions.

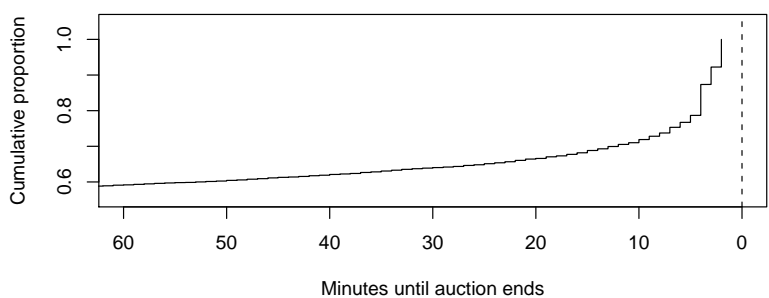

Figure 3.2: Arrival of bids in the last hour of the average auction. The horizontal axis shows, from left to right, the minutes until the auction ends. The vertical axis plots the cumulative proportion of bids received. At the end of the auction this is always 1.

experience in auctions, whether online or offline, would bias results downward and thus make us underestimate any behavioral changes arising from experience. 


\subsubsection{Learning through experience}

In line with Asker (2010), we assume that bids are multiplicatively separable into the observed characteristics of the object and the unobserved private value. The reason for adopting a multiplicative separable approach is that the fit is better than in the case of an additive model. ${ }^{5}$ Following Asker (2010), we decompose a bid $b_{i t}$, into:

$$
b_{i t}=\Gamma\left(z_{t}\right) \times \tilde{b}_{i t}
$$

where $z_{t}$ represents a matrix of covariates that captures the heterogeneity of the objects. We specify $z_{t}$ to include a constant and the expert estimated value of each object. We take logs and estimate the homogenized bid $\log \left(\tilde{b}_{i t}\right)$ using a single stage linear regression following Haile et al. (2003) and applied in Asker (2010). The expert estimate is made prior to the auction, it should thus capture all characteristics of the object so that little or no characteristics remain unobserved and the number of actual bidders serves as a proxy for characteristics that are unobserved to the expert but not to the bidders. We report the regression coefficients and a histogram of the distribution of the normalized bids in the Appendix.

We continue by classifying a proxy for experience in auctions. Within the private value setting, bids should be uncorrelated with experience as long as bidders accurately estimate and know their own valuation. However, if a bidder faces uncertainty about his own valuation, the bidder can learn through bidding relative to his previous bids or relative to the other bidders' bids. This occurs by either by winning the object, and then revising the valuation ex post, or by observing other bidders throughout the auction and thereby reducing uncertainty. In the first case, learning will occur when the object is won, and, in the latter, learning will occur both when the object is won and when it is not.

We sort the dataset of all bids on the bidder identifier and on the date and time that a particular auction ended. We then define three proxies for experience. First, we use the cumulative number of previous auctions participated in, starting at one for the first auction. We implement two alternatives of this proxy by first using the previous number of wins and second the previous number of auctions conditional upon only losing. We

\footnotetext{
${ }^{5}$ We provide a comparison of the distribution of the estimated private value using both the multiplicative and additive approach in the appendix.
} 
drop all auctions with less than two bidders. Following this procedure, each bid has a proxy specific experience level associated with it. Our proxies are closely related to the cumulative trades proxy used by Seru et al. (2010), who find that cumulative trades is a better proxy for experience than time.

(a) All

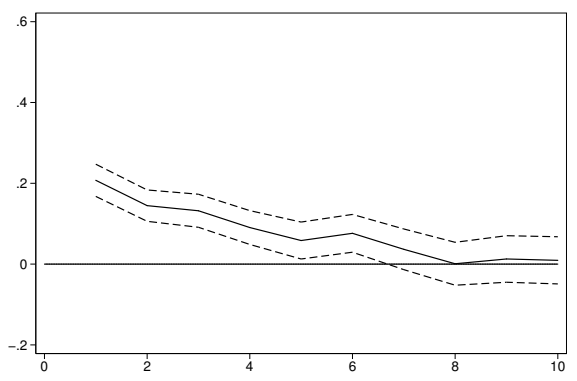

(b) Losses only

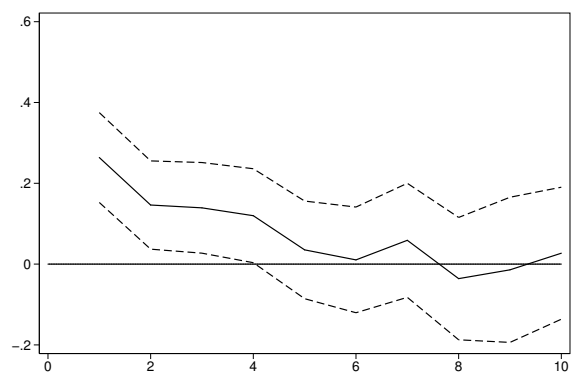

(c) Wins only

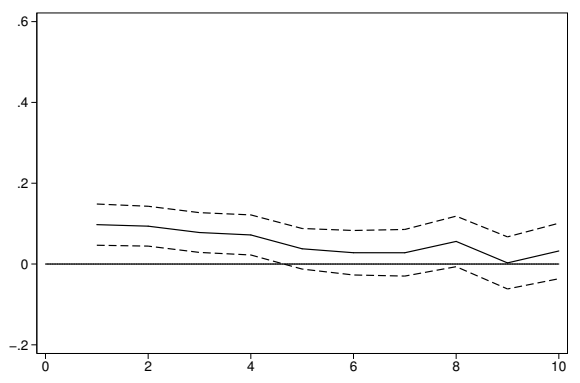

Figure 3.3: The magnitude of learning relative to auction 11 and higher for the three experience proxies. The x-axis shows the auction number and the $y$-axis the coefficient magnitude. The solid lines represent the coefficients from the fixed effects regressions in Table 3.3. The dashed lines are the $95 \%$ confidence intervals. All three plots reveal significant learning effects.

\subsubsection{The amount bid}

We continue by estimating the changes in bids for the first ten experience levels. Thus our omitted group in the regression is experience level 11 and above. Hence, all results are relative to participating, winning or losing in auction 11 or more. We implement two specifications, OLS and bidder fixed effects. Specifically, we estimate the parameter vector $\beta$ for the following two models, 


$$
\begin{aligned}
& \log \left(\tilde{b}_{i}\right)=\mathbf{x}_{i}^{\prime} \boldsymbol{\beta}+u_{i}, \\
& \log \left(\tilde{b}_{i t}\right)=\mathbf{x}^{\prime}{ }_{i t} \boldsymbol{\beta}+c_{i}+u_{i t},
\end{aligned}
$$

where $\mathbf{x}_{i}$ and $\mathbf{x}_{i t}$ are sets of dummy variables used to assign an experience level to each homogenized bid and a set of auction specific covariates. The auction specific covariates include the length of the auction and the squared length to control for differences in visibility, the number of actual bidders to control for potential differences in competition, as well as whether or not the item has any sort of recorded damage.

Equation 3.2 is a standard OLS specification with residual $u_{i}$. In Equation 3.3, we additionally adjust for bidder fixed effects. The reason for following this approach is that our results may be affected by unobserved bidder heterogeneity. If each bidder is of a different type where some types enjoy bidding more than others, then participation could be correlated with the type of bidder. This correlation might affect our results and thus overstate the magnitude of learning that arises from experience. To alleviate such concerns we implement a fixed effects model.

In Figure 3.3, we plot the experience coefficients from our regressions. All three proxies show that the bids are significantly higher in the first auction relative to the omitted group. The OLS regressions show strong learning effects with bids revised downwards by $26 \%$ to $70 \%$ compared to auction 11 and higher. The strongest learning effects arise from losing at an auction and the weakest effects after winning. Controlling for bidder fixed effects, we see that the coefficients drop. The learning effect is reduced to $10 \%$ to $20 \%$. The order of the coefficient magnitudes is the same, and we see again, consistent with the previous specification, that previous losses produce the strongest learning effects. The coefficients and the significance levels are presented in Table 3.3.

To verify that our results are not driven by noise, we aggregate the experience levels into four groups of five previous auctions each up to and including 20 previous auctions. These results are presented in Table 3.4. The results confirm the earlier findings from the regressions on the individual experience level with highly significant coefficients when aggregating auction one to five for all three proxies. 


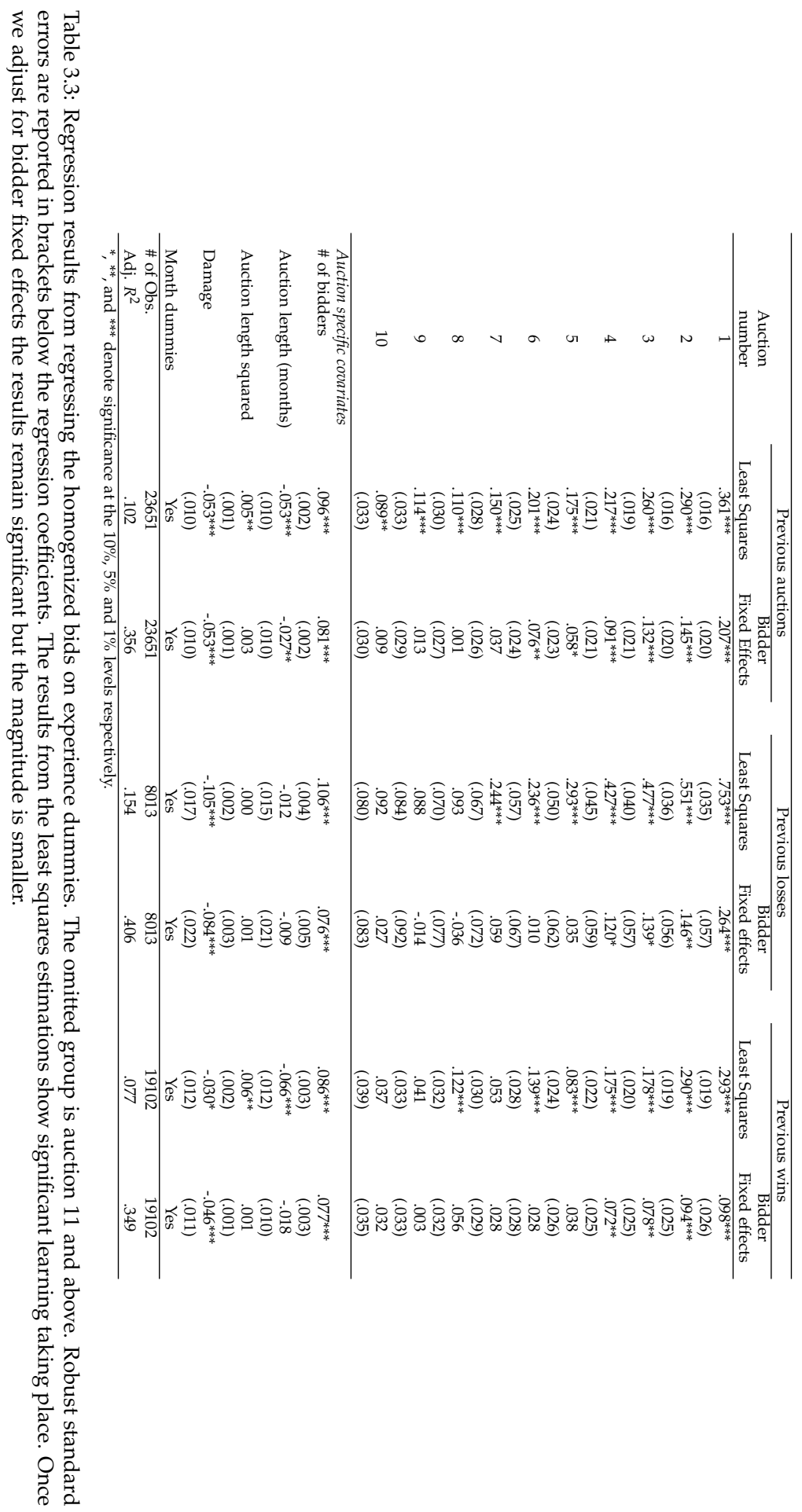




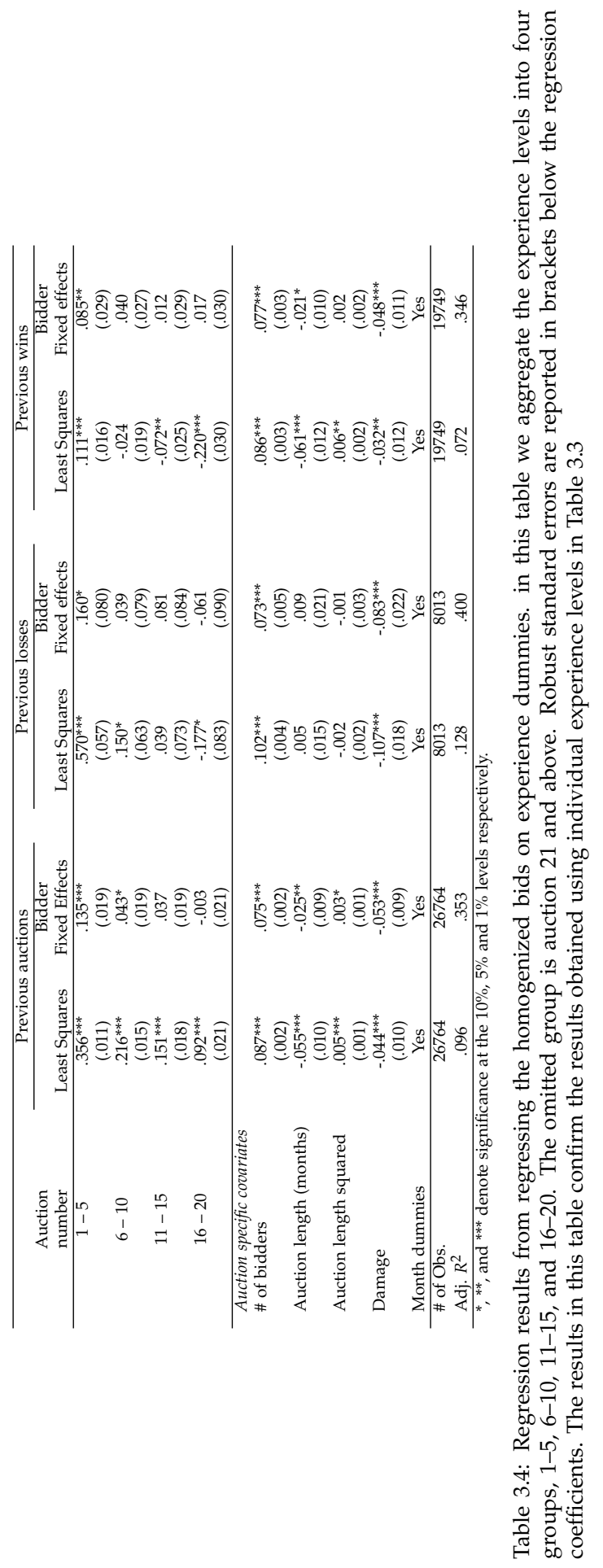




\subsubsection{The probability of winning}

Due to the design of second-price auctions, the distribution of observed bids is censored at the second highest valuation. It is common practice to recover the distribution of valuations by assuming that online auctions are strategically equivalent to sealed-bid auctions. Through a series of nonparametric tests, Zeithammer and Adams (2010) show that this abstraction does not hold for eBay. Consequently, in this section, we study how the probability of winning is linked to experience as an alternative way to extract information on learning.

The probability of winning an auction is directly linked to the amount bid. Ceteris paribus, a higher bid by the bidder results in a higher probability of winning the auction. Thus, if experienced bidders learn to account for future options they should also be less likely to win an auction at a later date. To check for this, we estimate a logistic regression similar to our linear regression models in Section 3.3.3, only this time we define the dependent variable simply as 'winning the auction'.

The results are presented in Table 3.5, which shows the estimated odds ratios for the coefficients of the pooled logistic regression as well as the fixed effects panel logistic regression. We estimate both a pooled and a bidder fixed effects specification which confirm our previous results on the presence of learning. Similarly, we observe a consistent pattern of decreasing coefficients as experience increases. Relative to a bidder in auction 11 and above, a bidder in his first auction is almost 1.8 times more likely to win, as it can be seen in the specification with bidder fixed effects. This means that, relative to other bidders, more experienced bidders bid less. Hence, the action of bidders to reduce their bids in subsequent auctions, that we observe in Section 3.3.3, arises from learning and is directly connected to the experience of the bidder.

\subsubsection{Alternative explanations}

Apart from learning, our results could be driven by other factors. First, the timing and the order in which bids are submitted within an auction matters. Following the argument by Roth and Ockenfels (2002), late bidding is an equilibrium strategy to avoid bidding wars. One would then expect experienced bidders to bid late, and thus bid higher on average with more experience. However, these bids would at the same time be censored and 


\begin{tabular}{|c|c|c|}
\hline $\begin{array}{l}\text { Auction } \\
\text { number }\end{array}$ & Pooled & $\begin{array}{c}\text { Bidder } \\
\text { Fixed Effects }\end{array}$ \\
\hline 1 & $\begin{array}{c}2.200^{* * *} \\
(.092)\end{array}$ & $\begin{array}{c}1.796^{* * *} \\
(.158)\end{array}$ \\
\hline 2 & $\begin{array}{c}1.976^{* * *} \\
(.085)\end{array}$ & $\begin{array}{c}1.613^{* * *} \\
(.165)\end{array}$ \\
\hline 3 & $\begin{array}{c}1.768^{* * *} \\
(.112)\end{array}$ & $\begin{array}{c}1.503^{* * *} \\
(.138)\end{array}$ \\
\hline 4 & $\begin{array}{c}1.677^{* * *} \\
(.100)\end{array}$ & $\begin{array}{c}1.415^{* * *} \\
(.128)\end{array}$ \\
\hline 5 & $\begin{array}{c}1.496^{* * *} \\
(.101)\end{array}$ & $\begin{array}{c}1.251^{* *} \\
(.103)\end{array}$ \\
\hline 6 & $\begin{array}{c}1.555^{* * *} \\
(.125)\end{array}$ & $\begin{array}{c}1.293^{* *} \\
(.111)\end{array}$ \\
\hline 7 & $\begin{array}{c}1.353^{* * *} \\
(.117)\end{array}$ & $\begin{array}{l}1.117 \\
(.132)\end{array}$ \\
\hline 8 & $\begin{array}{c}1.538^{* * *} \\
(.141)\end{array}$ & $\begin{array}{l}1.284^{*} \\
(.128)\end{array}$ \\
\hline 9 & $\begin{array}{c}1.367^{* *} \\
(.130)\end{array}$ & $\begin{array}{l}1.115 \\
(.130)\end{array}$ \\
\hline 10 & $\begin{array}{c}1.367^{* *} \\
(.145)\end{array}$ & $\begin{array}{l}1.173 \\
(.157)\end{array}$ \\
\hline Auction specific covariates & & \\
\hline \# of bidders & $\begin{array}{l}.744^{* * *} \\
(.007)\end{array}$ & $\begin{array}{l}.689^{* * *} \\
(.009)\end{array}$ \\
\hline Auction length (months) & $\begin{array}{l}.914^{* *} \\
(.027)\end{array}$ & $\begin{array}{l}.915 \\
(.043)\end{array}$ \\
\hline Auction length squared & $\begin{array}{l}1.010^{*} \\
(.004)\end{array}$ & $\begin{array}{l}1.011 \\
(.006)\end{array}$ \\
\hline Damage & $\begin{array}{c}.987 \\
(.034)\end{array}$ & $\begin{array}{l}1.008 \\
(.042)\end{array}$ \\
\hline Month dummies & Yes & Yes \\
\hline \# of Obs. & 23651 & 19929 \\
\hline Log likelihood & -12412.501 & -7303.905 \\
\hline
\end{tabular}

Table 3.5: Logit results from regressing winning on experience dummies. The omitted group is auction 11 and above. Bootstrapped standard errors are reported in brackets below the regression coefficients. This table shows the odds ratios of winning an auction relative to the omitted group. The results confirm our findings on the amount bid, presented in Tables 3.3 and 3.4. Overall, a bidder is almost twice as likely to win his first auction compared to his eleventh auction.

consequently recorded at a below valuation value. Our results point in the opposite direction: Experienced bidders are outbid by less experienced bidders, meaning that experienced bidders are not concerned about avoiding bidding wars. The pairwise correlation between experience and minutes remaining until the end of the auction is 0.18 ( $p$-value 0.000 ). Thus, more experienced bidders do bid earlier and we do not find empirical evidence in the art auctions that bidders are concerned with a possible bidding war.

Second, the time variation in bids could drive our results. Bids, and therefore also prices, vary over time, since at some points in time there may be more bidders active competing for the objects. This would not only drive up bids, but may also affect the number of new bidders who would enter the website. To identify possible time effects, we perform an Augmented Dickey-Fuller test on the average homogenized bid submitted each day. The test rejects the null hypothesis of a unit root, and thus time effects do not 
drive our results. ${ }^{6}$ A plot of the data series is available in Figure 3.4.

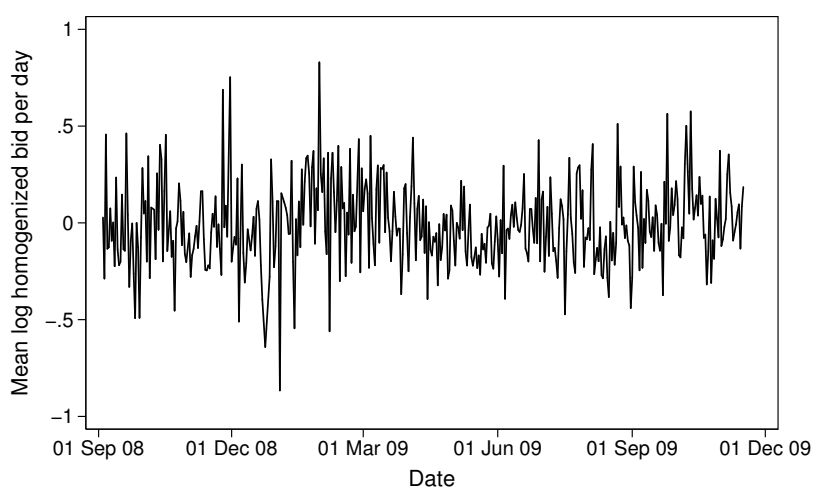

Figure 3.4: Average daily homogenized bid over time. The sample mean is -0.0076 . The series shows no persistence.

\subsection{Discussion and conclusion}

Using a unique dataset with repeated observations of the same bidder we are able to capture experience through transactions as well as through participation. A major advantage of our dataset is that the auction environment we study does not suffer from reliability issues and thus our results are not driven by sellers who behave dishonestly. Our results indicate that bids submitted by individual bidders in their first auction are $10 \%$ to $20 \%$ higher than those in auctions 11 and above. This shows strong supportive evidence for the fact that bidders lower their bids over time.

Our findings are consistent with the convergence of bids to the risk neutral equilibrium that is found in the experimental literature (see for instance Kirchkamp and Reiß, 2011). By allowing bidders to be myopic, i.e. to ignore the option value of participating in future auctions, they will appear to overbid. However, bidders learn to value the option over time. Even though we do not observe the true value of the objects being traded, it appears that the decrease in bids disappears within six to seven rounds. Furthermore, experienced bidders submit their final bids within an auction much earlier

${ }^{6}$ We perform the Augmented Dickey-Fuller test on 1, 5, and 10 lags with a constant as the deterministic component. In each case we reject the null hypothesis of a unit-root at the $5 \%$-level. The full results can be obtained from the authors upon request. 
than inexperienced bidders. We can infer from this evidence that these bidders are less concerned with entering a bidding war, consistent with bidders avoiding myopia.

Our results are different from the findings of Lee and Malmendier (2010) who do not find effects of experience by analyzing feedback scores from eBay. Feedback scores are updated only when a transaction occurs and are similar to our 'previous wins' proxy. This proxy shows the least amount of 'overbidding' out of the three proxies. Also, our evidence indicates that most learning disappears within five to seven auctions. Since the number of new entrants who bid on eBay are few compared to the pool of active/potential bidders, it might also be that the sample does not pick up enough inexperienced bidders to show that there is learning within the first few rounds. ${ }^{7}$

We examine the behavior of bidders as they gain experience with the trading institution at hand. While bidders in an auction experiment are mostly bidding against other bidders, who are equally unfamiliar with the current trading institution, an inexperienced bidder in the field gains experience with an institution while bidding against a distribution of bidders, some of whom are experienced, while others are new to the platform. As long as there is a single myopic bidder in the market, this might delay the purchase of items by rational bidders and therefore have a significant impact on the market as a whole.

The implications for auction platform operators are clear. A steady inflow of inexperienced bidders maintains persistence in overbidding and keeps prices high. Our evidence shows that the magnitude of the bid reduction is surprisingly large and there are significant revenue opportunities present for auctioneers who attract inexperienced bidders. The findings hold for all three proxies used to capture experience. For bidders, our results indicate that they on average overbid as much as $20 \%$ in their first auction relative to auction 11 and above. Thus, obtaining experience in auctions where prices are low will help alleviate a bidder's concerns for overbidding when bidding for higher priced items.

\footnotetext{
${ }^{7}$ Using eBay feedback scores from the Lee and Malmendier (2010) there does not appear to be a visible pattern linking feedback scores to the amount bid. We can provide figures upon request.
} 


\subsection{Appendix}

To homogenize the bids we can either assume that the bids are additively or multiplicatively separable into the observed characteristics of the object and the unobserved private value. We estimate both models, and show the regression coefficients in Table 3.6. The first column shows the additive model and the second the multiplicative model. In Figure 3.5 we plot the Q-Q plot of the homogenized bids using an additive and multiplicative approach. The plots reveal that the variance increases with the estimate and thus the log transformed model provides a better fit to the data.

\begin{tabular}{lcc}
\hline & Bid & $\log ($ bid $)$ \\
\hline Estimate & $.562^{* * *}$ & \\
& $(.006)$ & \\
Log(estimate) & & $.709^{* * *}$ \\
& & $(.007)$ \\
\hline \# of Obs. & 28826 & 28826 \\
Adj. $R^{2}$ & .242 & .270 \\
\hline
\end{tabular}

Table 3.6: OLS regression to calculate the homogenized bids. ${ }^{* * * * * *}$ represent significance at the $10 \%, 5 \%$ and $1 \%$ respectively. Standard errors are in brackets below the coefficients.

(a) Additive

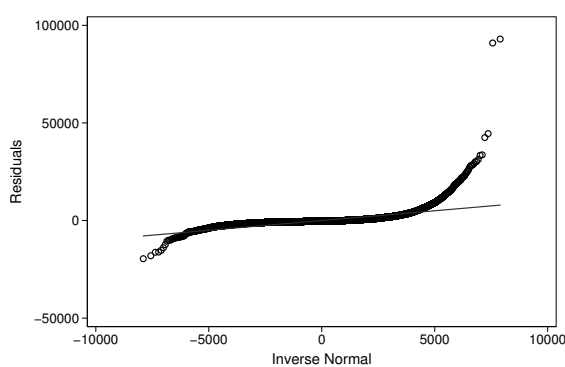

(b) Multiplicative

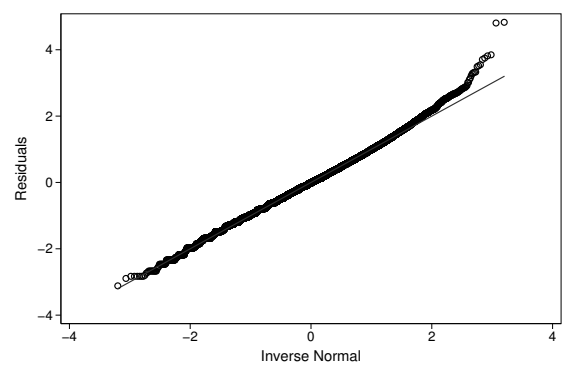

Figure 3.5: Q-Q plot of the homogenized bids of both models. 


\section{Chapter 4}

\section{Private and common values in art auctions}

\subsection{Introduction ${ }^{1}$}

There has been an increasing interest in understanding the role of emotions in economic decision making. Experimental evidence has shown that mood affects economic decision making. For instance, Kirchsteiger et al. (2006) find that good mood implies greater generosity in a gift-exchange game and Reuben and van Winden (2008) show that negative emotions help to explain negative reciprocity.

While there is plenty of experimental evidence from economics and psychology on the effect of mood on decision making, it has yet to be fully understood how the effect of mood carries over to economic behavior in the field. In this paper, we investigate the effect of mood in English auctions. In order to identify changes to mood we use the variation in the hours of daily sunshine as a proxy. Our approach enables us to compare our findings with those of Capra et al. (2010) which contributes to a better understanding of the effect of mood in auctions. We find that on the sunniest days, the prices obtained at auctions are higher for low priced paintings as compared to

\footnotetext{
${ }^{1}$ This chapter is based on 'Does the sun 'shine' on art prices?', published as De Silva et al. (2012). We would like to thank Victor Ginsburgh, Kathryn Graddy, Luc Renneboog, Robert Seamans, Sean $\mathrm{Wu}$, and Roberto Zanola, two anonymous referees, as well as the audiences at Texas Tech University, FMA 2011 in Denver, SEA/ACEI 2011 in Washington DC, IIOC 2011 in Boston, and the Art Markets Symposium 2010 in Paris for valuable comments and suggestions. We would also like to thank the UK Meteorological Office for supplying detailed weather data and we are grateful for the funding provided by the Maastricht University METEOR Research School.
} 
normal weather days during the winter and summer only. We control for seasonality, painting specific characteristics, and the auction house.

We collect data on art auction from both Sotheby's and Christie's over the period 1990-2007. London provides an ideal setting for studying the influence of weather on bidding behavior. First, in London the variation of sunshine is very high. The probability of rainfall is around $50 \%$, providing us with a setting in which we can study the effect of relatively sunny days. Second, London is one of the leading markets for art auctions, providing us with both high quality artworks as well as consistently high auction room attendance rates. This implies that both supply and demand should remain stable over time.

The contribution of our paper to the current literature is threefold. First, our results provide suggestive evidence for emotional influences on market prices beyond the stock market. This contributes to the literature on stock returns and weather induced behavior (see Hirshleifer and Shumway, 2003; Saunders, 1993). Second, the results highlight the importance of location specific factors on willingness-to-pay for objects with a relative high private value component. Finally, we study the influence of emotions in auctions using field data, giving empirical support to some of the experimental findings. Most notably, our findings support Capra et al. (2010).

There are several known price anomalies in art auctions. Beggs and Graddy (1997b) show that valuations are ordered from high to low throughout an auction, which coincides with the optimal strategy for selling heterogeneous items for the auctioneer. Mei and Moses (2005) show that price estimates are biased with respect to long-term performance. More recently, Beggs and Graddy (2009) show the effect from anchoring on art prices. We also contribute to this stream of literature by showing that there is a significant effect from mood present in the art market as captured by good weather days.

Our paper is organized as follows. In section two we discuss the private and common value components and how they relate to auction prices. We also describe the relationship and prior evidence on the weather and emotions in markets. We describe the data in section three and our results in section four. Finally, we discuss our findings and conclude the paper. 


\subsection{The value of art}

The value of art is determined by on the one hand, its future resale value and on the other hand, the emotional utility derived from owning the object. For art traded at an auction both components play important roles. Interestingly, the two components have very different characteristics from an auction theory point of view. The investment value will at any point in time for a fixed horizon be identical to all bidders, even though they have different information about it. This resembles a common value good, where every bidder only receives a noisy signal of the true value of the good. The emotional utility on the other hand, is strictly personal. The value someone derives from viewing a painting is independent from that of all other bidders. Thus, the emotional value represents a private value good. Goeree and Offerman (2003) show that when private and common value signals are drawn from log-concave distributions the value of the item is an additive combination of these two components. ${ }^{2}$ Thus, importantly every transaction price therefore has to be a combination of the private and common value components.

If the private value component makes up a relatively large part of the total value attached to a painting, we expect that variation in mood will affect auction prices. Paintings where this is the case carry a relatively lower common value component. This means that the resale value is less important. On the other hand, if the common value component is relatively more important, then the variation in the private value component will have a very low impact on transaction prices and thus carry little significance in explaining prices. We expect that low value paintings carry a large private value component and a low common value component, which reverses as we move up the distribution of prices.

The aim of our paper is to uncover the importance of the private value component in art. In the following we focus on the mechanisms by which the private value component is affected. Our identification strategy relies on using insights from recent experimental evidence on the importance of emotions in private value auctions. We proxy for external variation in mood by using the variation in daily sunshine. The motivation stems from

Emotions are important in decision making, and have been shown to

\footnotetext{
${ }^{2}$ Among other distributions, the normal, uniform and exponential distribution satisfy this requirement.
} 
impact the perceived riskiness of decisions (Johnson and Tversky, 1983; Rottenstreich and Hsee, 2001). Loewenstein et al. (2001) look at the role of affect on decision making. They draw on clinical psychology research and show that positive emotional reaction to risky situations often diverges from the cognitive assessment of those risks. They find that people in positive emotional states tend to make more optimistic judgments. Kuhnen and Knutson (2011), test this hypothesis in a financial market setting and find supportive experimental evidence that positive emotional states induce people to take on risk. The mechanism at play is that positive affect reduces the subjective probability distribution of returns. Risk is associated with subjective uncertainty whereby individuals reduce the subjective probability distribution of returns. People in positive emotional states tend to make optimistic judgments about the expected distribution of returns. Risk, as measured by the standard deviation of the probability return distribution is less and subsequently the judgment on the valuation of the object changes.

Emotions have also been studied in auction settings, Capra et al. (2010) find that when inducing bidders with positive emotions in a random $n^{\text {th }}$ price auction experiment, there is a resulting bias in bidding upwards in the induced value condition. Bosman and Riedl (2004) investigate how emotions, induced by an economic shock translate into bidding behavior in a first-price auction. The authors show that inducing negative emotions, bidders bid more aggressively. However, their experimental findings do not lead to any significant difference in bidding behavior induced by positive shocks on subjects and conclude that bidders in a positive emotional state do not change their bidding behavior. The results are supportive of the affective regulation hypothesis, whereby people in a negative mood will take action to improve their mood, whereas people in a positive mood will refrain from changing behavior as a way to prevent changing their affective state. Capra et al. (2010) explains this in detail and look specifically at how mood influences choice. The authors distinguish between how mood can affect the valuation of the object being auctioned as well as affecting the bidding behavior itself. They find no evidence that mood effects willingness to pay, instead it does appear to affect bidding behavior. Thus, the experimental results from Capra et al. (2010) and Bosman and Riedl (2004) stand in partial contrast to each other, but cannot be directly compared since the auction mechanism differ between the two studies. The design of the art 
auctions studied in this paper, theoretically resemble second price auction and thus lays closer to the $n^{\text {th }}$-price auction studied in Capra et al. (2010).

Lerner et al. (2004) study the willingness-to-pay and accept under different emotions. The authors focus on the effect of sadness and disgust and find that inducing negative emotions result in subjects reducing their willingness-to-accept. They suggest that by triggering the emotions of sadness and disgust, subjects overtly want to expel and as a response reduce the willingness-to-accept.

Mood induced changes in behavior are not exclusively found in the laboratory, but several researchers also establish that mood, through local weather conditions, has a significant impact on returns in financial markets. Saunders (1993) studies the New York weather and stock market and shows that on very cloudy days, stock market returns are significantly lower. Hirshleifer and Shumway (2003) extend the sample and record cloud coverage in the morning at 26 international stock markets, and show that cloud coverage is negatively correlated with returns. They argue that since the effect is present and significant for the pooled sample of stock markets, it can be considered a genuine effect on returns. Interestingly, Goetzmann and Zhu (2005) show that the weather effects do not seem to stem from individual traders, but is instead driven by market makers. This finding is confirmed by Loughran and Schultz (2004) who show that there is no local weather bias with respect to the geographic location of the firm itself.

In addition to the weather effect, Kamstra et al. (2003) show that there is considerable seasonal variation in stock returns that correlate with the length of the day. The authors study several international stock markets at different latitudes that are located in both hemispheres. The evidence shows that the stronger the variation in the length of the day is, the more variation in returns is present. They label it as a seasonal affective disorder (SAD) effect. While it is not the focus of our study, the authors show that on shorter days (with less sunlight), around the winter solstice, depressed mood lowers stock market returns which return to higher levels as the days subsequently become longer again (Kamstra et al., 2003).

Similarly, behavioral changes due to the variation in weather could be driven by a projection bias. The projection bias captures a decision maker's exaggerated belief that his current taste also represents his future taste and therefore leads to biased decisions (Loewenstein et al., 2003). Conlin et al. 
(2007) study the relation between catalog orders for clothing and the local weather and find that the quantity of clothing returned is inversely related to temperature.

We can use the existence of the common value component to further test our hypothesis. The common value component represents the future, but unknown, resale value of the painting. The value of the common value component is independent of any temporary factor affecting the private value component. During the sample period that we study, the two major auction houses in London, Sotheby's and Christie's, formed a cartel to jointly set the commission rates received from sellers (Ashenfelter and Graddy, 2005). Christie's publicly announced the increase in commission rate in March 1995, and Sotheby's followed to make a similar announcement shortly thereafter. In 1996, the UK Office of Fair Trading announced that informal inquiries were being made and later it was decided that the two auction houses were in violation of Britain's Fair Trading Act of 1973 and the Competition Act of 1980 (Ashenfelter and Graddy, 2005). The cartel was active from September 1, 1995 to February 2, 2000.

Since the auction houses publicly announced the increased commission rates charged to sellers, all bidders were aware of the institutional change that they faced. Thus the sellers could pass the increased commission to buyers by increasing estimates. Bidders, who buy for investment purposes, incorporate the auction house estimate information when bidding and should be bidding more aggressively as a result. This would shift prices upward as long as buyers put a large emphasis on the common value component. The private value component on the other hand will remain unaffected by variation in the resale value.

In sum, we expect to see two effects on auction prices. When the relative importance of the private value component is high, then good weather should capture variation in mood and thus also higher prices, in accordance with Capra et al. (2010). However, when the relative importance of the private value component is low, the prices of paintings transacted during the cartel should be significantly different from the non-cartel period. 


\subsection{Data}

In this section we introduce our weather data as well as our auction records.

\subsubsection{Weather variables}

We collect intra-daily weather data for London from the British Atmospheric Data Centre (BADC) ${ }^{3}$ that is associated with the Natural Environment Research Council (NERC). We choose to record weather data from the Heathrow weather station (station id 708), since this station has been in continued operation for over half a century. Other weather stations have either opened, closed, or do only record a subset of the weather variables used in our study. From the weather data we extract daily observations on the minimum, and maximum temperature $\left({ }^{\circ} \mathrm{C}\right)$, precipitation $(\mathrm{mm})$, and sunshine (hours).

The vast majority of the studies on weather effects on the stock market, use cloud coverage as their main weather indicator (see for instance Saunders, 1993; Loughran and Schultz, 2004; Kliger and Levy, 2003). These studies have shown that variation in cloud coverage is a good proxy for mood variation. Hirshleifer and Shumway (2003) further shows that after controlling for sunshine, rain and snow become irrelevant for returns. Since we do not observe cloud coverage through the weather data available to us, we use a comparable measure, the hours of sunshine as our main weather indicator. The hours of hours of sunshine should be strongly negatively correlated with cloud coverage.

In Figure 4.1 we plot the monthly average hours of sunshine during our sample period. The plot indicates that there is a significant cyclical behavior of the hours of sunshine in London. To control for seasonal changes in weather, we calculate the distribution of sunshine hours for each month of the year separately using weather data going back to 1957 . We use the distribution of the month specific sunshine hours to determine a threshold that defines what a good day constitutes. Using this method, a good day in January will be different from a good day in e.g. June.

The surveyed literature clearly shows that there are much stronger mood effects on exceptional compared to just normal days (see for instance Saunders, 1993). As a consequence we define a good weather day, as opposed to

3 The data as well as an overview of all variables can be accessed at http://badc.nerc.ac.uk/data/ukmo-midas/ 


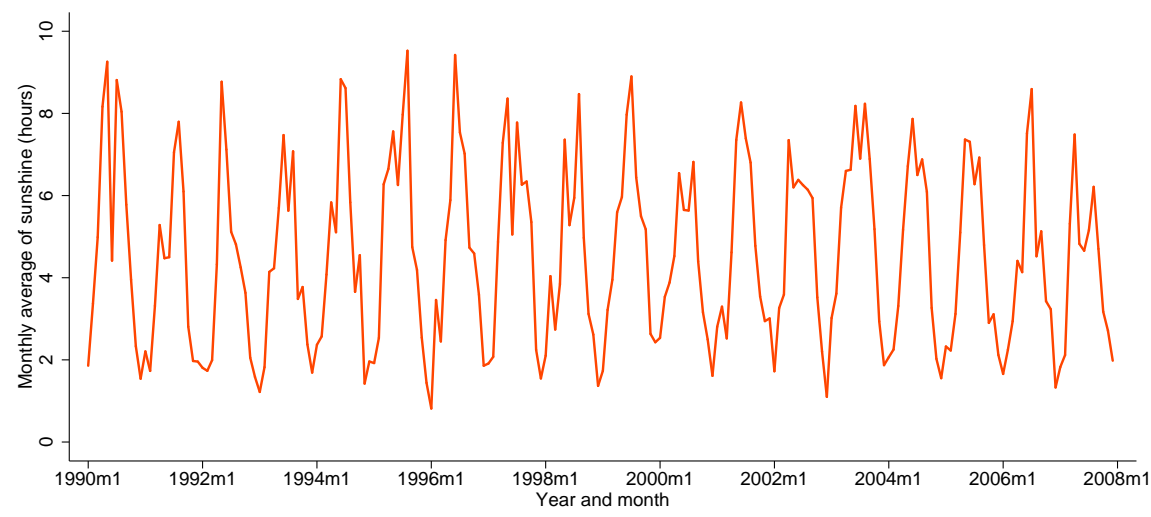

Figure 4.1: Monthly average of the daily hours of sunshine over our sample period.

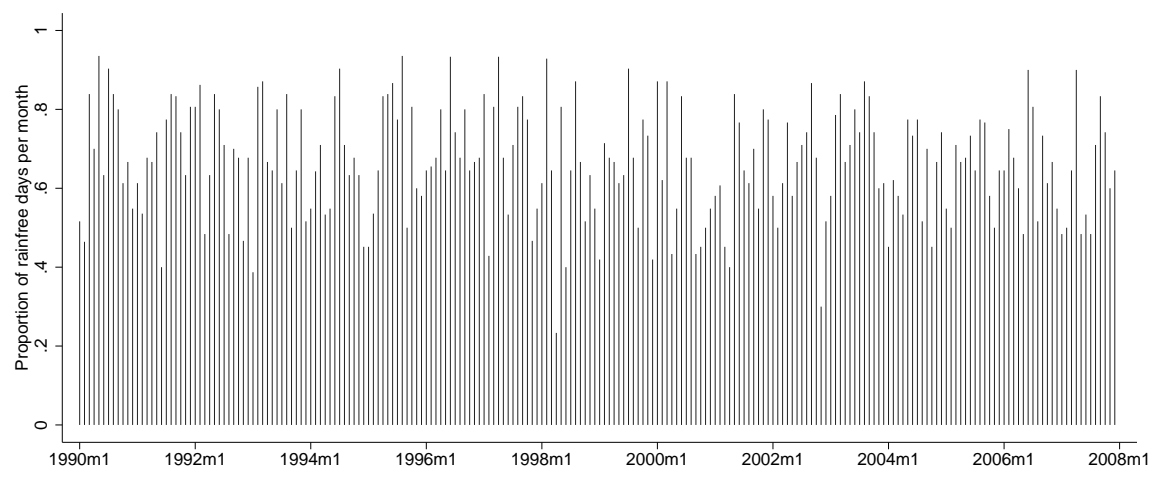

Figure 4.2: Proportion of rain free days per month.

a normal weather day, as being one of the $10 \%$ best days in each month in terms of the hours of sunshine. We set our constructed variable to 1 when a day is in the top category and 0 otherwise.

The amount of rain in London is considerable, as can clearly be seen in Figure 4.2. To make our measure restrictive, we therefore interact our constructed variable with a dummy variable that takes 1 if there is no rain on that day and 0 otherwise. To sum up, our proxy for good weather throughout this paper takes value 1 when there is no rain and the day belongs to the top $10 \%$ sunshine days of that particular month of the year, and zero otherwise. 


\subsubsection{Auction data}

We collect art auction records from the two major auction houses in Britain, Christie's and Sotheby's over the time period between 1990 and 2007. The observations collected are from paintings that have a previously recorded transaction. We record pre-sale estimates, the artist (if known), as well as the following characteristics associated with each object: motive, material, and school.

Due to the presence of some extreme outliers that could be incorrectly recorded values, we observe that the distribution of bids is skewed to the right in the upper tail. This is an empirical issue that is commonly reported in the literature (see, e.g., Marion, 2007, Guerre et al., 2000). One solution is to consider the data-driven scheme introduced by Guerre et al. (2000). By calculating an upper and a lower bound for auction prices using the optimal bandwidth obtained by Silverman's rule of thumb (see Silverman, 1986 and Härdle, 1990) this procedure results in a removal of 26 observations. The optimal width is the width that minimizes the mean integrated squared error if we use a Gaussian kernel and the standard normal distribution as the reference distribution. By this process we remove 26 observations.

In Table 4.1, we report simple summary statistics by weather, cartel and seasons. Results indicate that prices during bad weather days are about $£ 46,000$ higher than those on good weather days. In the next two rows, we report the price difference with and without cartel influence. Interestingly, the summary statistics indicate that the sale prices were lower during the cartel period, compared to the non-cartel period. The seasons show strong variation in prices indicating that there are strong seasonal patterns within the art market. The winter and summer display much higher prices than the spring and autumn. In relative prices however, ${ }^{4}$ the differences are very small, showing that the markup above the estimate is stable across different painting price categories.

Figure 4.3 plots the log transaction prices by weather, cartel, and seasons respectively. The plots reveal that there appears to be little differences between the cartel and non-cartel periods, whereas sales during good weather seem to fetch slightly lower prices. The differences between the four seasons are more pronounced, and sales during winter and summer seem to

\footnotetext{
${ }^{4}$ Relative price $=\frac{\text { Price }}{\frac{\text { High estimate }+ \text { Low estimate }}{2}}$.
} 
capture higher prices than those during spring and autumn. Note that these are unconditional densities and in the next section we empirically test the differences in sale prices due to good weather and the cartel.

\begin{tabular}{lccccc}
\hline Variable & Number of & \multicolumn{3}{c}{ Paintings Sold } & \multicolumn{2}{c}{ Sale price } & Relative price \\
\cline { 3 - 6 } & Sessions & Number & Percentage & Mean & Mean \\
\hline Good weather & 81 & 883 & .669 & $92,151.79$ & 1.398 \\
& & & $(.471)$ & $(329,895.7)$ & $(1.019)$ \\
Bad weather & 708 & 9,095 & .663 & $139,556.4$ & 1.436 \\
& & & $. .473)$ & $(540,063.9)$ & $(1.535)$ \\
During cartel & 204 & 2,147 & .646 & $103,318.6$ & 1.414 \\
& & & $(.478)$ & $(355,332.3)$ & $(2.148)$ \\
Pre- and post-cartel & 585 & 7,831 & .669 & $144,146.4$ & 1.437 \\
& & & $. .471)$ & $(562,387.6)$ & $(1.261)$ \\
Spring & 169 & 1,582 & .710 & $36,899.49$ & 1.459 \\
& & & $(.454)$ & $(91,521.11)$ & $(1.232)$ \\
Summer & 277 & 4,166 & .658 & $160,485.8$ & 1.427 \\
& & & $(.474)$ & $(583,141.9)$ & $(1.377)$ \\
Autumn & \multirow{2}{*}{204} & 1,652 & .625 & $61,364.33$ & 1.360 \\
& & & $. .484)$ & $(169,690.5)$ & $(1.030)$ \\
Winter & 139 & 2,578 & .673 & $202,599.9$ & 1.470 \\
& & & $(.673)$ & $(692,119.6)$ & $(1.997)$ \\
\hline
\end{tabular}

Standard deviations are in parentheses.

Table 4.1: Summary statistics by weather, cartel and season.

\begin{tabular}{lcccc}
\hline Variable & Mean & Std dev & Min & Max \\
\hline Price & 135,361 & 525,031 & 115 & $19,803,750$ \\
Mid-point estimate & 106,194 & 415,207 & 150 & $16,000,000$ \\
Good weather & .088 & .284 & 0 & 1 \\
Cartel & .215 & .411 & 0 & 1 \\
Old master & .300 & .458 & 0 & 1 \\
European 19 $9^{\text {th }}$ century & .099 & .299 & 0 & 1 \\
Modern impressionist & .322 & .467 & 0 & 1 \\
Other & .197 & .398 & 0 & 1 \\
Size $\left(m^{2}\right)$ & .566 & 1.232 & .002 & 40.649 \\
Auction house 1 & .563 & .496 & 0 & 1 \\
Auction house 2 & .437 & .496 & 0 & 1 \\
Spring & .159 & .364 & 0 & 1 \\
Summer & .417 & .493 & 0 & 1 \\
Autumn & .166 & .372 & 0 & 1 \\
Winter & .258 & .438 & 0 & 1 \\
FTSE100 & -.000 & .005 & -.026 & .034 \\
\hline
\end{tabular}

Table 4.2: Summary statistics of regression variables. 

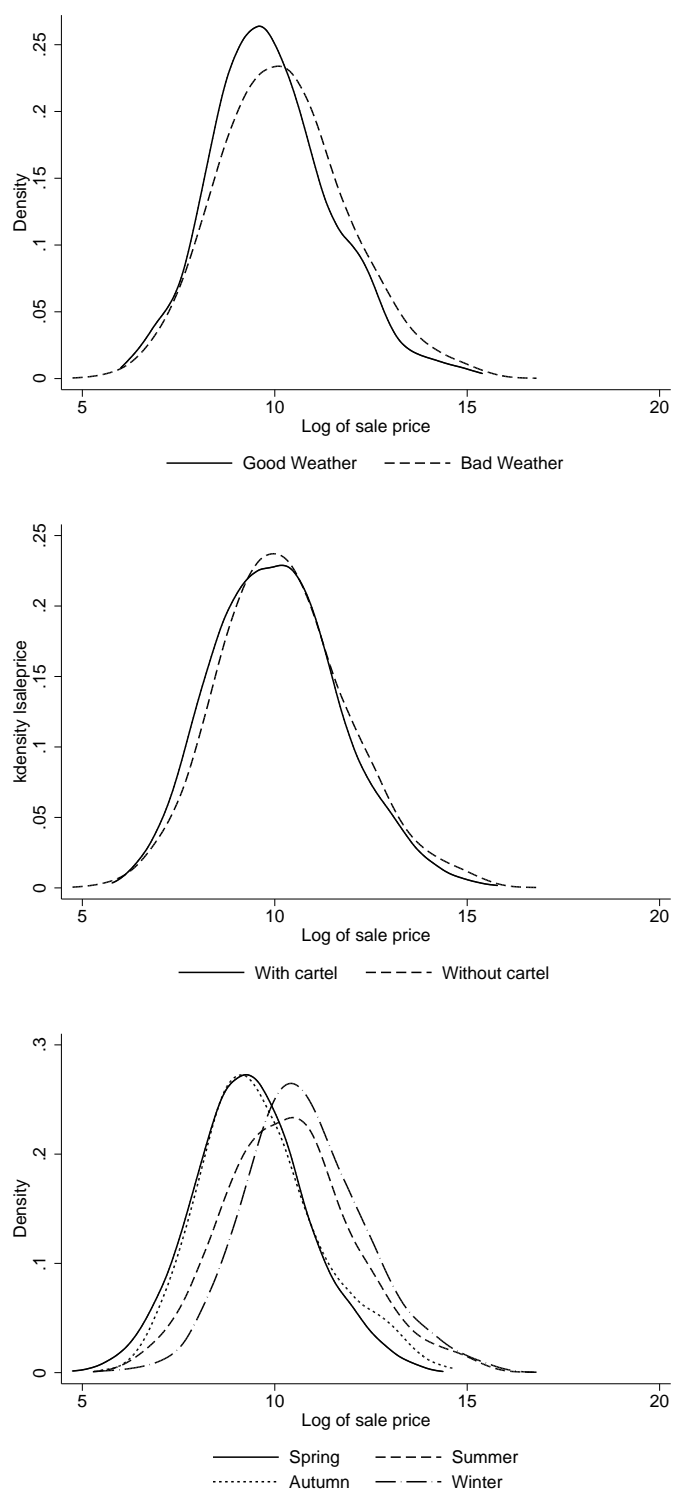

Figure 4.3: Sale prices by weather, cartel and season. 


\subsection{Results}

\subsubsection{Number of Paintings sold}

The art market suffers from selection and liquidity problems as noted frequently in the literature (for instance, Mei and Moses, 2002; Goetzmann, 1993). Some paintings that are put up for sale do not meet the reserve price and remain unsold. We therefore analyze the variation in the number of transacted paintings and how it is influenced by good weather days as well as the presence of the cartel. We define a session as all paintings that are observed and offered on a particular day for each of the auction houses in our study. We perform this analysis using the absolute number of paintings sold as well as the relative ratio of sold-to-offered. Our specifications are as follows,

$$
\operatorname{sold}_{a t}=\phi o f f e r e d a t+W \Gamma+M \Theta+\eta_{a t}
$$

where $W$ and $M$ are controls for the weather and the presence of cartels and the seasonal and market characteristics. The variables sold and offered are the number of paintings sold and the number of paintings offered for sale by an auction house $a$ on a given day $t$ respectively.

The results are presented in Table 4.3 and show three separate specifications. The first two columns concern the absolute number of paintings sold and are estimated by a negative binomial regression and OLS. The results show no sign of variation in the number of sold paintings arising from either good weather or the cartel. When we run our estimation using the relative number paintings sold, presented in column 3, we see that our good weather proxy is negative and significant at the $10 \%$ level. This shows some sign of good weather having a negative effect on the probability of sales and could signal that there are in fact outside opportunities resulting in less attendance and may lead to less aggressive bidding. While we cannot observe the number of actual or potential bidders in these auctions, Ashenfelter (1989) notes that there does not seem to be a link between then number of bidders and the percentage of items bought-in and argues that the actual buy-in rates are unlikely to be explained by the factors used in the optimal auctions literature. While we cannot fully rule out such effects, our main concern is the effect that mood has on prices. Further, if fewer paintings sell, due to less aggressive bidding, it should in general lower 
prices during good weather and thus works in the opposite direction to our hypothesis.

\begin{tabular}{|c|c|c|c|}
\hline & \multicolumn{2}{|c|}{$\begin{array}{l}\text { Number of paintings } \\
\text { sold }\end{array}$} & \multirow{2}{*}{$\begin{array}{c}\begin{array}{l}\text { Proportion of } \\
\text { paintings sold }\end{array} \\
\text { OLS }\end{array}$} \\
\hline & Negative binomial & OLS & \\
\hline Number of paintings offered for sale & $\begin{array}{c}0.043^{* * *} \\
(0.002)\end{array}$ & $\begin{array}{c}0.699^{* * *} \\
(0.016)\end{array}$ & \\
\hline Good weather $\left(\beta_{1}\right)$ & $\begin{array}{c}0.027 \\
(0.224)\end{array}$ & $\begin{array}{l}-1.203 \\
(1.539)\end{array}$ & $\begin{array}{l}-0.136^{*} \\
(0.078)\end{array}$ \\
\hline Cartel $\left(\beta_{2}\right)$ & $\begin{array}{l}-0.032 \\
(0.226)\end{array}$ & $\begin{array}{l}-1.586 \\
(1.142)\end{array}$ & $\begin{array}{l}-0.047 \\
(0.087)\end{array}$ \\
\hline Spring $\left(\beta_{3}\right)$ & $\begin{array}{c}0.032 \\
(0.081)\end{array}$ & $\begin{array}{l}1.110^{*} \\
(0.619)\end{array}$ & $\begin{array}{c}0.038 \\
(0.032)\end{array}$ \\
\hline Summer $\left(\beta_{4}\right)$ & $\begin{array}{c}0.053 \\
(0.069)\end{array}$ & $\begin{array}{l}-0.284 \\
(0.419)\end{array}$ & $\begin{array}{l}-0.022 \\
(0.025)\end{array}$ \\
\hline Autumn $\left(\beta_{5}\right)$ & $\begin{array}{l}-0.002 \\
(0.076)\end{array}$ & $\begin{array}{l}-0.147 \\
(0.428)\end{array}$ & $\begin{array}{l}-0.045 \\
(0.028)\end{array}$ \\
\hline Spring $\times$ Good weather $\left(\beta_{6}\right)$ & $\begin{array}{l}-0.168 \\
(0.270)\end{array}$ & $\begin{array}{c}0.703 \\
(1.632)\end{array}$ & $\begin{array}{c}0.129 \\
(0.103)\end{array}$ \\
\hline Summer $\times$ Good weather $\left(\beta_{7}\right)$ & $\begin{array}{c}0.072 \\
(0.258)\end{array}$ & $\begin{array}{c}2.045 \\
(1.677)\end{array}$ & $\begin{array}{l}0.174^{*} \\
(0.090)\end{array}$ \\
\hline Autumn $\times$ Good weather $\left(\beta_{8}\right)$ & $\begin{array}{c}0.034 \\
(0.274)\end{array}$ & $\begin{array}{c}1.625 \\
(1.606)\end{array}$ & $\begin{array}{c}0.152 \\
(0.096)\end{array}$ \\
\hline Salehouse 2 & $\begin{array}{l}-0.189^{* * *} \\
(0.049)\end{array}$ & $\begin{array}{l}-0.153 \\
(0.254)\end{array}$ & $\begin{array}{l}-0.010 \\
(0.018)\end{array}$ \\
\hline Constant & $\begin{array}{l}1.354^{* * *} \\
(0.114)\end{array}$ & $\begin{array}{l}-0.846 \\
(0.610)\end{array}$ & $\begin{array}{c}0.661^{* * *} \\
(0.041)\end{array}$ \\
\hline Year effects & Yes & Yes & Yes \\
\hline F Test (p-value) & & & \\
\hline $\begin{array}{l}H_{0}: \beta_{1}+\beta_{6}=0 \\
H_{0}: \beta_{1}+\beta_{7}=0 \\
H_{0}: \beta_{1}+\beta_{8}=0\end{array}$ & $\begin{array}{l}0.351 \\
0.434 \\
0.695\end{array}$ & $\begin{array}{l}0.394 \\
0.182 \\
0.407\end{array}$ & $\begin{array}{l}0.929 \\
0.410 \\
0.762\end{array}$ \\
\hline $\begin{array}{l}\text { Observations } \\
\text { R-squared }\end{array}$ & 789 & $\begin{array}{l}789 \\
0.96\end{array}$ & $\begin{array}{c}789 \\
0.064\end{array}$ \\
\hline $\begin{array}{l}\text { Robust standard errors in parentheses } \\
\text {***} p<0.01,{ }^{* *} p<0.05,{ }^{*} p<0.1\end{array}$ & & & \\
\hline
\end{tabular}

Table 4.3: Number of paintings sold per session.

\subsubsection{The value of art}

To assess whether there is an effect of mood on auction prices we take two approaches. First, we estimate the log price on the good weather and cartel dummies, with a set of controls using a linear regression model. Second, we employ quantile regression to study how the relative importance of the private and common value components vary with the distribution of prices. This approach also enables us to see whether in fact the cartel and mood affect different paintings through the relative importance of the private and common value components as discussed in Section 2. 
Our first empirical specification is as follows:

$$
y_{i}=W B+P \Gamma+M \Phi+\epsilon_{i}
$$

where our dependent variable, $y_{i}$, is the log of the sales price. The independent variables include three sets of variables. $W$ contains the variables of interest, good weather and the cartel; $P$ contains the controls for for painting characteristics; and $M$ contains the control for seasonal and market characteristics. In specific, the painting characteristics consist of a set of dummy variables to identify if the painting was created by a 'top western painter', the dummy variables for the painting categories, the size of the painting in square-meters, and an auction house dummy. For market controls we include FTSE100 returns and year effects. The logic behind controlling for three day past FTSE100 returns is that it can capture any potential outside variation in mood implied by short-term swings in the stock market. Detailed descriptions of the construction of these variables are provided in Appendix B.

We report the results from the linear regressions in Table 4.4. All specifications are estimated using robust standard errors with different sets of controls. Through all specifications it is clearly visible that there is no effect from either the cartel or good weather. By interacting good weather with a particular season we analyze whether there are seasonal differences in the good weather effect. We do this since the weather pattern in London is highly seasonal, as shown in Figure 4.1. The base coefficient on good weather $\left(\beta_{1}\right)$, thus only captures the good weather effect from sales occurring during winter. We test for significance of good weather during other seasons with an F-test on the sum of the season specific good weather coefficient and our base case, for instance for the spring this represents a test of $\beta_{1}+\beta_{6}=0$. There does not appear to be any good weather effect. Studying the type of art that is sold, European and 19th century art as well as modern and impressionist art yields low prices compared to the left out category, uncategorized or 'other' paintings. We also control for a selection of important painters in the last two columns. In our sample of sold paintings $14 \%$ or 1,370 out of 9,785 were attributed to top artists. The list of painters is presented in Appendix A.

Next, we employ quantile regression as proposed by Koenker and Basset (1982). The quantile regression allows us to assess how good weather, our 


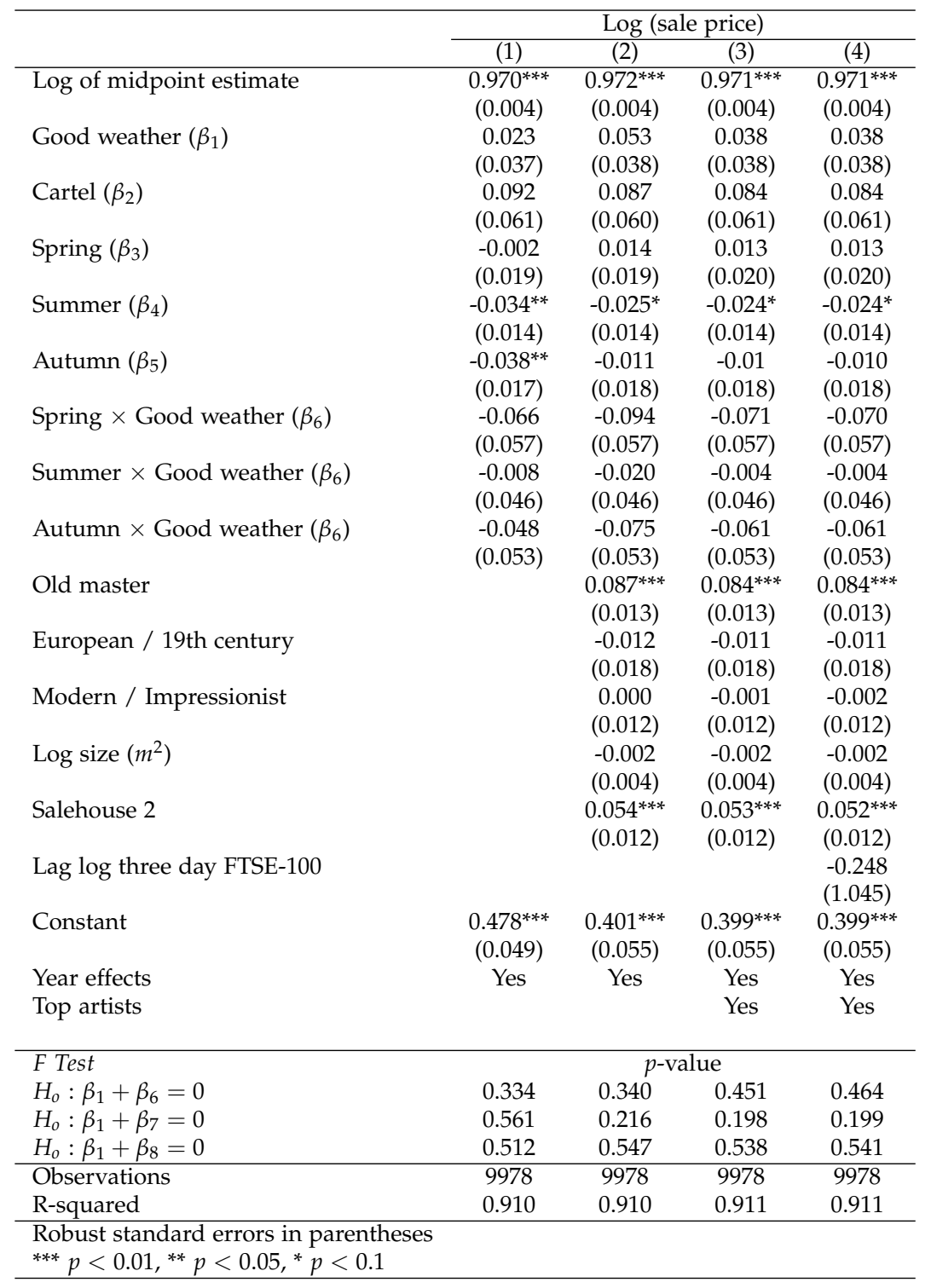

Table 4.4: Regression results with robust standard errors. 
proxy for good mood, affects log prices at different quantiles of the distribution. Table 4.5 reports the results of the quantile regression. In Panel A, the quantile regression reveals that in fact both good weather and the cartel have a significant impact on sales prices but in different quantiles. In the low end of the price distribution we observe that good weather is significant at the $20^{\text {th }}$ and $30^{\text {th }}$ quantile, as well as marginally at the $60^{\text {th }}$ quantile during winter and at the $10^{\text {th }}$ and $20^{\text {th }}$ quantiles, as well as marginally at the $90^{\text {th }}$ quantile during summer, whereas the cartel remains insignificant. As we move up the price distribution we observe that the significance of good weather vanishes but at the same time that the coefficient of cartel picks up significance.

Adding additional controls for important painters in Panel B, we see that the magnitude of the good weather effect weakens, but that it remains significant at the low end during summer and winter. The cartel effect remains strongly significant. The cartel dummy should only pick up significance if paintings indeed are bought for investment purposes and therefore the common value component is strong enough. Further, our evidence for the weather effect support our hypothesis of paintings entailing both a private and a common value component. ${ }^{5}$

\subsection{Discussion}

In this paper we study how mood affects art auction prices, as proxied by variation in local weather. We find that mood affects the lower end of the price distribution. We use the existence of a cartel between the auction houses to proxy for variation in the common value component. Our evidence shows that it is only the upper end of the price distribution that is affected by the cartel. Our findings support the evidence by Capra et al. (2010) by showing that there is a, although relatively weak, mood effect on auction prices.

The role of emotions in economic decision making is not yet fully understood. Experimental evidence has shown that mood affects decision mak-

\footnotetext{
${ }^{5}$ As a robustness check we rerun our regressions using a broader good weather definition. We redefine good weather to include the $15 \%$ best days in each month in terms of the hours of sunshine and no rain. Results indicate that coefficients of good weather in general show the same direction as in top $10 \%$ of days but are less statistically significant with as well as without artist dummies. The cartel effect remains statistically significant at the higher quantiles. We do not report these results but can be provided upon request.
} 


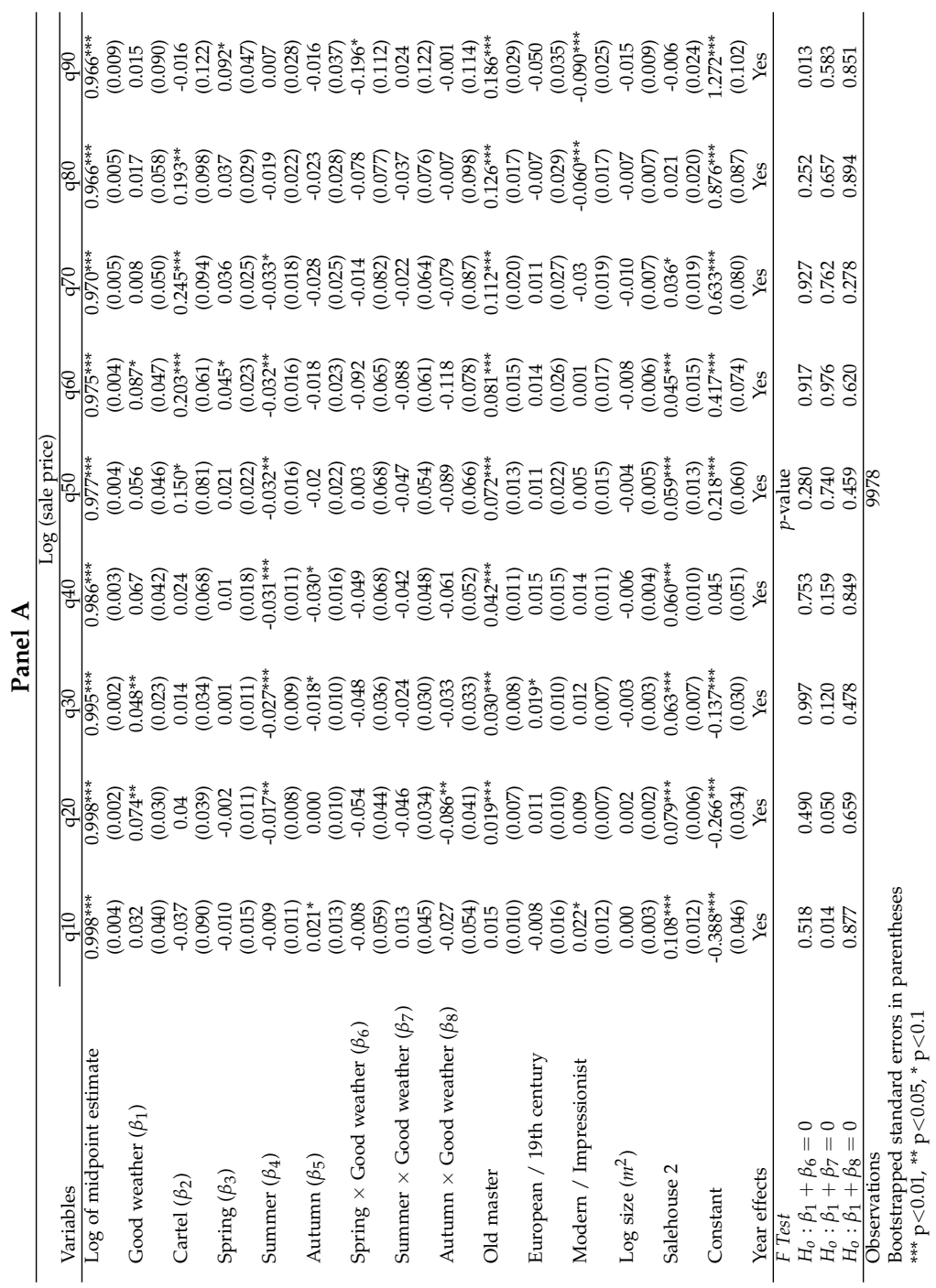




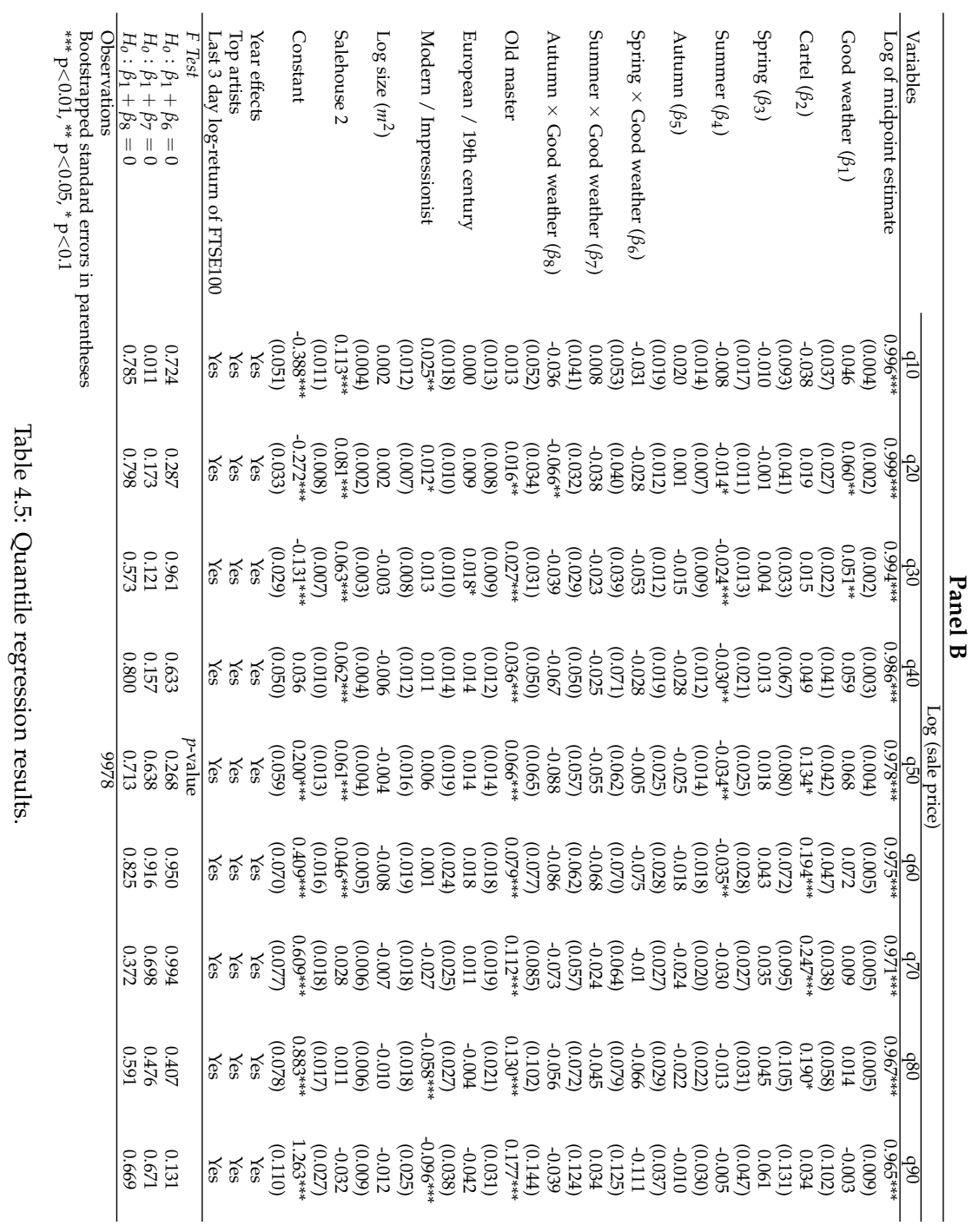


ing. Our study identifies this effect also in a field setting. At the same time, we show that the effect of mood induced behavior disappears as we move up the price distribution and the cartel effect becomes significant. This does not suggest that the mood induced behavior vanishes when moving up the quantiles, instead it could be driven by the reduction of the importance of the private value component and thus we can no longer capture the effect of mood on auction prices.

Our research suggests that there are important insights to be made by understanding the role of emotions in auctions. The implications of our results are important to art auction participants. By understanding the nature of the good being sold, bidders can make informed judgments about the value that they attach to an item. Our findings highlight the importance of the source of the value attached to an item and its relation to the relative importance of the private and common value components. By understanding emotions in decision making better we can improve our understanding of individual behavior in markets beyond auctions. 


\subsection{Appendix: Artists}

\begin{tabular}{llll} 
Important painters of the history of western painting & & \\
\hline Albrecht Durer & Fra Angelico & James Ensor & Paul Gauguin \\
Amedeo Modigliani & Francis Bacon & James Mcneill Whistler & Paul Klee \\
Andrea Mantegna & Francisco de Goya & Jan van Eyck & Peter Paul Rubens \\
Andy Warhol & Francisco de Zurbaran & Jan Vermeer & Piero Della Francesca \\
Arshille Gorky & Frans Hals & Jasper Johns & Pierre-Auguste Renoir \\
Artemisia Gentileschi & Franz Marc & Jean Francois Millet & Pieter Bruegel the Elder \\
Camille Corot & Frederick Edwin Church & Jean-Antoine Watteau & Raphael \\
Caravaggio & Frida Kahlo & Jean-Auguste-Dominique Ingres & Rembrandt van Rijn \\
Caspar David Friedrich & Georges Braque & Jean-Michel Basquiat & Rene Magritte \\
Cimabue & Georges de La Tour & Joachim Patinir & Roger van der Weyden \\
Claude Lorrain & Georges Seurat & Joan Miro & Roy Lichtenstein \\
Claude Monet & Georgia O'Keefe & John Constable & Salvador Dali \\
Dante Gabriel Rossetti & Gerhard Richter & Joseph Mallord William Turner & Sandro Botticelli \\
David Hockney & Giorgio de Chirico & Kazimir Malevich & Simone Martini \\
Diego Velazquez & Giorgione & Leonardo da Vinci & Theodore Gericault \\
Duccio da Buonisegna & Giotto di Bondone & Lucio Fontana & Tintoretto \\
Edgar Degas & Gustav Klimt & Marc Chagall & Titian \\
Edouard Manet & Gustave Courbet & Marcel Duchamp & Tomasso Masaccio \\
Edvard Munch & Gustave Moreau & Mark Rothko & Umberto Boccioni \\
Edward Hopper & Hans Holbein the Younger & Max Ernst & Uincent van Gogh \\
Egon Schiele & Hans Memling & Michelangelo Buonarroti & Wassily Kandinsky \\
El Greco & Henri Matisse & Nicolas Poussin & Willem de Kooning \\
El Lissitzky & Hieronymus Bosch & Pablo Picasso & William Blake \\
Eugene Delacroix & Jackson Pollock & Paolo Uccello & William Hogarth \\
Fernand Leger & Jacques-Louis David & Paul Cezanne & Winslow Homer \\
\hline Source: http://www.theartwolf.com/articles/most-important-painters.htm Wolf (2011) &
\end{tabular}

\subsection{Appendix: Construction of variables}

In this appendix we describe the construction of our variables used in the empirical analysis.

- Good weather: We construct the good weather dummy variable with the following procedure,

1. Using daily data from the Heathrow weather station (id 708) from the period between 1957 to 2007, we construct month specific distributions of the hours of sunshine. From these distributions, we infer a $10 \%$ cutoff value to identify the requirement for a good day.

2. We compare each auction sale day in our sample from 1990 to 2007 with these cutoff values to determine whether a sale was conducted on a good or bad day.

3. To create the good weather variable, we interact good sunshine with a variable taking value 1 of there is no rain and zero otherwise. 
- Cartel: The variable takes value 1 for every sale that occurs within the cartel period between September 1, 1995 and February 2, 2000.

- Seasons: We define the seasons as,

- Winter: December, January, and February.

- Spring: March, April, and May.

- Summer: June, July, and August.

- Autumn: September, October, and November.

- Mid-point estimate dummies: We calculate the mid-point estimate for each painting. We then construct five dummy variables for the different ranges of estimates, from $0 \%$ to $20 \%, 21 \%$ to $40 \%, 41 \%$ to $60 \%, 61 \%$ to $80 \%$, as well as $81 \%$ to $100 \%$. We use these variables to make sure that paintings eith low and high estimates are not unevenly distributed across qunatiles in the qunatile regression.

- Painting category: We categorize the paintings on sale into one of the following categories,

- Old master

- European / 19th century

- Modern / Impressionist

- Other

- FTSE100 returns (lagged 3 day average): We calculate the one day lagged three day average daily log return of the FTSE100 to control for any outside opportunities that investors enjoy at the time of the sale.

- Painting size: We include two variables, height and width as further control variables. Both are measured in centimeter.

- Top 101 artists: To control for the effect of master pieces, we create dummy variables for a list (Appendix A) of top western painters. 



\section{Chapter 5}

\section{Incentives in prediction markets}

\subsection{Introduction ${ }^{1}$}

Prediction markets serve as popular devices to aggregate beliefs on the outcome of future events into prices. A contract pays out for instance $\$ 1$ if an event occurs and $\$ 0$ otherwise. Traders buy and sell the contracts and thereby determine market prices. The price at which the market clears can be interpreted as the likelihood of an event to occur. The idea traces back to 1945 when Friedrich von Hayek asserted that "in a system where the knowledge of relevant facts are dispersed among many people, prices can act to coordinate the separate actions of different people" (Hayek, 1945, p. 526).

Motivated by this idea, a group of researchers initiated the Iowa Electronic Markets with the aim to forecast the outcome of the 1988 U.S. Presidential election (Forsythe et al., 1992). This effort as well as subsequent prediction markets have shown an astonishing level of predictive power and can thus aid in forecasting and subsequently decision making (Wolfers and Zitzewitz, 2004). Moreover, the price dynamics in prediction markets are found to closely match that of a dynamic binary option model (Majumder et al., 2009).

The accuracy in its performance has induced several corporations to implement prediction markets to predict outcomes of uncertain future events such as updates in macroeconomic statistics (Leigh and Wolfers, 2007) and corporate sales figures (Chen and Plott, 2002). In addition, prediction markets have been experimentally applied to predict the success of new drugs,

${ }^{1}$ This chapter is based on 'Incentives in prediction markets', published as Peeters and Wolk (2012). We thank Stephan Smeekes and Rene Saran for useful advices and comments. 
the number of software patches issued, as well as for production allocation decisions (Kiviat, 2004; Hahn and Tetlock, 2006).

Regrettably, legal restrictions on Internet gambling limit the implementation in many jurisdictions, including the United States (Arrow et al., 2008). One way of dealing with these restrictions is to remove monetary incentives, and let traders bet without any financial gains at stake. However, there are several reasons to doubt that markets without monetary incentives aggregate information similarly to markets with such incentives. First, the use of money may affect the cognitive exertion. Second, the motivational focus may be affected by incentives resulting in a shift from intrinsic motivation to extrinsic motivation in revealing ones true beliefs about the likelihood of a future event. Third, experiments have shown that individuals are unable to predict their own response to a stimulus in a situation where no monetary stakes are present as compared to a situation where they are present (Read, 2005). Finally, differences in performance between the two markets can arise from the lack of incentives for marginal traders to participate in play-money markets. ${ }^{2}$

Despite of the possible problems described here, several prediction markets exist on the Internet that operate without monetary incentives. ${ }^{3}$ Initial evidence on the predictive capacity of these markets is positive (Pennock et al., 2001; Servan-Schreiber et al., 2004). However, the evidence is based on comparing point predictions with actual outcomes, and thereby the studies do not take the time dimension of the market into account. Hence, it remains yet unclear whether the information from the public is absorbed coherently in markets where traders bet with play-money compared to markets run with real-money. Thus, investigating the time dimension is of significant importance in assessing the viability of play-money markets as an alternative to real-money markets.

In this paper we study the co-movement between prediction markets based on real- and play-money that were run simultaneously. We exploit the fact that the play-money market was set up to constantly mimick the price of the real-money market to test whether, despite the imposed price

\footnotetext{
${ }^{2}$ The success of prediction markets is commonly attributed to the existence of marginal traders. These are investors who do not suffer from judgmental biases and exploit any arbitrage opportunity that less informed traders leave in the market (Forsythe et al., 1992). As long as a single marginal trader is present, asset prices reflect their fair value.

${ }^{3}$ Prominent examples include the Hollywood Stock Exchange (http:/ /www.hsx.com) and FTPredict (http://www.ftpredict.com).
} 
reversion toward the real-money market, the markets co-move or not.

The paper is outlined as follows. Section two introduces the data and the institutional designs of the two markets we study. It is followed by section three where we conduct the empirical study. Finally, section four discusses the implications of our results and concludes.

\subsection{Data}

We collect daily closing prices on the United States presidential election and primaries in 2008 from two different prediction market operators: Intrade using real-money as the medium of exchange and FTPredict using play-money. ${ }^{4}$ Both markets are very similar and run on the same software platform with, apart from monetary incentives, only minor design differences.

Traders' submit bids and asks when they intend to trade a contract. The order is then placed either in the order queue or as a limit order which is executed immediately. In this way the traders' determine a market price for each contract. In total, 82 time series from four different markets covering the 2008 primaries and general election in the United States between October 18, 2007 and May 24, 2008. The four markets concern guesses on the Democratic party nominee, the Republican party nominee, the individual election winner, and the winning party. In the Appendix we present a complete list of all contracts in the study.

All contracts analyzed in this study are of the winner-takes-all type. This means that for each market only one contract will end at a price of 100 and all others at a price of 0 . When the market terminates, the full amount is paid out to the participants holding the winning position, either in real-money or in play-money.

While both markets incorporate commission fees, their size vary slightly. In the play-money market the commission fees amount to play- $\$ 0.05$, and in the real-money market, they vary from $\$ 0.00$ to $\$ 0.05$ depending on the type of transaction. A further difference is that the real-money market incorporates a fixed expiry fee of $\$ 0.10$ ( $1 \%$ of the payout rate) for contracts that result in a positive profit (i.e. when a participant holds a winning position).

\footnotetext{
${ }^{4}$ Internet URL of Intrade: http://www.intrade.com and FTPredict: http://www.ftpredict.com. FTPredict has since closed and can be viewed through the Internet archive's Wayback Machine athttp://wayback.archive.org/web/*/http://www.ftpredict.com.
} 
Furthermore, unlike in the real-money market, the play-money market incorporates a ranking board where traders can compare their performance relative to other traders. Finally, there is the obvious difference that trading in the play-money market is not constrained by personal wealth. Instead, players are endowed with play- $\$ 10,000$.

Figure 5.1 illustrates two time series where the prices of the real- and play-money markets follow each other closely. This is remarkable and shows that, despite differences in incentives, prices of both markets seem to reflect the same information. Despite this similarity, we see a notable difference in the traded volume as is exemplified in Figure 5.2: the traded volume in the play-money market is about ten times the volume in the real-money market. The disparity between the market volumes relates to the differences in endowment levels as discussed previously. After all, it is less costly to participate in the play-money market relative to the real-money market.

Many of the 82 contracts in the four markets were introduced more than a year prior to the presidential election and thus many of the candidates covered by the contracts were never actively participating in the nominations and consequently also not actively traded. Thus, the prices of these contracts were not updated as new information on the election emerged. We therefore, in concurrence with other studies on prediction markets, exclude these contracts on grounds of poor observational quality (cf. Tetlock, 2008). More precise, contracts where either the real- or play-money market prices infer a probability of winning of at least $1 \%$ on the first day of our sample period are included in our study. After this selection procedure 23 contract pairs remain. Table 5.1 shows an overview of the contracts and the time span included in our sample.

\begin{tabular}{llcc}
\hline & & \multicolumn{2}{c}{ No. of contracts } \\
\cline { 3 - 4 } Market & Time span $(\mathrm{dd} / \mathrm{mm} / \mathrm{yyyy})$ & All & Selected \\
\hline Democratic nomination & $18 / 10 / 2007-24 / 05 / 2008$ & 28 & 4 \\
Republican nomination & $18 / 10 / 2007-05 / 03 / 2008$ & 33 & 7 \\
Winning individual & $18 / 10 / 2007-24 / 05 / 2008$ & 18 & 9 \\
Winning party & $18 / 10 / 2007-24 / 05 / 2008$ & 3 & 3 \\
\hline
\end{tabular}

Table 5.1: Overview of the contracts. The republican nomination series terminates at March 5 when McCain announced himself as the winner of the republican primaries. 

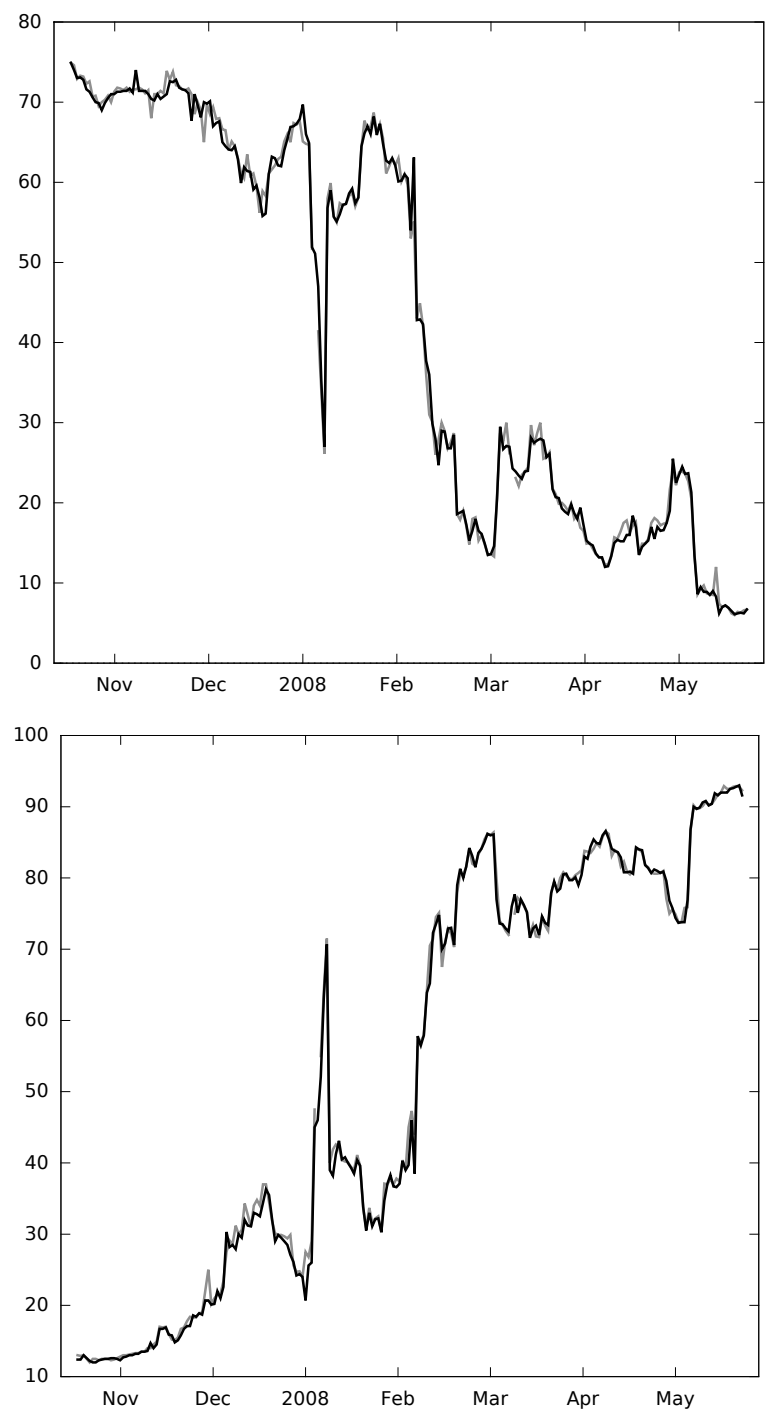

Figure 5.1: Price series. The figure shows the price development of the contracts on Hillary Clinton (top) and Barack Obama (bottom) winning the democratic nomination for the 2008 presidential election. The gray line plots the play-money contract price, while the black line represents the real money market. The series display a pike at the beginning of the primary elections on January 3. After Super Tuesday (February 5) the market estimates ObamaŠs chances of winning the nomination as the presidential candidate of the Democrats higher than for Clinton. 


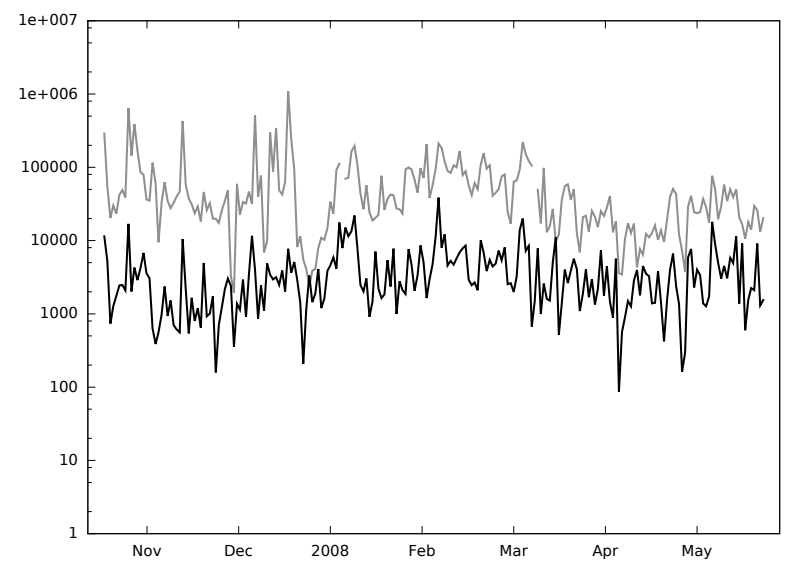

Figure 5.2: Traded volume. The figure shows the total traded volumes for the democratic nomination market, with either real- (black line) or play-money (gray line). Overall, we see that the play-money market exhibits approximately ten-times higher traded volumes than the real-money market. Note that the scale of the volume axis is logarithmic with base 10 .

We study the co-movement between real- and play-money markets by exploiting the decsion to inject liquidity into the play-money market FTPredict by using orders from Intrade. In specific, both individual trades as well as closing price data of FTPredict were aligned with transaction data from Intrade. The manipulation was executed as follows, a trade in the real-money market was carried over to the play-money market with either a volume of one or 101. If the trade resulted from the order queue information that had not yet been transferred to FTPredict the trade would be transferred with a volume of one, and otherwise $101 .^{5}$

\subsection{Empirical study}

A coherent absorption of information between the two markets is reflected in an equal price movement. We apply time series statistics to test whether the two markets cointegrate; that is, co-move as new information is released to the public. Cointegration implies that there is a linear combination of the two variables (Campbell and Perron, 1991) and requires all variables to be integrated of the same order (Enders, 2004). This means that for the bivariate analysis of real- and play-money prediction markets, both contracts of each pair has to be non-stationary, or integrated of order one.

\footnotetext{
${ }^{5}$ The details of the manipulation were provided to us via a representative of Intrade in a series of emails dated October 3, 4 and 12 (2011).
} 


\begin{tabular}{|c|c|c|c|c|c|c|c|}
\hline Market & Contract Pair & Real/Play & Lags & Test Stat. & Crit. Val. & p-value & Non-stationary? \\
\hline Democratic & Clinton & Play & 3 & -0.839 & -2.875 & 0.8054 & Yes \\
\hline \multirow[t]{7}{*}{ Nominee } & & Real & 0 & -0.971 & -2.875 & 0.7635 & Yes \\
\hline & \multirow[t]{2}{*}{ Obama } & Play & 3 & -1.089 & -2.875 & 0.7202 & Yes \\
\hline & & Real & 0 & -0.983 & -2.875 & 0.7595 & Yes \\
\hline & \multirow[t]{2}{*}{ Gore } & Play & 1 & -1.606 & -2.875 & 0.4776 & Yes \\
\hline & & Real & 1 & -1.812 & -2.875 & 0.3742 & Yes \\
\hline & \multirow{2}{*}{ Edwards } & Play & 6 & 0.767 & -2.876 & 0.9933 & Yes \\
\hline & & Real & 6 & -1.062 & -2.875 & 0.7308 & Yes \\
\hline \multirow{14}{*}{$\begin{array}{l}\text { Republican } \\
\text { Nominee }\end{array}$} & \multirow[t]{2}{*}{ Guiliani } & Play & 9 & 0.117 & -2.884 & 0.9659 & Yes \\
\hline & & Real & 0 & 0.202 & -2.882 & 0.9719 & Yes \\
\hline & \multirow[t]{2}{*}{ Romney } & Play & 5 & -1.066 & -2.883 & 0.7278 & Yes \\
\hline & & Real & 3 & -1.215 & -2.882 & 0.6671 & Yes \\
\hline & \multirow[t]{2}{*}{ Thompson (F) } & Play & 1 & -3.650 & -2.883 & 0.0060 & No \\
\hline & & Real & 0 & -4.002 & -2.882 & 0.0019 & No \\
\hline & \multirow[t]{2}{*}{ Paul } & Play & 2 & -0.587 & -2.883 & 0.8687 & Yes \\
\hline & & Real & 3 & -1.057 & -2.882 & 0.7315 & Yes \\
\hline & \multirow[t]{2}{*}{ McCain } & Play & 10 & -0.380 & -2.884 & 0.9081 & Yes \\
\hline & & Real & 10 & -0.229 & -2.882 & 0.9307 & Yes \\
\hline & \multirow[t]{2}{*}{ Rice } & Play & 9 & -1.694 & -2.884 & 0.4317 & Yes \\
\hline & & Real & 4 & -2.279 & -2.882 & 0.1802 & Yes \\
\hline & \multirow[t]{2}{*}{ Huckabee } & Play & 0 & -1.072 & -2.882 & 0.7257 & Yes \\
\hline & & Real & 0 & -1.198 & -2.882 & 0.6744 & Yes \\
\hline \multirow{6}{*}{$\begin{array}{l}\text { Winning } \\
\text { Party }\end{array}$} & \multirow[t]{2}{*}{ Dem. Party } & Play & 2 & -2.605 & -2.875 & 0.0935 & Yes \\
\hline & & Real & 1 & -2.204 & -2.875 & 0.2057 & Yes \\
\hline & \multirow{2}{*}{ Rep. Party } & Play & 1 & -2.386 & -2.875 & 0.1468 & Yes \\
\hline & & Real & 1 & -2.237 & -2.875 & 0.1940 & Yes \\
\hline & \multirow[t]{2}{*}{ Rest of the field } & Play & 5 & -1.701 & -2.875 & 0.4290 & Yes \\
\hline & & Real & 14 & -1.654 & -2.875 & 0.4533 & Yes \\
\hline Winning & Clinton & Play & 2 & -0.786 & -2.875 & 0.8206 & Yes \\
\hline \multirow[t]{17}{*}{ Individual } & & Real & 0 & -0.922 & -2.875 & 0.7798 & Yes \\
\hline & \multirow[t]{2}{*}{ Guiliani } & Play & 14 & -0.991 & -2.877 & 0.7562 & Yes \\
\hline & & Real & 0 & -0.806 & -2.875 & 0.8152 & Yes \\
\hline & \multirow[t]{2}{*}{ Romney } & Play & 3 & -1.060 & -2.875 & 0.7314 & Yes \\
\hline & & Real & 0 & -1.165 & -2.875 & 0.6898 & Yes \\
\hline & \multirow{2}{*}{ Obama } & Play & 3 & -1.179 & -2.875 & 0.6838 & Yes \\
\hline & & Real & 0 & -0.862 & -2.875 & 0.7987 & Yes \\
\hline & \multirow[t]{2}{*}{ Thompson (F) } & Play & 14 & -5.384 & -2.877 & 0.0000 & No \\
\hline & & Real & 11 & -4.819 & -2.875 & 0.0001 & No \\
\hline & \multirow[t]{2}{*}{ Gore } & Play & 14 & -4.529 & -2.877 & 0.0002 & No \\
\hline & & Real & 14 & -5.305 & -2.875 & 0.0000 & No \\
\hline & Paul & Play & 13 & -0.096 & -2.877 & 0.9471 & Yes \\
\hline & & Real & 7 & -1.382 & -2.875 & 0.5908 & Yes \\
\hline & McCain & Play & 1 & -1.054 & -2.875 & 0.7337 & Yes \\
\hline & & Real & 4 & -0.930 & -2.875 & 0.7772 & Yes \\
\hline & Edwards & Play & 13 & 0.109 & -2.877 & 0.9657 & Yes \\
\hline & & Real & 4 & -1.186 & -2.875 & 0.6809 & Yes \\
\hline
\end{tabular}

Table 5.2: Stationarity tests. The stationarity tests were run on levels and with an intercept as the deterministic component. Lags were selected based on the Akaike information criterion. The tests are carried out at the $5 \%$ level.

For the purpose of detecting a non-stationary time series, the Augmented Dickey-Fuller (ADF) test is the proper tool. The ADF test allows for an arbitrary number of lags to be included. To determine the appropriate number of lags, we use the widely adopted Akaike information criterion (AIC). Table 5.2 shows the result of this effort. We apply the test with a deterministic constant and on a 5\% tolerance level.

We find that 20 of the 23 contract pairs have non-stationary price series. For three of the contract pairs we hence conclude that the series are stationary. Important to note is that for all three contract pairs, both the realand play-money market price series are stationary. It would be inaccurate 
to conclude that for these contracts the two markets do not absorb information coherently, there are just too few changes in marginal beliefs to be reflected into a price movement that is sufficiently substantial to generate a non-stationary price series.

Having determined the contract pairs where both contracts are nonstationary, one can test for evidence of cointegration. If cointegration is evident, it means that the real- and play-money contracts are moving together and thus reacting similarly to new information entering the public domain. To test for cointegration we follow the Johansen (1991) procedure and thereby determine a trace statistic to test the null hypothesis of at least one cointegrating relationship (Enders, 2004). Table 5.3 reports the results of the Johansen procedure with a linear time trend and a 5\% tolerance level for the 20 remaining contract pairs.

We find that $20 \%$ of the contract pairs with non-stationary price series do not co-move. This means that for these contracts the play-money market absorbs information from the public systematically different in comparison to the real-money market. This evidence is significant in the light of the price manipulation scheme set up so as to synchronize the two markets. For the remaining $80 \%$ of the contract pairs for which we cannot reject the price series to co-move, we cannot rule out this being driven by the manipulation scheme or by trading behavior across markets just not being sufficiently different to yield systematic differences in the price series. We believe we may conclude that monetary incentives have a fairly massive effect on the information-absorption process in prediction markets.

\subsection{Discussion and conclusion}

We show that a significant fraction of the contracts traded in the real- and play-money markets do not co-move over time even when prices are manipulated to align between the two markets. Our finding hints at the possibility of individual level cognitive biases translating into differences within the information aggregation process. In our analysis we restricted attention to those contracts for which there is an active market, meaning that prices are updated as new information arrives to the public. Thus, our analysis reflects only a portion of the total number of contracts traded and yet conintegration fails for $20 \%$ of the actively traded contract pairs. 


\begin{tabular}{|c|c|c|c|c|c|c|c|}
\hline Market & Contract Pair & Lags & Hypothesis & Trace Stat. & Crit. Val. & $\mathrm{p}$-value & Cointegration? \\
\hline Democratic & Clinton & 1 & None & 45.435 & 15.495 & 0.0000 & Yes \\
\hline \multirow[t]{7}{*}{ Nominee } & & & At most 1 & 0.682 & 3.841 & 0.4089 & \\
\hline & Obama & 5 & None & 31.152 & 15.495 & 0.0001 & Yes \\
\hline & & & At most 1 & 1.135 & 3.841 & 0.2867 & \\
\hline & Gore & 2 & None & 45.238 & 15.495 & 0.0000 & No \\
\hline & & & At most 1 & 4.076 & 3.841 & 0.0435 & \\
\hline & Edwards & 6 & None & 16.580 & 15.495 & 0.0342 & Yes \\
\hline & & & At most 1 & 0.553 & 3.841 & 0.4573 & \\
\hline \multirow{12}{*}{$\begin{array}{l}\text { Republican } \\
\text { Nominee }\end{array}$} & Guiliani & 1 & None & 60.673 & 15.495 & 0.0000 & Yes \\
\hline & & & At most 1 & 0.031 & 3.841 & 0.8612 & \\
\hline & Romney & 6 & None & 15.036 & 15.495 & 0.0585 & No \\
\hline & & & At most 1 & 1.003 & 3.841 & 0.3165 & \\
\hline & Paul & 1 & None & 49.645 & 15.495 & 0.0000 & Yes \\
\hline & & & At most 1 & 0.457 & 3.841 & 0.4988 & \\
\hline & McCain & 1 & None & 72.901 & 15.495 & 0.0000 & Yes \\
\hline & & & At most 1 & 0.299 & 3.841 & 0.5843 & \\
\hline & Rice & 5 & None & 24.118 & 15.495 & 0.0020 & Yes \\
\hline & & & At most 1 & 4.398 & 3.841 & 0.0360 & \\
\hline & Huckabee & 2 & None & 41.534 & 15.495 & 0.0000 & Yes \\
\hline & & & At most 1 & 1.561 & 3.841 & 0.2115 & \\
\hline \multirow{6}{*}{$\begin{array}{l}\text { Winning } \\
\text { Party }\end{array}$} & Dem. Party & 2 & None & 58.004 & 15.495 & 0.0000 & Yes \\
\hline & & & At most 1 & 3.371 & 3.841 & 0.0664 & \\
\hline & Rep. Party & 4 & None & 17.299 & 15.495 & 0.0265 & Yes \\
\hline & & & At most 1 & 3.757 & 3.841 & 0.0526 & \\
\hline & Rest of the field & 4 & None & 7.828 & 15.495 & 0.4840 & No \\
\hline & & & At most 1 & 0.600 & 3.841 & 0.4385 & \\
\hline \multirow{14}{*}{$\begin{array}{l}\text { Winning } \\
\text { Individual }\end{array}$} & Clinton & 1 & None & 84.705 & 15.495 & 0.0000 & Yes \\
\hline & & & At most 1 & 0.657 & 3.841 & 0.4177 & \\
\hline & Guiliani & 3 & None & 14.899 & 15.495 & 0.0613 & No \\
\hline & & & At most 1 & 0.673 & 3.841 & 0.4120 & \\
\hline & Romney & 2 & None & 65.006 & 15.495 & 0.0000 & Yes \\
\hline & & & At most 1 & 1.012 & 3.841 & 0.3143 & \\
\hline & Obama & 4 & None & 42.354 & 15.495 & 0.0000 & Yes \\
\hline & & & At most 1 & 1.544 & 3.841 & 0.2140 & \\
\hline & Paul & 5 & None & 62.528 & 15.495 & 0.0000 & Yes \\
\hline & & & At most 1 & 0.935 & 3.841 & 0.3337 & \\
\hline & McCain & 5 & None & 26.835 & 15.495 & 0.0007 & Yes \\
\hline & & & At most 1 & 0.890 & 3.841 & 0.3456 & \\
\hline & Edwards & 5 & None & 27.509 & 15.495 & 0.0005 & Yes \\
\hline & & & At most 1 & 0.013 & 3.841 & 0.9082 & \\
\hline
\end{tabular}

Table 5.3: Cointegration tests. We perform the Johansen procedure to determine cointegration for the two markets. We calculate the critical value at the $5 \%$-level and compare it to the trace statistic. We conclude that 4 of the 20 pairs with non-stationary price series are not cointegrating.

In sum, the implications of our result are far reaching. The legal restrictions on the operation of markets with monetary incentives leave prediction markets unexploited in many instances where they can improve forecasting. We show that by reverting to play-money markets it is not guaranteed that the information absorption mechanism works as if one would implement the market with monetary incentives. The elimination of monetary incentives, in response to legal restrictions on Internet gambling, may result in an inferior mechanism to predict future events. 



\section{Chapter 6}

\section{Conclusion}

The research presented in this dissertation directly relates to the interplay between individuals and markets and the feedback effects that are generated between them. In particular, through four different market settings, we study learning and experience, individual and market behavior, as well as the role of incentives. In the three sections below, we outline the main findings as well as the wider implications of our results.

Overall, this dissertation shows that incentives affect behavior and that they play an important role in the formation and development of markets. Enhancing our understanding of what determines market behavior, as well as defining proper incentives, is a vital step in the development of market institutions. The studies presented in this dissertation provide four separate perspectives on the economic behavior of individuals and markets.

\section{Learning and experience}

In chapter three, we study repeated bidding in auctions and show that bidders do not follow a weakly dominant strategy throughout their participation in the auction market. Specifically, we show that bidders learn to take the option value of future auctions into account. The learning process makes bidders reduce their bids with $10 \%$ to $20 \%$ in the course of their first five auctions. This finding is significant for the design of auction markets as well as for potential bidders.

Auction operators can benefit from the inflow of new bidders since on average they bid higher and therefore drive up prices. Similarly, bidders need to learn the auction institution where they are bidding in order to not 
overbid.

Related to experience, in chapter two, we study age and cost-effectiveness in charities. The evidence shows that the older a charity is, the less costeffective it becomes. This shows that, from an organizational perspective, efficiency gains from experience in fundraising do not counteract the negative effects that age brings.

\section{Market behavior}

In chapter four, we focus on market behavior in art auctions and show that exogenous variation related to the private- as well as common-value of an artwork affects different parts of the price distribution. This shows that the population of artworks sold at art auctions is highly heterogeneous and therefore may exhibit different responses to changes in the art market as a whole.

For investors as well as collectors of art it is essential to understand the composition of value of art works offered for sale. Depending on the motives of the potential buyer the variation in the proportions of private and common values may affect the bidder's willingness-to-pay.

\section{Incentives}

In chapter two, variation in the incentive structure of charities, proxied for by their funding structure, affects charitable fundrasing activities significantly. Our study shows that contemporaneously increasing trustees' freedom negatively impacts cost-effectiveness. One year later, part of the lost effectiveness is regained. The net effect is however still negative.

The final chapter looks at the incentives in prediction markets and we show that the absence of monetary incentives results in a different information absorption process compared to when such incentives are present. This casts doubt on the predictive power of prediction markets without the use of proper incentives.

In this spirit, we show that when improper incentives exist in prediction markets the implied probabilities diverge from those in markets where monetary incentives are present. 


\section{References}

Abbring, J. H., Chiappori, P.-A., Heckman, J. J., Pinquet, J., 2003. Adverse selection and moral hazard in insurance: Can dynamic data help to distinguish? Journal of the European Economic Association 1 (2 3), 512-521.

Agarwal, V., Daniel, N. D., Naik, N. Y., 2009. Role of managerial incentives and discretion in hedge fund performance. Journal of Finance 64 (5), $2221-2256$.

Anderoni, J., 1988. Privately provided public goods in a large economy: The limits of altruism. Journal of Public Economics 83 (1), 57-83.

Anderoni, J., 1990. Impure altruism and donations to public goods: A theory of warm-glow giving? Economic Journal 100 (401), 464-477.

Anderoni, J., Payne, A. A., 2003. Do government grants to private charities crowd out giving or fund-raising? American Economic Review 93 (2), 792-812.

Andreoni, J., 1998. Toward a theory of charitable fund-raising. Journal of Political Economy 106 (6), 1186-1213.

Andreoni, J., Payne, A. A., 2011. Is crowding out due entirely to fundraising? evidence from a panel of charities. Journal of Public Economics 95 (5-6), 334-343.

Arrow, K. J., Forsythe, R., Gorham, M., Hahn, R., Hanson, R., Ledyard, J. O., Levmore, S., Litan, R., Milgrom, P., Nelson, F. D., Neuman, G. R., Ottaviani, M., Schelling, T. C., Shiller, R. J., Smith, V. L., Snowberg, E., Sunstein, C. R., Tetlock, P. C., E., T. P., Varian, H. R., Wolfers, J., Zitzewitz, E., 2008. The promise of prediction markets. Science 320 (5878), 877-878.

Ashenfelter, O., 1989. How auctions work for wine and art. Journal of Economic Perspectives 3 (3), 23-36.

Ashenfelter, O., Graddy, K., 2005. Anatomy of the rise and fall of a pricefixing conspiracy: Auctions at sothebyâĂŹs and christieâĂŹs. Journal of Competition Law and Economics 1 (1), 3-20. 
Asker, J., 2010. A study of the internal organisation of a bidding cartel. American Economic Review 100 (3), 724-762.

Bajari, P., Hortaçsu, A., 2003. The winner's curse, reserve prices and endogenous entry: empirical insights from ebay auctions. RAND Journal of Economics 34 (2), 329-355.

Bajari, P., Hortaçsu, A., 2004. Economic insights from internet auctions. Journal of Economic Literature 42 (2), 457-486.

Beggs, A., Graddy, K., 1997a. Declining values and the afternoon effect: Evidence from art auctions. RAND Journal of Economics 28 (3), 544-565.

Beggs, A., Graddy, K., 1997b. Declining values and the afternoon effect: Evidence from art auctions. RAND Journal of Economics 28 (3), 544-565.

Beggs, A., Graddy, K., 2009. Anchoring effects: Evidence from art auctions. American Economic Review 99 (3), 1027-1039.

Berger, P. G., Ofek, E., Yermack, D. L., 1997. Managerial entrenchment and capital structure decisions. Journal of Finance 52 (4), 1411-1438.

Borle, S., Boatwright, P., Kadane, J. B., 2006. The timing of bid placement and extent of multiple bidding: an empirical investigation using eBay online auctions. Statistical Science 21 (2), 194-205.

Bosman, R., Riedl, A., 2004. Emotions and economic shocks in a first-price auction: An experimental study. Mimeo.

Brown, J., Hossain, T., Morgan, J., 2010. Shrouded attributes and information suppression: Evidence from the field. Quarterly Journal of Economics 125 (2), 859-876.

Campbell, J. Y., Perron, P., 1991. Pitfalls and opportunities: What macroeconomists should know about unit roots. NBER Macroeconomics Annual $6,141-220$.

Capra, C. M., Lanier, K. F., Meer, S., 2010. The effects of induced mood on bidding in random nth-price auctions. Journal of Economic Behavior and Organization 75 (2), 223-234.

Carpenter, J., Holmes, J., Matthews, P. H., 2008. Charity auctions: a field experiment. Economic Journal 118 (January), 92-113.

Charities Aid Foundation, 2011. UK Giving 2011. Retrieved on 2012-01-24 from https:/ / www.cafonline.org/pdf/UK_Giving_2011_Full_Rep.pdf.

Charity Commission, 2005. Accounting And Reporting By Charities: Statement Of Recommended Practice. Retrieved on 2011-04-26 from http://www.charitycommission.gov.uk/Library/guidance/sorp05textcolour.pdf. 
Charity Commission, 2012. Facts and Figures, Downloaded June 11, 2012. URL http://www.charitycommission.gov.uk/About_us/About _charities/factfigures.aspx

Chen, K.-Y., Plott, C. R., 2002. Information Aggregation Mechanisms: Concept, Design and Implementation for a Sales Forecasting Problem. California Institute of Technology Social Science Working Paper 1131.

Chiappori, P.-A., Salanié, 2001. Testing contract theory: A survey of some recent work. In: Dewatripont, M., Hansen, L. P., Turnovsky, S. J. (Eds.), Advances in Economics and Econometrics: Theory and Application, Eighth World Congress. Cambridge University Press, pp. 115-149.

Conlin, M., O’Donoghue, T., Vogelsang, T. J., 2007. Projection bias in catalog orders. American Economic Review 97 (4), 1217-1249.

De Silva, D. G., Pownall, R. A. J., Wolk, L., 2012. Does the sun 'shine' on art prices? Journal of Economic Behavior and Organization 82 (1), 167-178.

DellaVigna, S., 2009. Psychology and economics: Evidence from the field. Journal of Economic Literature 47 (2), 315-372.

DellaVigna, S., Malmendier, U., 2004. Contract design and self-control: Theory and evidence. Quarterly Journal of Economics 119 (2), 353-402.

Enders, W., 2004. Applied Econometric Time Series. John Wiley and Sons, New York.

Fahlenbrach, R., Stulz, R. M., 2011. Bank CEO incentives and the credit crisis. Journal of Financial Economics 99 (1), 11-26.

Forsythe, R., Nelson, F., Neumann, G., Wright, J., 1992. Anatomy of an experimental political stock market. American Economic Review 82 (5), 1142-1161.

Frey, B. S., Oberholzer-Gee, F., 1997. The cost of price incentives: An empirical analysis of motivation crowding-out. American Economic Review 87 (4), 746-755.

Giving USA, 2011. Giving USA 2011: The annual report on philanthropy for the year 2010 - Executive Summary. Retrieved on 2012-01-24 from http:/ / www.givingusareports.org.

Gneezy, U., Rustichini, A., 2000. A fine is a price. Journal of Legal Studies $29(1), 1-17$.

Goeree, J. K., Offerman, T., 2003. Competitive bidding in auctions with private and common values. Economic Journal 113 (489), 598-613. 
Goes, P. B., Karuga, G. G., Tripathi, A. K., 2010. Understanding willingnessto-pay formation of repeat bidders in sequential online auctions. Information Systems Research 21 (4), 907-924.

Goetzmann, W. N., 1993. Accounting for taste: Art and the financial markets over three centuries. American Economic Review 83 (5), 1370-1376.

Goetzmann, W. N., Spiegel, M., 1995. Private value components, and the winner's curse in an art index. European Economic Review 39 (3-4), 549555.

Goetzmann, W. N., Zhu, N., 2005. Rain or shine: Where is the weather effect? European Financial Management 11 (5), 559-578.

Graham, P., 2004. Hackers \& Painters: Big ideas from the computer age. O'Reilly Media, Sebastopol, CA.

Guerre, E., Perrigne, I., Vuong, Q., 2000. Optimal nonparametric estimation of first-price auctions. Econometrica 68 (3), 525-574.

Hahn, R. W., Tetlock, P. C., 2006. Information Markets: A New way of making decisions. AEI Press.

Haile, P. A., Hong, H., Shum, M., 2003. Nonparametric tests for common values in first-price sealed-bid auctions. NBER Working Paper 10105.

Härdle, W., 1990. Smoothing techniques: with implementation in S. Springer.

Hauser, D., Wooders, J., 2006. Reputation in auctions: Theory, and evidence from eBay. Journal of Economics \& Management Strategy 15 (2), 353-369.

Hayek, F. A., 1945. The use of knowledge in society. American Economic Review 35 (4), 519-530.

Hirshleifer, D., Shumway, T., 2003. Good day sunshine: Stock returns and the weather. Journal of Finance 58 (3), 1009-1032.

Holmstrom, B., 1979. Moral hazard and observability. Bell Journal of Economics 10 (1), 74-91.

Hossain, T., 2008. Learning by bidding. RAND Journal of Economics 39 (2), 509-529.

Jeitscko, T. D., 1998. Learning in sequential auctions. Southern Economic Journal 65 (1), 98-112.

Jofre-Bonet, M., Pesendorfer, M., 2003. Estimation of a dynamic auction game. Econometrica 71 (5), 1443-1489. 
Johansen, S., 1991. Estimation and hypothesis testing of cointegration vectors in gaussian vector autoregressive models. Econometrica 59 (6), 15511580 .

Johnson, E. J., Tversky, A., 1983. Affect, generalization, and the perception of risk. Journal of Personality and Social Psychology 45 (1), 20-31.

Kamstra, M. J., Kramer, L. A., Levi, M. D., 2003. Winter blues: A SAD stock market cycle. American Economic Review 93 (1), 324-343.

Karlan, D., List, J. A., 2007. Does price matter in charitable giving? evidence from a large-scale natural field experiment. American Economic Review 97 (5), 1774-1793.

Khanna, J., Posnett, J., Sandler, T., 1995. Charity donations in the UK: New evidence based on panel data. Journal of Public Economics 56 (2), 257272.

Kirchkamp, O., Poen, E., Reiß, J. P., 2009. Outside options: Another reason to choose the first-price auctions. European Economic Review 53 (2), 153169.

Kirchkamp, O., Reiß, J. P., 2011. Out-of equilibrium bids in first-price auctions: Wrong expectations or wrong bids. Economic Journal forthcoming.

Kirchsteiger, G., Rigotti, L., Rustichini, A., 2006. Your morals might be your moods. Journal of Economic Behavior and Organization 59 (2), 155-172.

Kiviat, B., 2004. The end of management? Time Magazine, July 12, 2004.

URL http://www.time.com/time/magazine/article/0,9171,994658 , $00 . \mathrm{html}$

Kliger, D., Levy, O., 2003. Mood-induced variation in risk preferences. Journal of Economic Behavior and Organization 52 (4), 573-584.

Koenker, R., Basset, G., 1982. Robust tests for heteroscedasticity based on regression quantiles. Econometrica 50 (1), 43-61.

Kolaczyk, E. D., 2009. Statistical analysis of network data. Springer.

Krishna, V., 2002. Auction Theory. Academic Press.

Kuhnen, C. M., Knutson, B., 2011. The influence of affect on beliefs, preferences and financial decisions. Journal of Financial and Quantitative Analysis forthcoming.

Landry, C. E., Lange, A., List, J. A., Price, M. K., Rupp, N. G., 2006. Toward an understanding of the economics of charity: Evidence from a field experiment. Quarterly Journal of Economics 121 (2), 747-782. 
Lee, Y. H., Malmendier, U., 2010. The bidder's curse. American Economic Review forthcoming.

Leigh, A., Wolfers, J., 2007. Prediction markets for business and public policy. The Melbourne Review 3 (1), 7-15.

Lerner, J. S., Small, D. A., Loewenstein, G., 2004. Heart strings and purse strings: Carryover effects of emotions on economic decisions. Psychological Science 15 (5), 337-341.

List, J., 2003. Does market experience eliminate market anomalies? Quarterly Journal of Economics 118 (1), 41-71.

List, J., 2004. Neoclassical theory versus prospect theory: Evidence from the field. Econometrica 72 (2), 615-625.

Livingston, J. A., 2005. How valuable is a good reputation? A sample selection model of internet auctions. Review of Economics and Statistics 87 (3), 453-465.

Loewenstein, G., O'Donoghue, T., Rabin, M., 2003. Projection bias in predicting future utility. Quarterly Journal of Economics 118 (4), 1209-1248.

Loewenstein, G. F., Hsee, C. K. ., Weber, E. U., Welch, N., 2001. Risk as feelings. Psychological Bulletin 127 (2), 267-286.

Loughran, T., Schultz, P. H., 2004. Weather, stock returns, and the impact of localized trading. Journal of Financial and Quantiative Analysis 39 (2), 343-364.

Majumder, S. R., Diermeier, D., Rietz, T. A., Amaral, L. A., 2009. Price dynamics in political prediction markets. Proceedings of the national academy of sciences 106 (3), 679-684.

Malmendier, U., Szeidl, A., 2008. Fishing for fools. Mimeo.

Mandel, B., 2009. Art as an investment and conspicuous consumption good. American Economic Review 99 (4), 1653-1663.

Marion, J., 2007. Are bid preferences benign? the effect of small business subsidies in highway procurement auctions. Journal of Public Economics 91 (7-8), 1591-1624.

Mei, J., Moses, M., 2002. Art as an investment and the underperformance of masterpieces. American Economic Review 92 (5), 1656-1668.

Mei, J., Moses, M., 2005. Vested interest and biased price estimates: Evidence from an auction market. Journal of Finance 60 (5), 2409-2435. 
Ockenfels, A., Roth, A., 2006. Late and multiple bidding in second-price internet auctions: Theory and evidence concerning different rules for ending an auction. Games and Economic Behavior 55 (2), 297-320.

Okten, C., Weisbrod, B. A., 2000. Determinants of donations in private nonprofit markets. Journal of Public Economics 75 (2), 255-272.

Palfrey, T. R., Prisbrey, J. E., 1997. Anomalous behavior in public goods experiments: How much and why? American Economic Review 87 (5), 829-846.

Peeters, R., Wolk, L., 2012. Incentives in prediction markets. Journal of Prediction Markets 6 (2), 47-58.

Pennock, D. M., Lawrence, S., Giles, C. L., Nielsen, F. A., 2001. The real power of artificial markets. Science 291 (5506), 987.

Posnett, J., Sandler, T., 1989. Demand for charity donations in private nonprofit markets: The case of the U.K. Journal of Public Economics 40 (2), 187-200.

Read, D., 2005. Monetary incentives, what are they good for? Journal of Economic Methodology 12 (2), 265-276.

Reuben, E., van Winden, F., 2008. Social ties and coordination on negative reciprocity: The role of affect. Journal of Public Economics 92 (1-2), 34-53.

Ribar, D. C., Wilhelm, M. O., 2002. Altruistic and joy-of-giving motivations in charitable behavior. Journal of Political Economy 110 (2), 425-457.

Roth, A. E., Ockenfels, A., 2002. Last-minute bidding and the rules for ending second-price auctions: Evidence from ebay and amazon auctions on the internet. American Economic Review 92 (4), 1093-1103.

Rottenstreich, Y., Hsee, C. K., 2001. Money, kisses, and electric shocks: On the affective psychology of risk. Psychological Science 12 (3), 185-190.

Said, M., 2010. Sequential auctions with randomly arriving buyers. Games and Economic Behavior forthcoming.

Saunders, E. M., 1993. Stock prices and wall street weather. American Economic Review 83 (5), 1337-1345.

Seru, A., Shumway, T., Stoffman, N., 2010. Learning by trading. Review of Financial Studies 23 (2), 705-739.

Servan-Schreiber, E., Wolfers, J., Pennock, D. M., Galebach, B., 2004. Prediction markets: Does money matter? Electronic Markets 14 (3), 243-251. 
Silverman, B., 1986. Density Estimation for Statistics and Data Analysis. Chapman \& Hall, London.

Simonsohn, U., Ariely, D., 2008. When rational sellers face nonrational buyers: Evidence from herding on eBay. Management Science 54 (9), 16241637.

Song, U., 2004. Nonparametric estimation of an eBay auction model with unknown number of bidders. Mimeo.

Tetlock, P., 2008. Liquidity and prediction market efficiency. Mimeo.

The Art Wolf, 2011. 101 western painters you should knowRetrieved on 2011-04-20 from http://www.theartwolf.com/articles/most-importantpainters.htm.

Tinkelman, D., 2004. Using nonprofit organization-level financial data to infer managers' fund-raising strategies. Journal of Public Economics 88 (910), 2181-2192.

Wang, X., Hu, Y., 2009. The effect of experience on internet auction bidding dynamics. Marketing Letters 20 (3), 245-261.

Warr, P. G., 1982. Pareto optimal redistribution and private charity. Journal of Public Economics 19 (1), 131-138.

Weisbrod, B. A., Dominguez, N. D., 1986. Demand for collective goods in private nonprofit markets: Can fundraising expenditures help overcome free-rider behavior? Journal of Public Economics 30 (1), 83-95.

Wilcox, R. T., 2000. Experts and amateurs: The role of experience in internet auctions. Marketing Letters 11 (4), 363-374.

Wolfers, J., Zitzewitz, E., 2004. Prediction markets. Journal of Economic Perspectives 18 (2), 107-126.

Zeithammer, R., 2006. Forward-looking bidding in online auctions. Journal of Marketing Research 43 (3), 462-476.

Zeithammer, R., Adams, C., 2010. The sealed-bid abstraction in online auctions. Marketing Science 29 (6), 964-987. 


\section{Nederlandse samenvatting}

Financiële prikkels zijn een belangrijk mechanisme om de belangen van individuen in een markt te behartigen. Contracten en regelgeving kunnen bepaald gedrag stimuleren. In dit proefschrift stellen wij de volgende vragen. Hoe beïnvloeden financiële prikkels het gedrag van individuen? Hoe verandert dit gedrag in verloop van tijd? Hoe beïnvloeden externe factoren het gedrag in de markt? Om deze vragen te beantwoorden presenteren wij vier empirische studies die kort worden samengevat.

In hoofdstuk twee bestuderen we de effecten van de karakteristieken van charitatieve instellingen op het effectief omgaan met gemaakte kosten. Ook kijken we naar het effect van financiële prikkels op de effectiviteit van deze instellingen. Hiervoor gebruiken wij data van de grootste charitatieve instellingen uit het Verenigd Koninkrijk. Wij onderscheiden instellingen met een beperkt en onbeperkt mandaat. Een beperkt mandaat betekent dat contractueel vastgelegd is hoe het goede doel het geld mag besteden, terwijl een onbeperkt fonds vrij is in de besteding van donaties. In het geval van een beperkt mandaat is het onwaarschijnlijk dat het geld ten goede komt aan het fondsmanagement, maar niet wordt gebruikt voor hulp. We laten zien dat veranderingen in het mandaat een grote invloed hebben op het gedrag van charitatieve instellingen. Onze resultaten tonen aan dat asymmetrische informatie tussen de instelling en de donor belangrijk is. Een onbeperkt mandaat leidt ertoe dat de effectiviteit van een instelling op de korte termijn (dit jaar) omlaag gaat. In het volgende jaar is de effectiviteit hoger, maar dit compenseert slechts gedeeltelijk het verlies in het eerste jaar.

In hoofdstuk drie bestuderen we het gedrag van kopers in internetveilingen voor kunst. We bekijken de invloed van ervaring van de koper op het biedgedrag in deze veilingen. Hiervoor gebruiken we een unieke panel dataset uit Zweden. We concluderen dat het biedgedrag veranderd naar mate de ervaring toe neemt. Dit suggereert dat bieders leren van hun 
eerdere biedingen en afwachtend gedrag vertonen. Bieders wachten op mogelijkheden die in latere veilingen worden geboden indien de prijs te hoog is. Dit betekent dat veilinghuizen kunnen profiteren van onervaren bieders. $\mathrm{Zij}$ zijn eerder bereid om meer te betalen dan ervaren bieders.

Hoofdstuk vier bestudeert de waardering en prijzen van kunst in Londen. De waarde van kunst wordt aan de ene kant bepaald door de toekomstige verkoopwaarde (investeringswaarde) en aan de andere kant door de emotionele waarde die het bezit van kunst verschaft. Beide aspecten hebben een belangrijke invloed op de prijs, maar er liggen twee totaal verschillende theorieën aan ten grondslag. De investeringswaarde is te allen tijde gelijk voor alle bieders, omdat het een goed is dat een objectieve maar onbekende waarde heeft (common value). Echter, de emotionele waarde is puur persoonlijk (private value). We scheidden deze twee componenten. Om veranderingen in de emotionele waarde in kaart te brengen, maken we gebruik van veranderingen in het weer. Voor schilderijen met een hoge financiële waarde is er geen effect van emotionele waarde op de prijs. Echter, de emotionele waarde speelt een grote rol voor schilderijen met een lage financiële waarde. Dit betekent dat het voor beleggers in kunst niet alleen belangrijk is om de investeringswaarde te begrijpen, maar dat ze ook rekening moeten houden met de emotionele waarde.

In hoofdstuk vijf bestuderen we het belang van financiële prikkels in voorspellingsmarkten (prediction markets). Een voorbeeld van een voorspellingsmarkt zijn websites waarop mensen de uitkomsten van politieke verkiezingen kunnen voorspellen. De voorspellingen die op deze markten worden gemaakt kunnen worden gebruikt om de uiteindelijke uitkomst te voorspellen. We bestuderen twee voorspellingsmarkten, één voorspellingmarkt waarbij er echt geld op het spel staat en één markt waarbij het om fictief geld gaat. In beide gevallen gaat het om precies dezelfde voorspelling. We vinden bewijs voor manipulatie in deze markten. De managers van de voorspellingswebsites gebruiken informatie uit de markt met echt geld om de prijzen in de markt met fictief geld aan te passen. Desondanks, beweegt één op de vijf voorspellingen verschillend in beide markten. Dit suggereert dat er systematische verschillen zijn in de manier waarop informatie wordt verwerkt. 


\section{Biography}

Leonard Wolk was born on October 9, 1984 in Lund, Sweden. He studied at Jönköping University in Sweden where he graduated with an Ekonomie Kandidatexamen.

He subsequently pursued a Master of Science degree in International Economic Studies, specializing in behavioral economics, at Maastricht University, the Netherlands. After graduating in August 2008, with the thesis "Real- and Play-money in Prediction Markets: A Time Series Approach", he joined the department of Finance at the same university to pursue a doctorate degree.

The result of his effort as a doctoral candidate is collected in this monograph and the work presented herein has been presented at several international conferences including the International Industrial Organization Conference in Boston (2011), the Financial Management Association annual meeting in Denver (2011), and the annual congress of the European Economic Association in Malaga (2012). 